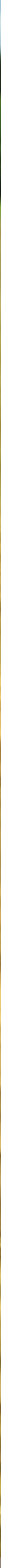

\title{
Verdichting Ondergrond Beter Bodembeheer
}





\section{Verdichting Ondergrond Beter Bodembeheer}

Ir. G. Bakker, Ir. P.E. Dik, Ir. J.J.H. van den Akker, Ing. D.J.M. van Balen

Dit onderzoek is uitgevoerd door Wageningen Environmental Research in het kader van de PPS Beter Bodembeheer.

Wageningen Environmental Research

Wageningen, september 2021

\section{Gereviewd door:}

Ing. D.J.M. van Balen, Onderzoeker bedrijfssystemen en bodem (Wageningen Plant Research) tevens auteur van paragraaf 4.5 en 4.6

Akkoord voor publicatie:

Dr.ir. MJD Hack-ten Broeke, teamleider van Bodem, Water en Landgebruik

Rapport 3109

ISSN 1566-7197 
Ir. G. Bakker, Ir. P.E. Dik, Ir. J.J.H. van den Akker, Ing. D.J.M. van Balen, 2021. Verdichting Ondergrond Beter Bodembeheer. Wageningen, Wageningen Environmental Research, Rapport 3109. 88 blz.; 22 fig.; 27 tab.; 17 ref.

Bodemverdichting, dus zowel de verdichting van de onder- als bovengrond, is een aantasting van de fysische kwaliteit van de bodem en is volgens de Europese Bodemstrategie een van de belangrijkste vormen van bodemdegradatie in Europa. Veel nadelige effecten van bodemverdichting zijn bekend, zoals gereduceerde gewasopbrengsten door nat- en droogteschade en een slechte infiltratie van water. Door een slechte infiltratie van water ontstaat een verhoogd risico op oppervlakkige afspoeling, waardoor ook nutriënten en schadelijke stoffen in grote hoeveelheden versneld in het oppervlaktewater terecht kunnen komen. Ondergrondverdichting, dit is verdichting beneden de bouwvoor, heeft dezelfde nadelige effecten als oppervlakkige bodemverdichting.

Ondergrondverdichting is slecht zichtbaar en daardoor een sluipende oorzaak van problemen.

Bijna $50 \%$ van de Nederlandse landbouwondergronden is verdicht. Ondergrondverdichting lijkt meer problemen te geven door klimaatverandering: de effecten van hogere neerslagintensiteiten en langere droogteperioden worden duidelijker merkbaar. Zware landbouwvoertuigen in natte omstandigheden en het ploegen met één wiel in de bouwvoor zijn over het algemeen de belangrijkste oorzaken van boven- en ondergrondverdichting en structuurverlies van de bodem.

In dit project is op twee proeflocaties met een zand- en zavelbodem onderzocht of door maatregelen de verdichting kan worden beperkt.

De hypothese in voorliggend onderzoek is dat de ondergrondverdichting verminderd kan worden door het gelijktijdig toepassen van twee maatregelen:

1. Gebruik een bodemmanagementsysteem (mechanische bewerking) dat verdichting voorkomt.

2. Laat de bodem zich door de jaren heen op natuurlijke wijze herstellen.

Het werk richt zich op het toetsen van deze hypothese.

In het onderzoek zijn uitgebreide veldmetingen, hydrofysische laboratoriummetingen en SWAPmodelberekeningen uitgevoerd.

Trefwoorden: Bodemverdichting, ondergrondverdichting, onverzadigde zone, hydrofysisch, SWAPmodellering, gewasgroei

Dit rapport is gratis te downloaden van https://doi.org/10.18174/552667 of op www.wur.nl/environmental-research (ga naar 'Wageningen Environmental Research' in de grijze balk onderaan). Wageningen Environmental Research verstrekt geen gedrukte exemplaren van rapporten. 
2021 Wageningen Environmental Research (instituut binnen de rechtspersoon Stichting Wageningen Research), Postbus 47, 6700 AA Wageningen, T 03174807 00,

www.wur.nl/environmental-research. Wageningen Environmental Research is onderdeel van Wageningen University \& Research.

- Overname, verveelvoudiging of openbaarmaking van deze uitgave is toegestaan mits met duidelijke bronvermelding.

- Overname, verveelvoudiging of openbaarmaking is niet toegestaan voor commerciële doeleinden en/of geldelijk gewin.

- Overname, verveelvoudiging of openbaarmaking is niet toegestaan voor die gedeelten van deze uitgave waarvan duidelijk is dat de auteursrechten liggen bij derden en/of zijn voorbehouden.

Wageningen Environmental Research aanvaardt geen aansprakelijkheid voor eventuele schade voortvloeiend uit het gebruik van de resultaten van dit onderzoek of de toepassing van de adviezen.

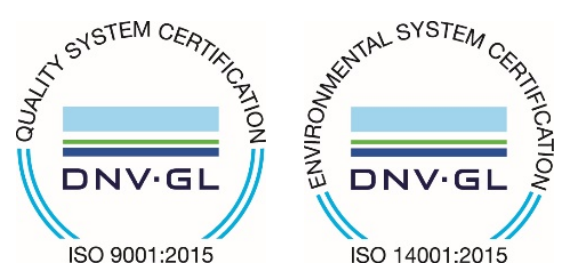

SO 14001:2015

Wageningen Environmental Research werkt sinds 2003 met een ISO 9001 gecertificeerd kwaliteitsmanagementsysteem. In 2006 heeft Wageningen Environmental Research een milieuzorgsysteem geïmplementeerd, gecertificeerd volgens de norm ISO 14001.

Wageningen Environmental Research geeft via ISO 26000 invulling aan haar maatschappelijke verantwoordelijkheid.

Wageningen Environmental Research Rapport 3109 | ISSN 1566-7197

Foto omslag: meetopstelling Lelystad met bodemvochtsensoren in een profielkuil 



\section{Inhoud}

$\begin{array}{ll}\text { Verantwoording } & 7\end{array}$

$\begin{array}{lr}\text { Woord vooraf } & 9\end{array}$

$\begin{array}{ll}\text { Samenvatting } & 11\end{array}$

$1 \quad$ Inleiding

13

1.1 Aanleiding 13

$\begin{array}{lll}1.2 & \text { Doelstelling en vraagstelling } & 13\end{array}$

1.3 Vooronderzoek 14

$\begin{array}{lll}1.4 & \text { Projectafbakening } & 15\end{array}$

$\begin{array}{ll}\text { Methoden } & 16\end{array}$

$2.1 \quad$ Algemene opzet van het onderzoek 16

2.1.1 Directe vergelijking velden 16

2.1.2 Ontwikkelingen in de tijd 16

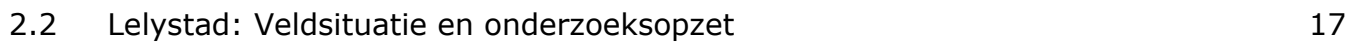

2.2.1 Veldsituatie $\quad 17$

$\begin{array}{ll}2.2 .2 \text { Bedrijfssysteem } & 19\end{array}$

2.2.3 Behandelingen 19

2.2.4 Veldmetingen $\quad 20$

2.3 Vredepeel: Veldsituatie en onderzoeksopzet $\quad 21$

$\begin{array}{ll}2.3 .1 \text { Veldsituatie } & 21\end{array}$

$\begin{array}{ll}2.3 .2 \text { Bedrijfssysteem } & 23\end{array}$

2.3.3 Behandelingen $\quad 23$

$\begin{array}{ll}2.3 .4 \text { Veldmetingen } & 23\end{array}$

$\begin{array}{lll}2.4 & \text { Bodemanalyse hydrofysisch laboratorium } & 24\end{array}$

2.5 Beoordelingswijze hydrofysische bodemanalyses $\quad 24$

$\begin{array}{lll}2.6 & \text { SWAP-modellering } & 25\end{array}$

$3 \quad$ Basisgegevens en Resultaten $\quad 27$

$\begin{array}{lll}3.1 & \text { Lelystad basisgegevens en veldmetingen } & 27\end{array}$

3.1.1 Bodemopbouw en hydrofysische bodemparameters $\quad 27$

3.1.2 Grondwaterstandmetingen $\quad 31$

3.1.3 Neerslag, verdamping en beregening 31

3.1.4 Oppervlaktewaterstanden, buisdrainage en maaiveldafvoer 31

3.1 .5 Geohydrologie $\quad 31$

3.1.6 Geteelde gewassen $\quad 32$

3.1.7 Veldmetingen drukhoogte $\quad 32$

3.1.8 Beworteling en indringweerstand 33

3.1.9 Veldmetingen opbrengsten en beoordeling teelten $\quad 34$

3.2 Vredepeel basisgegevens en veldmetingen 36

3.2.1 Bodemopbouw en hydrofysische bodemparameters 36

3.2.2 Grondwaterstandmetingen (2017-2020) 38

3.2.3 Neerslag, verdamping en beregening 40

3.2.4 Oppervlaktewaterstanden, buisdrainage en maaiveldafvoer $\quad 40$

$\begin{array}{ll}3.2 .5 \text { Geohydrologie } & 40\end{array}$

3.2.6 Geteelde gewassen $\quad 41$

3.2.7 Veldmetingen drukhoogte $\quad 41$

3.2.8 Beworteling en indringweerstand 41

3.2.9 Veldmetingen opbrengsten en beoordeling teelten $\quad 43$ 
3.3 Lelystad SWAP: kalibratie en opbrengsten

3.3.1 Kalibratie en validatie

3.3.2 Grondwaterstanden

3.3.3 Drukhoogte

3.3.4 Beoordeling modellering

3.3.5 Gemodelleerde opbrengsten

3.4 Vredepeel SWAP: kalibratie en opbrengsten $\quad 47$

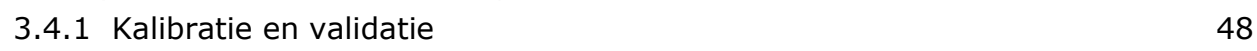

$\begin{array}{ll}3.4 .2 \text { Grondwaterstanden } & 48\end{array}$

$\begin{array}{ll}3.4 .3 \text { Drukhoogte } & 49\end{array}$

3.4.4 Beoordeling modellering 51

3.4.5 Gemodelleerde opbrengsten $\quad 51$

4.1 Beoordeling hydrofysische kenmerken $\quad 52$

4.1.1 Lelystad $\quad 52$

4.1.2 Vredepeel $\quad 55$

4.2 Opbrengsten ploegen versus NKG $\quad 55$

4.2.1 Lelystad $\quad 55$

4.2.2 Vredepeel 56

4.3 Effect en duur langjarig natuurlijk herstel 56

$\begin{array}{lll}4.4 & \text { Effect groenbemesters } & 57\end{array}$

4.4.1 Lelystad $\quad 57$

4.4.2 Vredepeel $\quad 57$

4.5 Uitvoerbaarheid maatregelen $\quad 57$

4.5.1 Lelystad $\quad 57$

4.5.2 Vredepeel $\quad 57$

4.6 Kosten en baten maatregelen $\quad 58$

4.6.1 Lelystad 58

$\begin{array}{ll}4.6 .2 \text { Vredepeel } & 58\end{array}$

$5 \quad$ Conclusie en aanbevelingen $\quad 59$

$\begin{array}{lll}5.1 & \text { Conclusies } & 59\end{array}$

$\begin{array}{lll}5.2 & \text { Aanbevelingen } & 60\end{array}$

$\begin{array}{ll}\text { Literatuur } & 62\end{array}$

$\begin{array}{lll}\text { Bijlage } 1 & \text { Maaiveldhoogte Lelystad } & 64\end{array}$

Bijlage 2 Hydrofysische analysemethoden $\quad 65$

$\begin{array}{lll}\text { Bijlage } 3 & \text { Meteogegevens Lelystad } & 69\end{array}$

$\begin{array}{lll}\text { Bijlage } 4 \quad \text { Lithologie Lelystad } & 71\end{array}$

Bijlage 5 Onderdruk Lelystad $\quad 72$

$\begin{array}{lll}\text { Bijlage } 6 & \text { Indringweerstanden Lelystad } & 73\end{array}$

$\begin{array}{lll}\text { Bijlage } 7 & \text { Bodemprofielen Vredepeel } & 75\end{array}$

$\begin{array}{lll}\text { Bijlage } 8 & \text { Neerslaggegevens Vredepeel } & 76\end{array}$

$\begin{array}{lll}\text { Bijlage } 9 & \text { Lithologie Vredepeel } & 78\end{array}$

Bijlage 10 Gewasontwikkeling Groenmonitor Vredepeel $\quad 79$

Bijlage 11 Metingen tensiometers Vredepeel $\quad 82$

$\begin{array}{lll}\text { Bijlage } 12 \text { Opbrengsten Vredepeel } & 84\end{array}$

$\begin{array}{lll}\text { Bijlage } 13 \text { SWAP-modelcheck Lelystad } & 86\end{array}$ 


\section{Verantwoording}

Rapport: 3109

Projectnummer: 5200046317

Wageningen Environmental Research (WENR) hecht grote waarde aan de kwaliteit van zijn eindproducten. Een review van de rapporten op wetenschappelijke kwaliteit door een referent maakt standaard onderdeel uit van ons kwaliteitsbeleid.

De referent van dit rapport, Derk van Balen, heeft naast een review van het gehele rapport tevens paragraaf 4.5 'Uitvoerbaarheid maatregelen' en 4.6 'Kosten en baten maatregelen' geschreven: een waardevolle aanvulling op de formele onderzoeksvraag. Daarom is hij ook als medeauteur opgenomen.

Akkoord Referent die het rapport heeft beoordeeld,

functie: Onderzoeker bedrijfssystemen en bodem (Wageningen Plant Research)

naam: $\quad$ Ing. D.J.M. van Balen

datum: 20-7-2021

Akkoord teamleider voor de inhoud,

naam: Dr.ir. M.J.D. Hack-ten Broeke

datum: $\quad$ 18-08-2021 


\section{Woord vooraf}

Dit onderzoek naar het effect van ondergrondverdichting op gewasopbrengsten is onderdeel van het project 'PPS Beter Bodembeheer' waarbinnen verschillende thema's zijn gedefinieerd. Een van de thema's is het thema Verdichting Ondergrond, ondergebracht in werkpakket WP6 en dit rapport, waarin methoden en maatregelen worden ontwikkeld voor het opheffen of voorkomen van ondergrondverdichting. Andere thema's binnen dit project zijn Organische Stof en bemesting (WP1 en WP2), Nuttig bodemleven en beheersing bodempathogenen (WP3), Gewas-bodem-interacties; groenbemesterkeuze in tijd en ruimte (WP4), Bodemconserverende grondbewerking (WP5), Ondergrondse en bovengrondse interacties: weerbare productiesystemen (WP7), Meten van Bodemkwaliteit en Bodemkwaliteitsinstrumenten (WP8 en WP9), Communicatie en Coördinatie (WP10).

Een Publiek-Private Samenwerking (PPS) is een samenwerkingsvorm tussen een overheid en een of meer private ondernemingen. Het PPS Beter Bodembeheer is gefinancierd door het ministerie van Landbouw, Natuurbeheer en Voedselkwaliteit (LNV), tezamen met een consortium van verschillende partijen uit de plantaardige productieketen met als penvoerder de Brancheorganisatie Akkerbouw. De PPS is onderdeel van de Topsector Agri \& Food. Zonder alle betrokkenen bij naam te noemen, willen wij hen en de leden van de stuurgroep bedanken voor hun inbreng en bijdragen.

Gerben Bakker, Pim Dik, Jan van den Akker, Derk van Balen 


\section{Samenvatting}

Bodemverdichting, dus zowel de verdichting van de onder- als bovengrond, is een aantasting van de fysische kwaliteit van de bodem en is volgens de Europese Bodemstrategie een van de belangrijkste vormen van bodemdegradatie in Europa. Voorliggend onderzoek richt zich op ondergrondverdichting.

Ondergrondverdichting heeft veel nadelige effecten, zoals gereduceerde gewasopbrengsten. Gewasgroeireductie door ondergrondverdichting treedt op als water bij droogte moeilijk via capillaire nalevering vanuit de ondergrond door de verdichte laag naar de wortels kan worden getransporteerd. Wortels op hun beurt zijn niet in staat om door de verdichte laag heen te dringen om water uit de meestal vochtigere - ondergrond op te nemen. Bij hevige regenbuien kan het water onvoldoende snel afgevoerd worden naar de ondergrond, waardoor eveneens gewasschade ontstaat, maar nu door natschade als gevolg van stagnerend water. Omdat momenteel $50 \%$ van de Nederlandse ondergronden al te dicht zijn, proberen we binnen dit thema te komen tot een set van herstellende maatregelen.

De hypothese in voorliggend onderzoek is dat de ondergrondverdichting verminderd kan worden door het gelijktijdig toepassen van twee maatregelen:

1. Gebruik een bodemmanagementsysteem (mechanische bewerking) dat verdichting voorkomt, én

2. Laat de bodem zich door de jaren heen op natuurlijke wijze herstellen.

Om de hypothese te toetsen, zijn veldmetingen uitgevoerd op een typische zavelgrond (Lelystad) en zandgrond (Vredepeel) en zijn de hydrofysische verschillen in de bodem gemeten in het laboratorium alsook in het veld op zowel een plot met ploegen als een plot met niet-kerende grondbewerking (NKG). De meetgegevens zijn ook gebruikt om van de plots simulatiemodellen (SWAP) te maken. In tegenstelling tot de praktijkmetingen kunnen in het model indirecte effecten zo veel mogelijk worden geëlimineerd en kunnen de effecten van de hydrofysica in de bodem op de gewasopbrengst in engere zin worden bestudeerd. De modellen zijn voor de meetperiode gekalibreerd met de veldgegevens.

Ad1: Er zijn in dit onderzoek geen duidelijke aanwijzingen dat ondergrondverdichting door NKG in vergelijking met ploegen is verminderd.

Ad 2: In de loop van de tijd zijn in de wortelzone en/of ondergrond veranderingen opgetreden, hetgeen blijkt uit de toename van de opbrengsten bij NKG in de tijd. Mogelijke verklarende veranderingen zijn bodemleven, netwerk van macroporiën en beschikbaarheid van nutriënten.

Toelichting:

- De fysische kwaliteit (zoals het poriënvolume, de dichtheid, de verzadigde waterdoorlatendheid, het luchtgehalte en de indringingsweerstand) van de ondergrond direct onder de bewerkingsdiepte is bij NKG op een aantal punten duidelijk slechter dan bij ploegen. Dit geldt voor zowel de locatie Lelystad (zavelgrond) als de locatie Vredepeel (zandgrond). Dit is een resultaat dat niet voor de hand ligt, maar wel is te verklaren.

- De modelsimulatie met SWAP geeft bij ploegen voor beide locaties in beperkte mate een iets hogere, maar niet significant grotere opbrengst in droge jaren dan bij NKG. Deze simulatie is uitgevoerd met de gemeten hydrofysische parameters als invoer en gegevens omtrent bewortelingsdiepte en/of bewortelbaarheid.

- De gemeten opbrengsten laten zien dat de opbrengsten van NKG weliswaar in de jaren toeneemt, maar dat het pas na een jaar of zeven vergelijkbare opbrengsten geeft als ploegen.

- De spreiding in de resultaten en de onzekerheid in de variabelen zijn vanwege de beperkte omvang van het onderzoek aanzienlijk. De hypothese kan daarom niet aangenomen, maar ook niet verworpen worden: het onderzoek geeft onvoldoende significant bewijs voor het effect van de maatregelen. 
Een onderzoek en proef zoals die in voorliggend rapport zijn beschreven, zijn complex en kunnen vele variabelen bevatten die van invloed zijn op de resultaten. Een beperkt onderzoek zoals dit laat zien dat het geen harde wet is die pleit voor NKG of regulier ploegen. Het toont aan dat ploegen met een wiel in de bouwvoor niet automatisch leidt tot meer ondergrondverdichting dan NKG. Het is zelfs zo dat NKG hier slechter presteert dan ploegen. Een belangrijke conclusie is echter ook dat het onderzoek te beperkt van opzet is om harde, statistisch significante conclusies te kunnen trekken.

Omdat een totaalbeeld van relevante parameters in voldoende herhalingen in ruimte en tijd onderzoekstechnisch een stuk efficiënter is dan vele kleine onderzoeken, pleiten de onderzoekers ervoor om krachten te bundelen in een groot onderzoek naar ondergrondverdichting, zodat wel sluitende uitspraken gedaan kunnen worden. Uitgebreide metingen van alle hydrofysische bodemkwaliteiten, opbrengsten en randvoorwaarden in de tijd zijn weliswaar kostbaar, maar erg waardevol. De praktijk heeft grote behoefte aan het kunnen maken van gefundeerde keuzen voor managementopties. 


\section{$1 \quad$ Inleiding}

Binnen het project Beter Bodembeheer zijn verschillende thema's gedefinieerd. Een van de thema's is het thema Verdichting Ondergrond, waarin methoden en maatregelen worden ontwikkeld voor het opheffen of voorkomen van ondergrondverdichting. Er wordt gekeken naar de effecten van typen mechanische grondbewerkingen, maar ook naar de effecten van natuurlijke bewerkingen, zoals het toepassen van diep wortelende gewassen en naar natuurlijk herstel door verdroging, vernatting en vorst. Dit rapport gaat over de effecten van verschillende mechanische bewerkingen en het gedrag van de bodem daarin in de tijd.

\section{$1.1 \quad$ Aanleiding}

Bodemverdichting, dus ook de verdichting van de bovengrond, is een aantasting van de fysische kwaliteit van de bodem en is volgens de Europese Bodemstrategie een van de belangrijkste vormen van bodemdegradatie in Europa. Het vormt daarmee een belangrijk onderdeel binnen het overkoepelende thema Bodemgezondheid (Eng: Soil Health). Veel nadelige effecten van bodemverdichting zijn bekend, zoals gereduceerde gewasopbrengsten door nat- en droogteschade, door een slechte infiltratie van water en een beperkte bewortelingsdiepte. Door een slechte infiltratie van water ontstaat een verhoogd risico op oppervlakkige afspoeling, waardoor nutriënten en schadelijke stoffen in grote hoeveelheden versneld in het oppervlaktewater terecht kunnen komen.

Bijna 50\% van de Nederlandse landbouwondergronden is verdicht. Ondergrondverdichting lijkt meer problemen te geven door klimaatverandering: de effecten van hogere neerslagintensiteiten en langere droogteperioden worden duidelijker merkbaar. Zware landbouwvoertuigen in natte omstandigheden en het ploegen met één wiel in de bouwvoor zijn over het algemeen de belangrijkste oorzaken van boven- en ondergrondverdichting en structuurverlies van de bodem.

Het wrange binnen dit thema is dat ondergrondverdichting, dus verdichting beneden de bouwvoor, moeilijk is te herstellen. Het algemene devies is daarom nog steeds dat voorkomen veel beter is dan genezen. Echter, omdat momenteel $50 \%$ van de Nederlandse ondergronden al te dicht is, proberen we binnen dit thema te komen tot een set van herstellende maatregelen.

\subsection{Doelstelling en vraagstelling}

De hypothese in dit onderzoek is dat de ondergrondverdichting verminderd kan worden door het gelijktijdig toepassen van twee maatregelen:

1. een bodemmanagementsysteem (mechanische bewerking) dat verdichting voorkomt, én

2. de bodem zich door de jaren heen op natuurlijke wijze te laten herstellen.

Aanvullend wordt getracht een antwoord te geven op de volgende drie vragen:

1. Hoe eenvoudig zijn de maatregelen uit te voeren?

2. Wat zijn de kosten/baten van de verschillende bewerkingen?

3. Na hoeveel jaar kunnen effecten verwacht worden?

Het onderzoek is onderdeel van een langjarig onderzoek, waar de effecten van niet-kerende grondbewerking (NKG) vergeleken zijn met ploegen. Dit is gedaan in zowel een gangbare als biologische vruchtwisseling op een zavelgrond in Lelystad en een zandgrond in Vredepeel. De zavelondergrond in Lelystad heeft door krimp en zwel een potentieel natuurlijk herstel, waardoor ook biologische herstelprocessen effectiever kunnen worden. De zandondergrond in Vredepeel heeft geen krimp- en zweleigenschappen, waardoor natuurlijk herstel volledig afhangt van biologische processen. 
In het onderzoek zijn uitgebreide veldmetingen, hydrofysische laboratoriummetingen en SWAPmodelberekeningen uitgevoerd. Dit thema heeft qua inhoud en experimenteel werk sterke connecties met andere thema's binnen het Beter Bodembeheer-project, maar ook met externe projecten.

Ad Maatregel 1: een bodemmanagementsysteem (mechanische bewerking) dat verdichting voorkomt. Op beide locaties is zowel een niet-kerende grondbewerking (ondiep cultiveren) en een kerende grondbewerking (ploegen) onderzocht. Tijdens het ploegen wordt in de open voor gereden. ${ }^{1}$

Ad Maatregel 2: de bodem herstelt zich door de jaren heen op natuurlijke wijze.

Op beide locaties is onderzocht in hoeverre de hydrofysische bodemeigenschappen verschillen na meer dan acht jaar verschillend bodemmanagement. Hydrofysische eigenschappen zijn bijvoorbeeld de doorlatendheid voor water en zuurstof, het watervasthoudend vermogen of de bodemdichtheid. Een kleinere bodemdichtheid maakt diepe wortelgroei mogelijk waardoor water niet alleen vanuit de bovengrond, maar ook op grotere diepte op te nemen is. Hierdoor neemt de kans op groeiachterstand bij droog weer af. Diepe wortelgroei (door het doelgewas) dan wel door een groenbemester, is onderdeel van het natuurlijk herstelvermogen van een ondergrond. De gewas-opbrengstgegevens zijn alle jaren in het overkoepelende langjarige Beter Bodembeheer-project gemeten.

De verwachting is overigens dat een eventueel natuurlijk bodemherstel het zichtbaarst is op de zavelgrond door het zwellen en krimpen bij verschillende vochttoestanden, of door vorst. ${ }^{2}$

\subsection{Vooronderzoek}

In 2009 is het onderzoek BASIS gestart waarbij de effecten van niet-kerende grondbewerking (NKG) vergeleken zijn met ploegen in zowel een gangbare als biologische vruchtwisseling. In de proef is gebruik gemaakt van rijpaden. De toegepaste grondbewerkingen zijn (1) ploegen tot een diepte van 22-25 cm, waarbij in de open voor wordt gereden, (2) NKG met tot $20 \mathrm{~cm}$ diepte cultiveren na de oogst (Lelystad) of in het voorjaar (Vredepeel), (3) NKG zonder cultiveren met rijbanenteelt (Controlled Traffic Farming (CTF)), (4) ondiep ploegen/ecoploeg waarbij niet in de open voor wordt gereden (bovenover ploegen), ploegdiepte 10-15 cm (sinds 2018). De resultaten zijn weergegeven in De Haan et al., 2017 (Vredepeel biologisch), Hoek et al., 2019 (Lelystad) en Crittenden, 2015.

Het effect van grondbewerking op de opbrengst, maar ook op hydrofysische, chemische en biologische eigenschappen is onderzocht. De monitoring van bodemverdichting (in de tijd) is, in tegenstelling tot de momentane eigenschappen, beperkt gebleven tot het meten van indringingsweerstanden. De duidelijkste langdurige effecten van bodemverdichting zijn te verwachten in de ondergrond. De ploegzool is daarbij het bovenste en meest verdichte deel van de ondergrond. De onderste $10 \mathrm{~cm}$ van de bouwvoor krijgt bij NKG door het niet losmaken op den duur naar verwachting een duidelijke eigen structuur.

In de projectperiode van het project BASIS is beperkt ingegaan op het effect van rijpadenteelt en nietkerende grondbewerking op ondergrondverdichting (https://www.beterbodembeheer.nl/nl/beterbodembeheer/Publicaties/Verdichting-ondergrond.htm en Bastiaansen, 2019).

\footnotetext{
1 Voorafgaand aan de langjarige proeven van dit onderzoek is tot onder de bouwvoor gewoeld om eventueel bestaande ploegzolen op te heffen. Op deze wijze hebben zowel de plots met een niet-kerende grondbewerking als de plots met een kerende grondbewerking eenzelfde start wat betreft ondergrondverdichting.

2 Vanwege de beperkte omvang van het project konden de hydrofysische eigenschappen slechts één keer aan het einde van het experiment worden gemeten. Er is dus geen directe relatie te leggen tussen de ontwikkeling van de hydrofysische bodemeigenschappen in de tijd en de opbrengstgegevens.
} 


\section{$1.4 \quad$ Projectafbakening}

Om een goed antwoord op de hypothese en aanvullende vragen te kunnen geven, zijn meerdere herhalingen nodig en moeten verschillende gronden worden onderzocht. Voorliggend onderzoek richt zich voornamelijk op het meten en modelleren van de hydrofysische bodemeffecten in de systeemexperimenten zonder herhaling: op een zavelgrond in Lelystad en op een zandgrond in Vredepeel. Via 1D-SWAP-modellering en toetsing daarvan aan meetgegevens in het veld wordt nagegaan in hoeverre de verschillen in hydrofysische bodemeigenschappen bij verschillend bodemmanagement doorwerken in de hydrologie en de gewasgroei. 


\section{Methoden}

\subsection{Algemene opzet van het onderzoek}

Op een typische zavelgrond (Lelystad) en zandgrond (Vredepeel) zijn voor elke locatie, zowel een plot met ploegen als een plot met NKG, de volgende onderdelen onderzocht:

1. Beoordeling bodemsoort en bodemopbouw

2. Hydrologie

3. Meteocondities

4. Monitoring/veldmetingen van bodemvochtpotentialen in de verschillende bodemhorizonten

5. Meting van indringweerstanden en grondwaterstanden

6. Monstername van de verschillende bodemhorizonten voor laboratoriumanalyses

7. Hydrofysische laboratoriumbepalingen en de rechtstreekse beoordeling daarvan

8. Combineren van de verkregen informatie in een SWAP-model om grip te krijgen op de oorzaak en het gevolg van de verschillende gegevens op de effecten van de bewerkingen

\subsubsection{Directe vergelijking velden}

Door de velden met de verschillende bewerkingen op de plots en locaties direct met elkaar te vergelijken, ofwel door de vraag te stellen welk veld het beter doet, wordt impliciet aangenomen dat de velden in de beginsituatie in dezelfde conditie waren en dat de randvoorwaarden voor de beide velden dezelfde zijn (meteo, oppervlaktewaterstanden, ontwateringssituatie etc.). Uiteraard is dat voor veldproeven nooit helemaal het geval. Toch wordt getracht een vergelijking te maken en zullen de onzekerheden worden aangegeven.

\subsubsection{Ontwikkelingen in de tijd}

Door de ontwikkelingen op een plot in de tijd te bekijken, kan een oordeel gevormd worden of de prestatie-index in de tijd toeneemt. Ook voor de ontwikkeling van een prestatie-index in de tijd kan een oordeel worden gevormd.

De verwachting is dat NKG in de tijd tot een verminderde ondergrondverdichting leidt dan ploegen. Om deze vragen goed te kunnen beantwoorden, moeten er voldoende meetgegevens aanwezig zijn. Dit is mogelijk het geval voor de indringweerstand, organisch stof en de opbrengsten, omdat deze langjarig zijn gemonitord. Bepaalde randvoorwaarden kunnen in de tijd echter sterk variëren, zoals meteorologie, ziekten en plagen en onkruiddruk, maar ook de hydrofysica van de bodem. Dit kan een vergelijk lastig maken.

Voor de beoordeling zijn de volgende grootheden gemeten of afgeleid:

- Beworteling

- Hydrofysica over de diepte tot de grondwaterstand

- Indringweerstand (sterk afhankelijk van de vochtcondities)

- Bulkdichtheid

- Waterretentiekarakteristiek

- Waterdoorlatendheidskarakteristiek

- Luchtgevulde poriën

- Poriënvolume totaal

- Kritieke z-afstand

- Gewasopbrengsten 
De samenhang tussen de verschillende grootheden zijn onderzocht met een 1D-SWAP-simulatiemodel, waarbij gekeken wordt naar de:

- Berekende grondwaterstanden en bodemvocht

- Berekende actuele transpiratie

- Berekende gewasopbrengsten

- Toetsing met de in de praktijk gemeten eigenschappen

\subsection{Lelystad: Veldsituatie en onderzoeksopzet}

\subsubsection{Veldsituatie}

In Tabel 2.1 is de bewerking per Veld-Blok-Bed weergegeven.

Tabel 2.1 Overzicht bewerkingen per Veld-Blok-Bed Lelystad.

\begin{tabular}{lllll} 
Veld & Blok & Bed & Afkorting bewerking & Omschrijving bewerking \\
\hline 4 & 1 & 1 & Ploeg15* & ondiep ploegen tot $10-15 \mathrm{~cm}$ \\
\hline 4 & 3 & 12 & NKG20 & NKG+cultiveren tot maximaal $20 \mathrm{~cm}$ \\
\hline 6 & 14 & 66 & NKG0 & NKG zonder cultiveren \\
\hline 6 & 16 & 76 & Ploeg25 & Normaal ploegen tot $25 \mathrm{~cm}$ \\
\hline
\end{tabular}

*) Voorheen was dit een NKG0-object.

In Figuur 2.1 is de indeling van het perceel J9GI met de in grijs gearceerde onderzochte velden gegeven.

\begin{tabular}{|c|c|}
\multicolumn{1}{|c|}{ J9 Gl } & J10 BIO \\
\hline 6 & 6 \\
\hline 5 & 5 \\
\hline 4 & 4 \\
\hline \multicolumn{2}{|c|}{ kavelpad } \\
\hline 3 & 3 \\
\hline & 2 \\
\cline { 2 - 2 } & 1 \\
\cline { 2 - 2 } &
\end{tabular}

Figuur 2.1 Ligging velden $1 \mathrm{t} / \mathrm{m} 6$ bij verschillende behandelingen (GI: geïntegreerd, BIO: biologisch). Grijs: de geanalyseerde velden. 


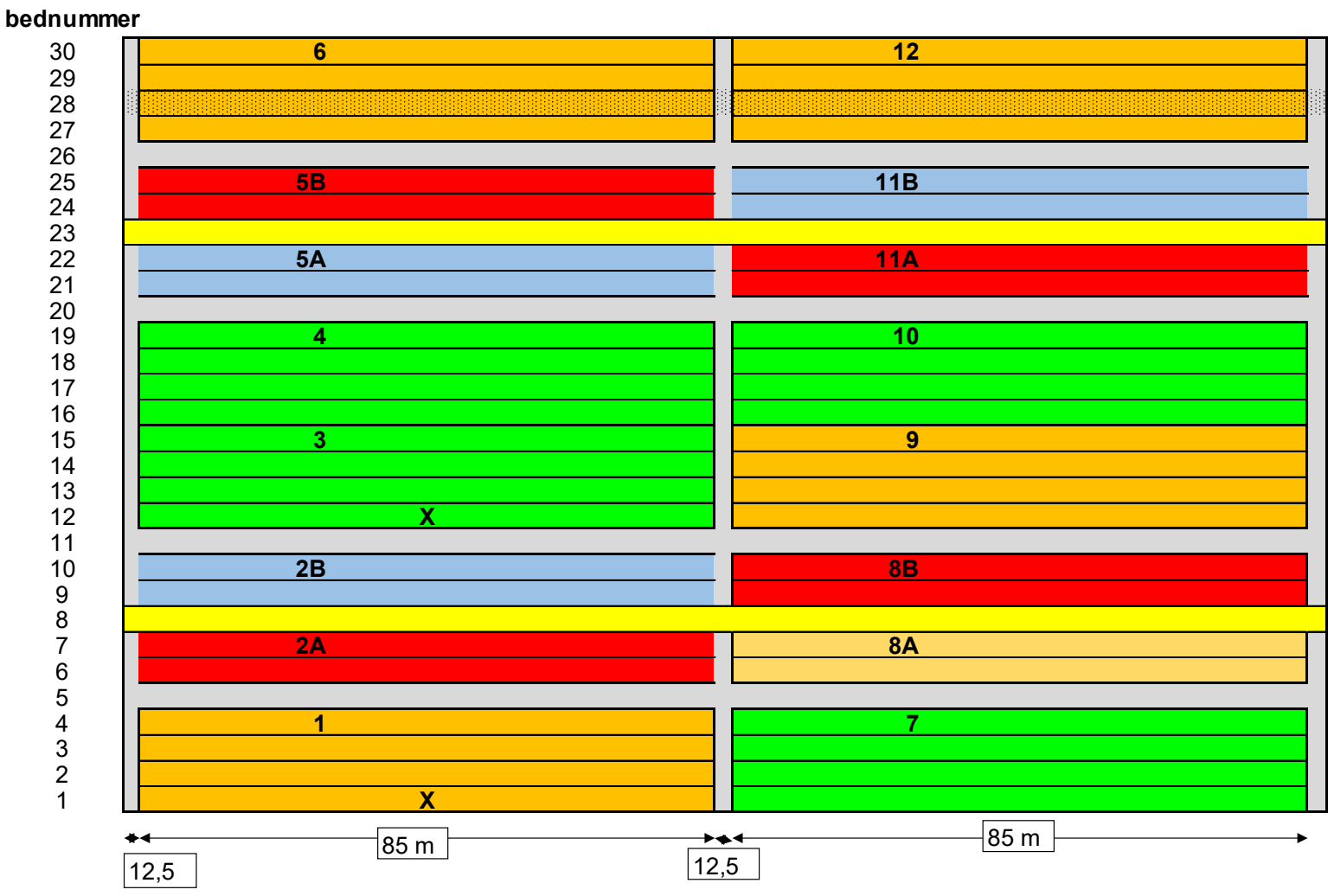

Figuur 2.2 Indeling veld 4 (perceel J9GI) met de bednummers en de bloknummers. De bedden met vaste rijpaden zijn 3,15 $\mathrm{m}$ breed (netto $3 \mathrm{~m}$ ). Elk veld is 12,60 m breed. De grijze vlakken zijn bufferstroken (horizontaal 3,15 m, verticaal $6 \mathrm{~m}$ (kopakker) of $12 \mathrm{~m}$ (interne kopakker).

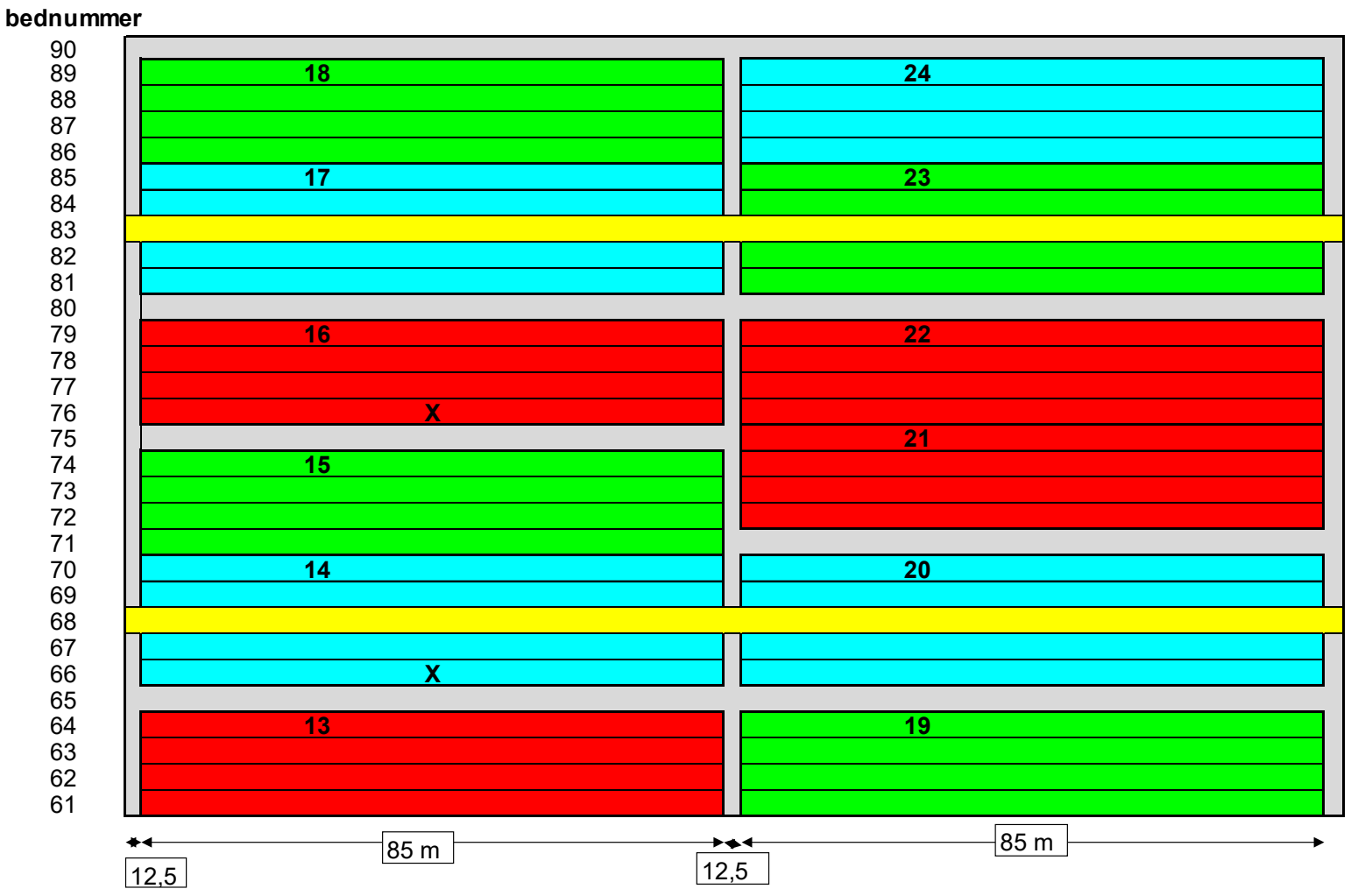

Figuur 2.3 Indeling veld 6 (perceel J9GI) met de bednummers en de bloknummers. De bedden met vaste rijpaden zijn 3,15 $\mathrm{m}$ breed (netto $3 \mathrm{~m}$ ). Elk veld is 12,60 m breed. De grijze vlakken zijn bufferstroken (horizontaal 3,15 m, verticaal $6 \mathrm{~m}$ (kopakker) of $12 \mathrm{~m}$ (interne kopakker). 
In Bijlage 1 is een figuur van de maaiveldhoogten gegeven. Tabel $2.2 \mathrm{geeft}$ een overzicht van de verschillende behandelingen.

Tabel 2.2 Overzicht behandelingen (perceel J9GI, veld 4 en 6).

\begin{tabular}{lllll} 
Locatie & Codering & Beschrijving & Periode & Opmerking \\
Veld 4 Blok 3 Bed 12 & T & NKG20 & Vanaf 2009 & \\
\hline Veld 4 Blok 1 Bed 1 & Spo & Ploeg15 & Vanaf 2018 & ploegdiepte ca 10-15 cm \\
\hline Veld 6 Blok 16 Bed 76 & ST & Ploeg25 & Vanaf 2009 & Ap wat dikker, geploegd land, stro ondergewerkt \\
\hline Veld 6 Blok 14 Bed 66 & M & NKG20 & Vanaf 2009 & deels zandige ondergrond, stoppels graan \\
\hline
\end{tabular}

\subsubsection{Bedrijfssysteem}

In 2009 is in Lelystad het onderzoek BASIS gestart waarbij de effecten van niet-kerende grondbewerking (NKG) vergeleken zijn met ploegen in twee vruchtwisselingssystemen:

\section{Gangbaar bedrijfssysteem}

- Vruchtwisseling: Pootaardappel-suikerbiet-zomergerst-zaaiui (1 op 8 zaaiuien en 1 op 8 conservenerwt). In februari 2018 is het object ondiep ploegen op J9-4 $16 \mathrm{~cm}$ diep geploegd.

- Bemesting: Geen organische bemesting. Wel deelproef met toepassen van compost en wel of niet groenbemester.

- Onkruidbestrijding: er wordt over het algemeen gebruikgemaakt van vorstgevoelige groenbemesters om het gebruik van glyfosaat te voorkomen. Glyfosaat is toch toegepast in de afgelopen jaren vanwege hoge onkruiddruk in het voorjaar, maar ook om niet-bevroren groenbemesters dood te spuiten.

\section{Biologisch bedrijfssysteem}

- Vruchtwisseling: Consumptieaardappel-grasklaver-kool-zomertarwe-peenstamslaboon/zomertarwe.

- Bemesting: Biologische vaste rundveemest in het najaar, rundveedrijfmest in het voorjaar, incidenteel (kippen)mestkorrels.

- Zaai-, plant- en pootbedbereiding zijn zo veel mogelijk gelijk gehouden tussen de systemen. In een enkel geval is hiervan afgeweken, zoals het frezen van de peenruggen.

- Onkruidbestrijding: Er is weinig onderscheid in onkruidbestrijding (mechanisch en handmatig) in de verschillende grondbewerkingssystemen.

\subsubsection{Behandelingen}

In de proef is gebruikgemaakt van vaste rijpaden, oftewel onbereden teeltbedden. De behandelingen zijn gestart in 2009 en lopen door tot op heden:

\section{- Ploegen (Ploeg25):}

Hierbij wordt er geploegd met een traditionele ploeg op een diepte van 22-25 cm. In de akkerbouwpraktijk in Flevoland is er een tendens naar ondieper ploegen waarbij de ploegdiepte afhangt van de uitgangssituatie van het perceel. Zo zal de bodemgesteldheid (vlakligging) als de mate van onderwerken van gewasresten of groenbemester bepalend zijn voor de uiteindelijke ploegdiepte. Er wordt gewerkt met een 4-schaar wentelploeg die in de voor rijdt. Wanneer nodig worden voorscharen gebruikt.

\section{- Niet-kerende grondbewerking met cultivator (NKG20):}

De grond wordt zodanig bewerkt dat er een goed zaai- of pootbed gemaakt kan worden. Na de oogst van een gewas worden de compacte bodemlagen doorbroken met een bouwvoorlichter (in dit geval een paragruber type). Akkerbouwers die werken met niet-kerende grondbewerking werken eveneens met dit systeem. De diepte van losmaken wordt bepaald aan de hand van onderzoek in het veld. Deze bewerking gaat tot maximaal $20 \mathrm{~cm}$. Deze bewerking wordt achterwege gelaten wanneer er geen noodzaak is tot het opheffen van storende lagen of wanneer de bodemgesteldheid dit niet toelaat (bv. te nat).

\section{- Ondiep ploegen (Ploeg15):}

Ondiep ploegen (ecoploegen, tot een diepte van 10-15 cm) staat als vorm van gereduceerde grondbewerking in de belangstelling. Dit systeem biedt voordelen, omdat er 'bovenover' geploegd 
wordt, waardoor er minder kans is op de vorming van een ploegzool. Bij ondiep ploegen blijft ook meer organische stof in de toplaag en daarmee de kans dat er stikstof in het systeem behouden blijft. Ondiep ploegen kan de voordelen van ploegen, zoals onkruidbeheersing, bedrijfshygiëne en zaaibedbereiding, mogelijk combineren met die van NKG: opbouw organische stof in toplaag, vochten stikstofhuishouding. Ondiep ploegen vindt in Lelystad één keer per acht jaar plaats (voor de zaaiuien uit).

\section{- Niet-kerende grondbewerking zonder cultiveren (NKG0):}

Aangezien er met vaste rijpaden gewerkt wordt (Controlled Traffic Farming (CTF)), is er geen kans op bodemverdichting door berijding en storende lagen. Echter, de oogstmechanisatie is niet volledig aangepast aan dit systeem en soms is het nodig om storende lagen op te heffen om te zorgen voor voldoende gewasgroei (en -opbrengst). Na de oogst van peen in het biologisch teeltsysteem is het noodzakelijk gebleken een dergelijke bewerking uit te voeren.

\subsubsection{Veldmetingen}

In april 2019 zijn er profielbeschrijvingen gemaakt van de vier plots, zijn er gericht bodemmonsters genomen uit meerdere bodemhorizonten voor analyse in het bodemhydrofysisch laboratorium en zijn in het veld tensiometers geplaatst in de verschillende bodemhorizonten om de vochtcondities gedurende een groeiseizoen te kunnen monitoren. Deze gegevens zijn gebruikt ter validatie van het 1D-SWAP model.

De metingen zijn (alleen) in april 2019 uitgevoerd. 


\subsection{Vredepeel: Veldsituatie en onderzoeksopzet}

\subsubsection{Veldsituatie}

De locatie ligt op de grens van Brabant en Limburg tussen Venray en Helmond (Figuur 2.4).

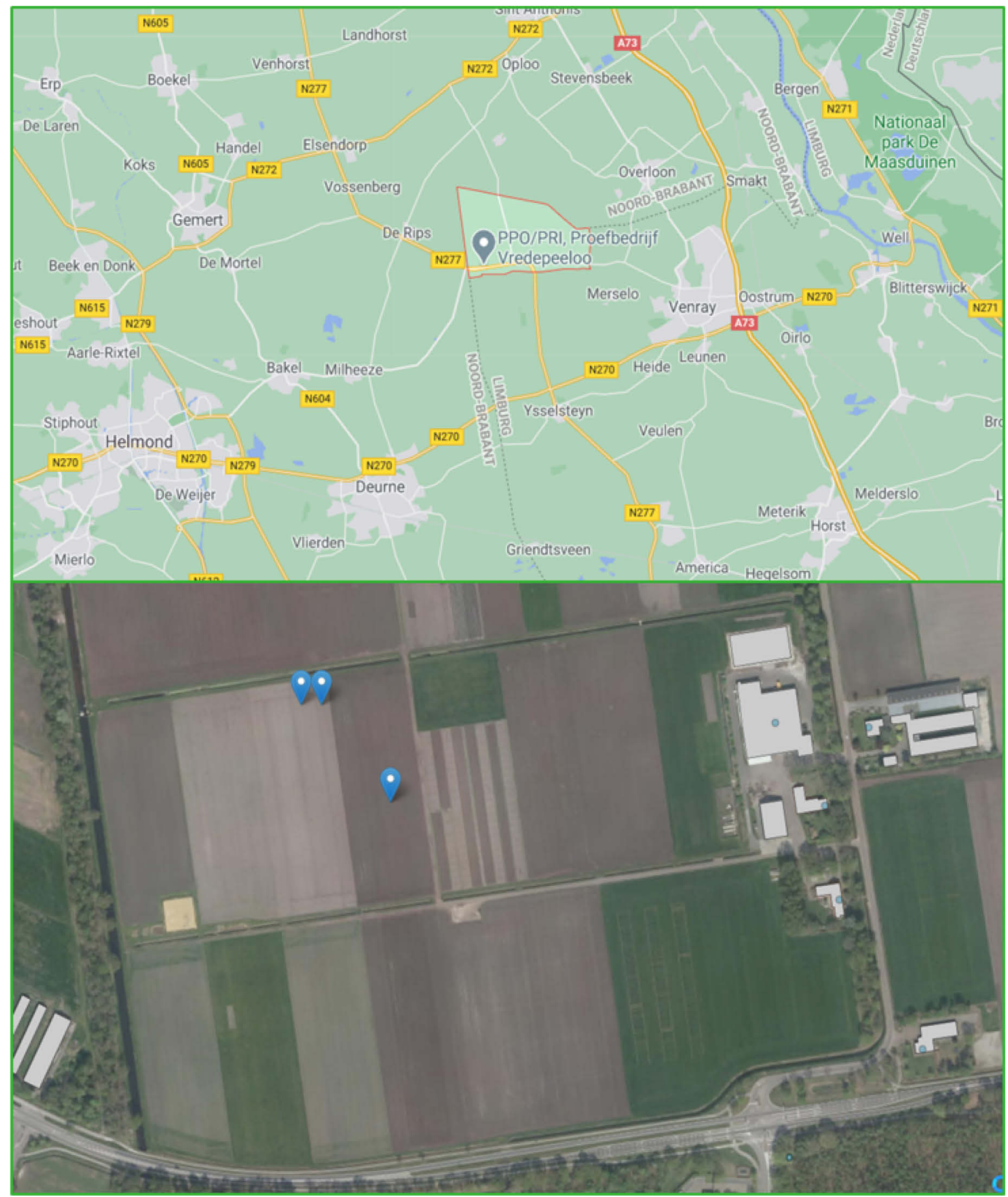

Figuur 2.4 Boven: Vredepeel topografische ligging; Onder: Locatie proefveld Ploeg30 (perceel 27.1b, plot 48, Noordwest), locatie proefveld NKG15 (perceel 27.1a, plot 40, Noordoost), locatie grondwaterstandbuis (Zuidoost). 
In Figuur 2.5 is een nadere indeling gegeven van de ligging van de percelen, de plots en de bijbehorende behandelingen.

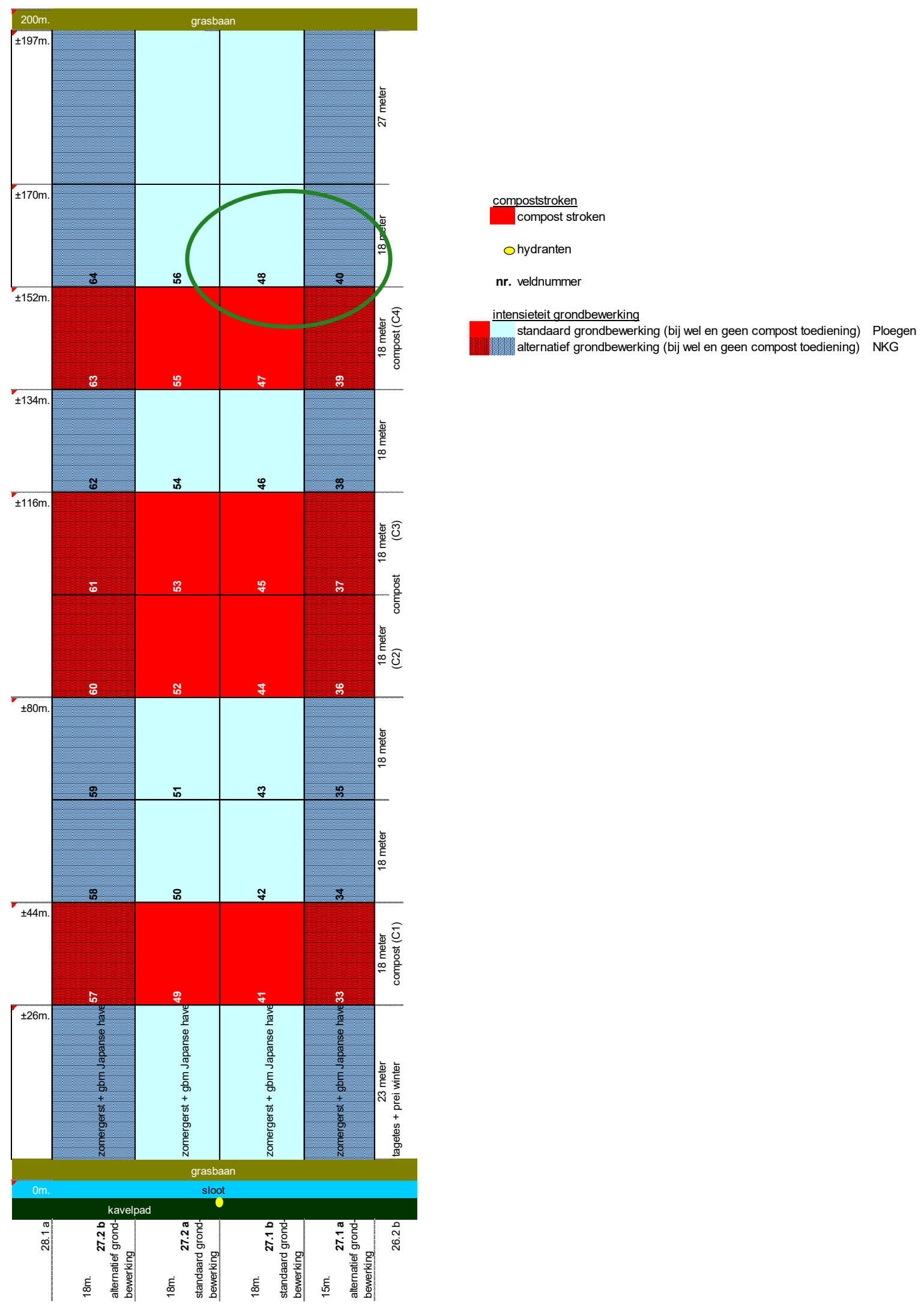

Figuur 2.5 Proefveldnummering en bewerkingen. 


\subsubsection{Bedrijfssysteem}

\section{Gangbaar bedrijfssysteem}

- Vruchtwisseling: Consumptieaardappel-conservenerwt-prei-zomergerst-peen-mais.

- Bemesting: Twee bemestingsstrategieën, LAAG en STANDAARD. In LAAG wordt geen organische stof aangevoerd met mest, alleen kunstmest en bewerkte meststromen. In STANDAARD wordt bemest met (rundvee)drijfmest, aangevuld met kunstmest. Daarnaast deelproef met toepassen van compost.

- Zaai-, plant- en pootbedbereiding zijn zo veel mogelijk gelijk gehouden tussen de systemen. In een enkel geval is hiervan afgeweken.

- Onkruidbestrijding: Er wordt deels gebruikgemaakt van vorstgevoelige groenbemesters om het gebruik van glyfosaat te voorkomen; daarnaast worden fors ontwikkelde groenbemesters in de winter geklepeld. In de afgelopen jaren is er geen glyfosaat toegepast.

\section{Biologisch bedrijfssysteem}

- Vruchtwisseling: Consumptieaardappel-conservenerwt-prei-zomergerst-peen-mais.

- Bemesting: Vaste mest en drijfmest, in enkele teelt aangevuld met vinassekali.

- Zaai-, plant- en pootbedbereiding zijn zo veel mogelijk gelijk gehouden tussen de systemen. In een enkel geval is hiervan afgeweken.

- Onkruidbestrijding: Op NKG-percelen is meer handwerk nodig om de percelen schoon te houden dan op de geploegde percelen.

\subsubsection{Behandelingen}

De proef is opgezet om de effecten van de grondmanagementsystemen ploegen en NKG met elkaar te vergelijken. Op perceel 27.1 zijn de daarvoor de volgende bewerkingen onderscheiden:

\section{- Ploegen (Ploeg30):}

Bij deze kerende grondbewerking wordt er met ondergronders geploegd tot $30 \mathrm{~cm}$. Dit is de hoofdgrondbewerking en wordt elk voorjaar uitgevoerd op plot 48 van perceel 27.1b: het westelijke perceel, (code 221 voor metingen tensiometers).

\section{- Niet-kerende grondbewerking met cultivator (NKG15):}

Bij deze niet-kerende grondbewerking wordt er gecultiveerd met 9 tanden (= 1 werkgang) tot een diepte van ongeveer $15 \mathrm{~cm}$. Dit is de hoofdgrondbewerking en wordt elk voorjaar uitgevoerd op plot 40 van perceel 27.1a: het oostelijke perceel, (code 222 voor metingen tensiometers).

- Ondiep ploegen: Niet uitgevoerd in dit onderzoek in Vredepeel.

- Niet-kerende grondbewerking zonder cultiveren (NKG0): Niet uitgevoerd in Vredepeel.

In Tabel 2.2 en Tabel 2.3 zijn de locaties en behandelingen samengevat.

Tabel 2.3 Plotgegevens in Vredepeel.

\begin{tabular}{llllll} 
Perceel & Plot & RDx & RDy & Bewerking & Tensiometercode \\
\hline $27.1 \mathrm{~b}$ & 48 & 186904.531 & 394852.047 & Ploeg30 & 221 \\
\hline $27.1 \mathrm{a}$ & 40 & 186921.740 & 394852.106 & NKG15 & 222 \\
\hline
\end{tabular}

\subsubsection{Veldmetingen}

Op 4 mei 2020 zijn er profielbeschrijvingen gemaakt van de twee plots, zijn er bodemmonsters genomen uit drie bodemhorizonten per plot voor analyse in het bodemhydrofysisch laboratorium en zijn in het veld tensiometers geplaatst in die verschillende bodemhorizonten om de vochtcondities gedurende een groeiseizoen te kunnen monitoren. Deze gegevens zijn gebruikt ter validatie van het 1D-SWAP-model. De metingen zijn alleen in 2020 uitgevoerd. 


\subsection{Bodemanalyse hydrofysisch laboratorium}

De monsters uit Lelystad en Vredepeel zijn voor de verschillende bodemhorizonten onderzocht op de volgende eigenschappen:

- Korrelgrootteverdeling

- Gloeiverlies, als maat voor het organischestofgehalte

- Waterretentiekarakteristiek (vochthoeveelheid als functie bodemwaterpotentiaal)

- Waterdoorlatendheidskarakteristiek (doorlatendheid als functie van het vochtgehalte en bodemwaterpotentiaal)

- Verzadigde waterdoorlatendheid

- Afleiding van de Mualem-van Genuchten-parameters

Een uitgebreide beschrijving van de analysemethoden (Bakker et al., 2020) is weergegeven in Bijlage 1.

\subsection{Beoordelingswijze hydrofysische bodemanalyses}

In deze paragraaf wordt een aantal drempelwaarden voor bodemfysische eigenschappen vergeleken met de gemeten waarden. Deze eigenschappen zijn essentieel voor de bewortelbaarheid en de infiltratiecapaciteit van water. We geven eerst een kort overzicht van deze drempelwaarden. In Van den Akker \& De Groot (2008) is een uitgebreidere beschrijving gegeven.

\section{Poriënvolume}

De meeste plantenwortels hebben moeite met de beworteling van bodems met een poriënvolume kleiner dan 40\% (Hidding, 1961).

$\mathrm{n}>40 \%$

Niet alleen is de indringweerstand van een grond met dit lage poriëngehalte vaak te hoog, maar ook zijn er problemen met de zuurstofvoorziening naar de wortels (Bakker et al., 1987; Tacket and Pearson, 1964). Poriënvolumes van $40 \%$ zijn in Nederland gekoppeld aan zandgronden en lichte zavels (kleigehalten < 17,5\%). In Nederland hebben kleigronden bijna altijd een poriëngehalte groter dan $40 \%$.

\section{Droog volumegewicht $(D b)$}

Voor zandgronden met een laag organischestofgehalte (zoals in het algemeen het geval is bij een zandondergrond) kan de drempelwaarde van $40 \%$ van het poriëngehalte worden omgezet in een drempelwaarde voor het volumegewicht:

$\mathrm{Db}<1.6 \mathrm{~g} \mathrm{~cm}^{-3}$

Voor grond met meer dan 17,5\% lutum kan de volgende vergelijking worden gebruikt voor de drempelwaarde voor de dichtheid:

$\mathrm{Db}<1.75-0.009 \mathrm{~g} \mathrm{~cm}^{-3}$

Waarin $\mathrm{C}=$ percentage lutum (klei)

Verzadigde waterdoorlatendheid (Ksat)

Volgens Lebert et al. (2003) is voor een ondergrond een verzadigde waterdoorlatendheid van Ksat = $10 \mathrm{~cm} . \mathrm{d}^{-1}$ een goede drempelwaarde. Deze drempelwaarde van $10 \mathrm{~cm} . \mathrm{d}^{-1}$ voor de verzadigde waterdoorlatendheid komt in Nederland overeen met de classificatie "slecht" (Cultuurtechnische Vereniging, 1988).

Ksat $>10 \mathrm{~cm} \mathrm{dag}^{-1}$ 
Luchtgevulde poriëngehalte $\left(n_{g}\right)$

Bakker et al., (1987) hebben voor een serie Nederlandse landbouwgronden structuurafhankelijke relaties vastgesteld tussen het luchtgevulde poriëngehalte $n_{g}$ en de diffusie coëfficiënt Ds. Volgens Bakker et al. (1987) hebben plantenwortels nooit aeratieproblemen bij Ds $>3010^{-8} \mathrm{~m}^{2} \mathrm{~s}^{-1}$ en hebben ernstige aeratieproblemen bij Ds $<1.510^{-8} \mathrm{~m}^{2} \mathrm{~s}^{-1}$. De relaties van Bakker et al. (1987) zijn gebruikt om deze limieten om te zetten naar drempelwaarden voor $n_{g}$ in Tabel 2.4.

Tabel 2.4 Het vastgestelde minimum en voorkeur van het luchtgevulde poriëngehalte $n_{g}$ om (ernstige) anaerobe condities voor plantenwortels te voorkomen.

\begin{tabular}{lll}
\multirow{2}{*}{ Bodemstructuur } & Het luchtgevulde poriëngehalte ng moet zijn: \\
\cline { 2 - 3 } Zeer goed & $>2 \%$ & Bij voorkeur \\
\hline Goed & $>5 \%$ & $>14 \%$ \\
\hline Matig & $>8 \%$ & $>15 \%$ \\
\hline Niet, Slecht & $>12 \%$ & $>21 \%$ \\
\hline
\end{tabular}

In het algemeen is de kwaliteit van de structuur van de ondergrond slechts matig en van zandgronden en lichte zavels matig en slecht. Voor deze gronden nemen we daarom als drempelwaarde dat het luchtgevulde poriëngehalte minimaal $10 \%$ moet zijn. Bij een drempelwaarde voor het luchtgevulde poriëngehalte hoort een vochttoestand, die het best kan worden uitgedrukt in een vochtspanning. Een goede maat is dan de veldcapaciteit, die voor de meeste gronden gedefinieerd wordt als het vochtgehalte bij een vochtspanning van $-50 \mathrm{~cm}$ waterdruk (Ten Cate et al., 1995). Voor goed doorlatende en niet-opdrachtige hangwaterprofielen zou $-100 \mathrm{~cm}$ waterdruk kunnen worden aangehouden (Ten Cate et al., 1995). Voor een verdichte ondergrond wordt voor de drempelwaarde van minimaal $10 \%$ luchtgevulde poriën uitgegaan van een vochtspanning van $-50 \mathrm{~cm}$ waterdruk.

Penetrometer- indringweerstand (Iw)

De indringweerstand wordt in Nederland gemeten met een penetrometer waarbij een conus met een basisoppervlak van $1 \mathrm{~cm}^{2}$ en een tophoek van $60^{\circ}$ wordt gebruikt. Door de kracht waarmee de conus in de grond wordt geduwd te delen door het oppervlak van de basis van de conus wordt de indringweerstand Iw uitgedrukt in MegaPascal (MPa) verkregen. Omdat de indringweerstand sterk afhankelijk is van de vochttoestand van de grond moeten indringweerstanden worden gemeten als de grond vochtig is, bijvoorbeeld als de grond min of meer op veldcapaciteit is. De kritische grens voor beworteling ligt bij een indringweerstand van 2,5 à 3,0 MPa (ten Cate et al., 1995). Als er een stelsel van voldoende grote poriën aanwezig is, verschuift de kritische grens naar 3-5 MPa voor zandgronden (Ten Cate et al., 1995). Als een soort gemiddelde wordt in dit rapport een drempelwaarde van de indringweerstand genomen ter grootte van:

$\mathrm{IW}=3 \mathrm{MPa}$

\subsection{SWAP-modellering}

Voor de beide locaties zijn SWAP-berekeningen uitgevoerd. SWAP is een model voor de beschrijving van het vochttransport in de onverzadigde zone van de bodem. Aan het SWAP-model is het gewasgroeimodel WOFOST gekoppeld. Met deze modelcombinatie zijn de samenhang van de verschillende locatiegegevens, zoals bodemopbouw en watermanagement, en de effecten van verschillende beheermaatregelen op de gewasgroei onderzocht. Het model laat zien of de gevonden gewasreducties te verklaren zijn uit de invoergegevens of dat ze voortkomen uit onvoorziene toevalligheden. In verschillende scenario's is bepaald hoe beheermaatregelen kunnen doorwerken in grondwaterstanden, bodemvocht en opbrengsten. 
Per scenario zijn de effecten bepaald op:
a. De grondwaterstanden
b. Het vochtgehalte in de bodem
c. De landbouwkundige opbrengsten

In dit onderzoek gaat het om de effecten van systeemexperimenten op een zavelgrond in Lelystad en op een zandgrond in Vredepeel. Hierbij zijn de modeluitkomsten vergeleken met gemeten data.

Voor de modellering is gebruikgemaakt van SWAP-versie 4.1.59.

In de volgende paragrafen is beschreven welke basisgegevens zijn gebruikt en hoe de modelopzet heeft plaatsgevonden. 


\section{Basisgegevens en Resultaten}

\subsection{Lelystad basisgegevens en veldmetingen}

\subsubsection{Bodemopbouw en hydrofysische bodemparameters}

In Tabel 3.1 zijn gegevens van de verschillende plots opgenomen die tijdens de veldschouw in april 2019 zijn aangetroffen.

Tabel 3.1 Kenmerken plots op basis van de veldschouw (april 2019).

\begin{tabular}{|c|c|c|c|c|c|c|c|c|c|}
\hline Locatie & Bewerking & $\mathrm{x}$ & $\mathbf{Y}$ & Bodemcode & $\begin{array}{l}\text { GHG } \\
\mathrm{cm}-\mathrm{mv}\end{array}$ & $\begin{array}{l}\text { GLG } \\
\mathrm{cm}-\mathrm{mv}\end{array}$ & $\begin{array}{l}\text { Bewortelings- } \\
\text { diepte cm }\end{array}$ & GT & $\begin{array}{l}\text { HOOGTE } \\
\text { m+NAP }\end{array}$ \\
\hline $\mathrm{P} 1, \mathrm{~B} 1$ & Ploeg15 & 167702.7 & 506204.0 & AKM5p235a & 100 & 140 & 70 & VIIo & -4.37 \\
\hline P14, B66 & NKGO & 167695.4 & 506408.6 & AKM5p235a & 100 & 150 & 80 & VIIo & -4.44 \\
\hline P16, B76 & Ploeg25 & 167696.6 & 506438.8 & AKM5p235a & 110 & 150 & 80 & VIIo & -4.44 \\
\hline
\end{tabular}

Tabel 3.2 toont dat op alle onderzochte bedden tot 30 à $35 \mathrm{~cm}$ diepte een zware zavelgrond is aangetroffen. Daaronder bestaat de grond tot op boordiepte (circa 1,5 m -mv) uit een lichte zavel tot sterk lemig fijn zand. De kolommen zijn alle gebaseerd op veldschattingen, met uitzondering van het bouwsteennummer (een-na-laatste kolom). De hier aangegeven bouwsteennummers, zoals bedoeld in de Staringreeks (Heinen et al., 2020), zijn gebaseerd op metingen in het bodemhydrofysisch laboratorium aan monsters uit Lelystad.

Tabel 3.2 Bodemopbouw en vertaling naar bouwstenen.

\begin{tabular}{|c|c|c|c|c|c|c|c|c|c|c|c|c|c|c|c|c|c|c|}
\hline 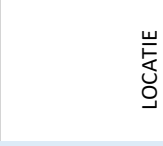 & 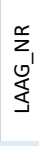 & 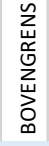 & 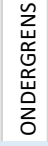 & 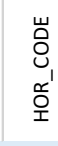 & 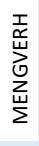 & $\begin{array}{l}\text { u } \\
0 \\
\vdots \\
0 \\
0 \\
o ̛ ⿱ \\
0\end{array}$ & $\begin{array}{l}\sum \\
\vdots \\
5\end{array}$ & $\sum_{\text {出 }}$ & 올 & 亲 & 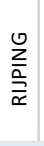 & 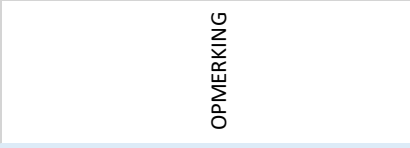 & $\stackrel{5}{\bar{二}}$ & 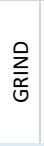 & 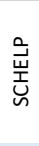 & & 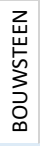 & \\
\hline \multirow[t]{4}{*}{ Blok 1, Bed 1} & 1 & 0 & 30 & $1 \mathrm{Ap}$ & 0 & 3.0 & 24 & 0 & 0 & 3 & 5 & & 40 & 0 & & B09 & & zware zavel \\
\hline & 2 & 30 & 35 & $1 \mathrm{Cg}$ & 0 & 0.5 & 18 & 0 & 0 & 3 & 5 & & 35 & 0 & & 009 & & matig lichte zavel \\
\hline & 3 & 35 & 110 & $2 \mathrm{Cg}$ & 0 & 0.7 & 9 & 0 & 0 & 3 & & gelaagd wat roest & 20 & 0 & & 008 & & zeer lichte zavel \\
\hline & 4 & 110 & 160 & $2 \mathrm{Cer}$ & 0 & 5.0 & 9 & 0 & 0 & 3 & 5 & humeuze banden & 20 & 0 & & 008 & & zeer lichte zavel \\
\hline \multirow[t]{5}{*}{ Blok3, Bed 12} & 1 & 0 & 35 & $1 A p$ & 0 & 3.0 & 24 & 0 & 0 & 3 & 5 & & 30 & 0 & & B09 & & zware zavel \\
\hline & 2 & 35 & 45 & $2 \mathrm{Cg} 1$ & 0 & 1.0 & 9 & 0 & 0 & 3 & 5 & schelpenbank & 20 & 0 & 30 & 008 & & zeer lichte zavel \\
\hline & 3 & 45 & 110 & $2 \mathrm{Cg} 2$ & 0 & 1.0 & 9 & 0 & 0 & 3 & 5 & zeer gelaagd & 20 & 0 & 0 & 008 & & zeer lichte zavel \\
\hline & 4 & 110 & 140 & $2 \mathrm{Cg} 3$ & 0 & 2.0 & 9 & 0 & 0 & 3 & 5 & donkere banden, roest & 20 & 0 & 0 & 008 & & zeer lichte zavel \\
\hline & 5 & 140 & 150 & 2 Cer & 0 & 3.0 & 9 & 0 & 0 & 3 & 5 & & 20 & 0 & 0 & 008 & & zeer lichte zavel \\
\hline \multirow[t]{3}{*}{ Blok 14, Bed 66} & 1 & 0 & 35 & $1 \mathrm{Ap}$ & 0 & 3.0 & 20 & 0 & 0 & 3 & & soms stroresten & 40 & 0 & & B09 & & zware zavel \\
\hline & 2 & 35 & 110 & $1 \mathrm{Cg}$ & 0 & 0.7 & 9 & 0 & 0 & 3 & & gelaagd & 20 & 0 & 0 & 008 & & zeer lichte zavel \\
\hline & 3 & 110 & 150 & 1Cer & 0 & 5.0 & 9 & 0 & 0 & 3 & 5 & gelaagd met humeuze banden, donkergrijs & 20 & 0 & 0 & 008 & & zeer lichte zavel \\
\hline \multirow[t]{4}{*}{ Blok 16, Bed 76} & 1 & 0 & 30 & $1 \mathrm{Ap}$ & 0 & 3.0 & 20 & 0 & 0 & 3 & 5 & & 40 & 0 & 2 & B09 & & zware zavel \\
\hline & 2 & 30 & 50 & 1Cg1 & 0 & 0.5 & 16 & 0 & 0 & 3 & 5 & gelaagd, wat lutumrijkere banden & 30 & 0 & 0 & 009 & & matig lichte zavel \\
\hline & 3 & 50 & 90 & 1Cg2 & 0 & 0.5 & 7 & 20 & 110 & 3 & 5 & gelaagd & 20 & 0 & 0 & 003 & & sterk lemig, fijn zand \\
\hline & 4 & 90 & 150 & 1Cer & 0 & 5.0 & 9 & 0 & 0 & 3 & 5 & donkergrijs met zwarte humeuze banden & 25 & 0 & 0 & 008 & & zeer lichte zavel \\
\hline
\end{tabular}

De bodemmonsters voor het bepalen van de hydrofysische bodemeigenschappen zijn op 23 en 24 april 2019 genomen en geven daarmee de status van de bodem op die datum weer. In Tabel 3.3 en Tabel 3.6 zijn de gemeten verzadigde waterdoorlatendheden weergegeven. 
Tabel 3.3 Gemeten verzadigde waterdoorlatendheid op twee bedden en verschillende diepten.

\begin{tabular}{|c|c|c|c|c|}
\hline \multirow[t]{2}{*}{ Locatie } & \multirow[t]{2}{*}{ Bewerking } & \multicolumn{2}{|c|}{ Monsterdiepte (cm -mv) } & \multirow{2}{*}{$\begin{array}{l}\text { Ks gemiddeld } \\
{[\mathrm{cm} / \mathrm{d}]}\end{array}$} \\
\hline & & van & tot & \\
\hline \multirow[t]{2}{*}{$\mathrm{BL} 3, \mathrm{BE} 12$} & \multirow[t]{2}{*}{ NKG20 } & 10 & 20 & 3062.2 \\
\hline & & 55 & 65 & 26.0 \\
\hline \multirow[t]{2}{*}{ BL16, BE76 } & \multirow[t]{2}{*}{ Ploeg25 } & 10 & 20 & 282.9 \\
\hline & & 60 & 70 & 51.3 \\
\hline
\end{tabular}

Een lichte zavelgrond zwelt en krimpt nauwelijks bij respectievelijk bevochtiging en uitdroging. Daardoor heeft een dergelijke grond een gering fysisch herstelvermogen ten aanzien van bodemverdichting en is voor het herstel ervan vooral afhankelijk van bodemflora en bodemfauna. Bij NKG is het biologische herstelvermogen in potentie groter dan bij ploegen, omdat bij die beheersmaatregel het bodemleven betere kansen krijgt om zich te ontwikkelen gedurende de jaren. Bij NKG zijn tot $35 \mathrm{~cm}-\mathrm{mv}$ hogere verzadigde waterdoorlatendheden gemeten dan bij ploegen. ${ }^{3}$

In Tabel 3.4 zijn de gemiddelde gemeten droge bulkdichtheden weergegeven. Hieruit blijkt dat rond 25 à $30 \mathrm{~cm}$-mv de hoogste dichtheden zijn gemeten (donkergroen). De laagste dichtheden zijn op die diepte gemeten op de blokken 3 (NKG20) en 16 (Ploeg25).

Tabel 3.4 Gemeten droge bulkdichtheden op verschillende diepten (g/cm3), bepaald in april 2019.

\begin{tabular}{|c|c|c|c|c|c|}
\hline \multicolumn{2}{|c|}{ Diepte-mv (cm) } & \multirow{2}{*}{$\begin{array}{l}\text { BL1 } \\
\text { Ploeg15 }\end{array}$} & \multirow{2}{*}{$\begin{array}{l}\text { BL3 } \\
\text { NKG20 }\end{array}$} & \multirow{2}{*}{$\begin{array}{l}\text { BL14 } \\
\text { NKG0 }\end{array}$} & \multirow{2}{*}{$\begin{array}{l}\text { BL16 } \\
\text { Ploeg25 }\end{array}$} \\
\hline Boven & Onder & & & & \\
\hline 0 & 5 & & & & \\
\hline 10 & 15 & 1.33 & 1.33 & 1.27 & 1.32 \\
\hline 15 & 20 & & 1.33 & & 1.32 \\
\hline 25 & 30 & 1.69 & 1.57 & 1.62 & 1.53 \\
\hline 30 & 35 & 1.69 & 1.57 & & 1.53 \\
\hline 35 & 40 & & & & \\
\hline 40 & 45 & & & & \\
\hline 60 & 65 & 1.33 & 1.27 & & 1.31 \\
\hline 65 & 70 & & & & 1.31 \\
\hline 70 & 75 & & & & \\
\hline 75 & 80 & & & & \\
\hline
\end{tabular}

Omdat niet op alle bedden op elke diepte bodemmonsters genomen en geanalyseerd konden worden, zijn de locaties en diepten waarop wel monsters zijn genomen strategisch gekozen. Sommige monsterresultaten zijn daarom aan verschillende lagen toegekend. In Tabel 3.5 is deze toekenning weergegeven. Op alle lagen is dus uitgegaan van lokaal gemeten waarden, met uitzondering van Blok 16, Bed 76, Laag 3. Omdat dit een afwijkende, niet-lokaal gemeten grondsoort is, is gebruikgemaakt van een Staringreeks bouwsteen. De aangegeven monsterresultaten en Staringreeksbouwsteen zijn gebruikt bij de SWAP-simulaties.

3 Een zware zavel kan wel genoeg krimpen om verdichting te kunnen opheffen. Matig lichte zavel heeft meestal niet voldoende krimp en zwel. Meer organische stof vergroot het zwel- en krimpvermogen van een grond en daarmee het herstelvermogen. De hoeveelheid moet wel meer zijn dan in veel ondergronden aanwezig is $(0,3-1 \%)$ : bij $4 \%$ in de ondergrond ontstaat er al veel herstelvermogen en bewortelbaarheid. 
Tabel 3.5 Toekenning van de gemeten bodemfysische karakteristieken aan de verschillende lagen. De hydrofysische metingen van de monsters uit de laatste twee kolommen hebben een bouwsteennaam gekregen, zoals weergegeven in kolom 6 (afgeleid van de korrelgrootteverdeling, organische stof en dichtheid). Deze bouwsteennamen zijn ook weergegeven in Figuur 3.1. De letter ' $P$ ' in de laatste kolom staat voor het betreffende bloknummer waaruit het monster is genomen. Omdat niet van alle lagen hydrofysische kenmerken in het laboratorium zijn bepaald, zijn kenmerken van andere plekken toegekend aan de betreffende laag.

\begin{tabular}{|c|c|c|c|c|c|c|c|}
\hline \multirow[t]{2}{*}{ Locatie } & \multirow[t]{2}{*}{ Laag } & \multirow[t]{2}{*}{ Boven } & \multirow[t]{2}{*}{ Onder } & \multirow[t]{2}{*}{ Beschrijving } & \multirow[t]{2}{*}{ Bouwsteen } & \multirow{2}{*}{$\begin{array}{l}\text { BodFys } \\
\text { laagmonster }\end{array}$} & \multirow{2}{*}{$\begin{array}{l}\text { Toekenning } \\
\text { BodFys }\end{array}$} \\
\hline & & & & & & & \\
\hline \multirow{3}{*}{$\begin{array}{l}\text { Blok 1, Bed } 1 \\
\text { Ploeg15 }\end{array}$} & 1 & 0 & 25 & Zware zavel & B09 & & P3B12.1 10-20 \\
\hline & 3 & 35 & 110 & Zeer lichte zavel & 008 & & P3B12.3 55-65 \\
\hline & 4 & 110 & 160 & Zeer lichte zavel & 008 & & P3B12.3 55-65 \\
\hline \multirow{4}{*}{$\begin{array}{l}\text { Blok3, Bed } 12 \\
\text { NKG20 }\end{array}$} & 1 & 0 & 25 & Zware zavel & B09 & P3B12.1 10-20 & \\
\hline & 2 & 25 & 35 & Zware zavel & 010 & P3B12.2 25-35 & \\
\hline & 3 & 35 & 45 & Zeer lichte zavel & 008 & & P3B12.3 55-65 \\
\hline & 4 & 45 & 110 & Zeer lichte zavel & 008 & P3B12.3 55-65 & \\
\hline \multirow{5}{*}{$\begin{array}{l}\text { Blok 14, Bed } 66 \\
\text { NKG0 }\end{array}$} & 1 & 0 & 20 & Zware zavel & B09 & & P3B12. 1 10-20 \\
\hline & 2 & 20 & 35 & Zware zavel & 010 & & P3B12.2 25-35 \\
\hline & 3 & 35 & 110 & Zeer lichte zavel & 008 & P14B66 50-60 & \\
\hline & 4 & 110 & 150 & Zeer lichte zavel & 008 & & P14B66 50-60 \\
\hline & 5 & 150 & 600 & Zeer lichte zavel & 008 & & P14B66 50-60 \\
\hline \multirow{4}{*}{$\begin{array}{l}\text { Blok 16, Bed } 76 \\
\text { Ploeg25 }\end{array}$} & 1 & 0 & 20 & Zware zavel & B09 & P16B76.1 10-20 & \\
\hline & 2 & 20 & 30 & Zware zavel & 010 & P16B76.2 25-35 & \\
\hline & 3 & 30 & 50 & Matig lichte zavel & 009 & & Staring 2018009 \\
\hline & 4 & 50 & 90 & Sterk lemig, fijn zand & 003 & P16B76.4 60-70 & \\
\hline
\end{tabular}

Tabel 3.6 geeft de uit de laboratoriummetingen afgeleide Mualem-Van Genuchten (MvG-)parameters. De gemeten verzadigde waterdoorlatendheid $\mathrm{Ksm}$ kan sterk variëren voor de verschillende monsters en over de verschillende percelen, vooral door het al dan niet voorkomen van macroporiën ten gevolge van bijvoorbeeld wormen, krimpscheuren of aggregaat vorming. De modelparameter Ksf volgt de dwingende vorm van het MvG-model en kan vooral voor de verzadigde waterdoorlatendheid behoorlijk afwijken van de gemeten doorlatendheid $\mathrm{Ksm}$. De Mualem-Van Genuchten-curves van de waterretentie- en waterdoorlatendheidskarakteristieken zijn weergegeven in Figuur 3.1.

Tabel 3.6 Mualum-van Genuchten parameters, afgeleid van de hydrofysische metingen aan de bodemmonsters.

\begin{tabular}{|c|c|c|c|c|c|c|c|c|c|c|}
\hline Monster & Bewer- & Bovenkant & Onderkant & Or & Os & a & $n$ & L & Ksf & Ksm \\
\hline & & $\mathrm{cm}-\mathrm{mv}$ & $\mathrm{cm}-\mathrm{mv}$ & $\mathrm{cm} 3 . \mathrm{cm}-3$ & $\mathrm{~cm} 3 . \mathrm{cm}-3$ & $\mathrm{~cm}-1$ & - & - & $\mathrm{cm} \cdot \mathrm{d}-1$ & cm.d-1 \\
\hline P3B12.1 & \multirow[t]{2}{*}{ NKG20 } & 10 & 20 & 0 & 0.432 & 0.0384 & 1.1700 & -5.0460 & 10.52 & 3062.2 \\
\hline P3B12.2 & & 25 & 35 & - & - & - & - & - & - & - \\
\hline P14B66 & NKGO & 50 & 60 & 0 & 0.450 & 0.0059 & 1.5566 & 5.5295 & 0.51 & - \\
\hline P16B76.1 & \multirow[t]{3}{*}{ Ploeg25 } & 10 & 20 & 0 & 0.408 & 0.0314 & 1.1796 & -3.3144 & 32.74 & 282.9 \\
\hline P16B76.2 & & 25 & 35 & 0 & 0.382 & 0.0048 & 1.2533 & 2.6164 & 0.71 & 83 \\
\hline P16B76.4 & & 60 & 70 & 0 & 0.478 & 0.008 & 1.2558 & 7.5351 & 7.79 & - \\
\hline
\end{tabular}




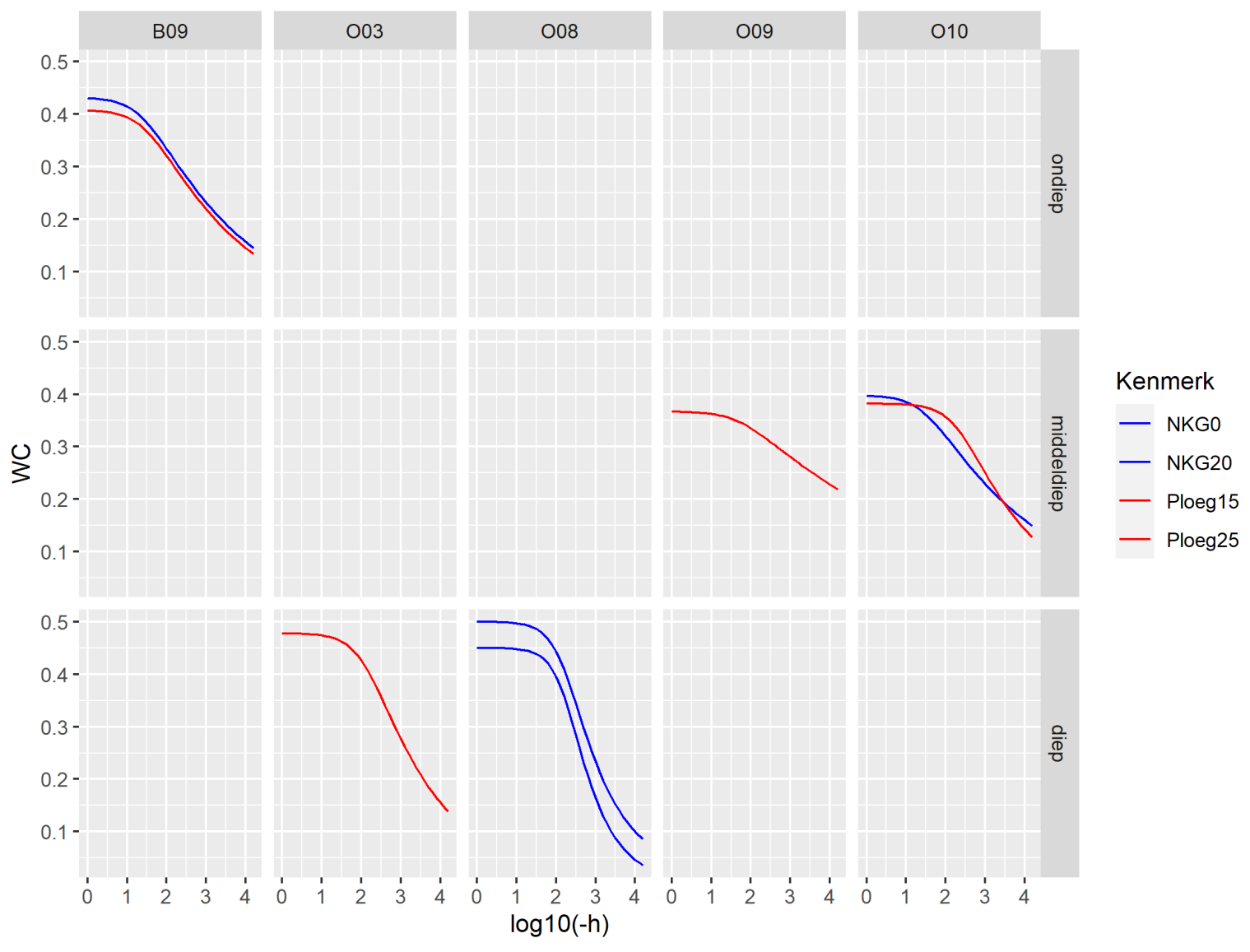

Figuur 3.1 Overzicht van de Mualem-Van Genuchten-retentiekarakteristieken van de verschillende lagen zoals bedoeld in Tabel 3.5. Deze retentiekarakteristieken zijn afgeleid van hydrofysische metingen aan monsters die afkomstig zijn van de proeflocatie in Lelystad.

In Tabel 3.7 is een overzicht gegeven van de hydrofysische kenmerken. De kenmerken die voor directe beoordeling in aanmerking komen, zijn opgenomen in het hoofdstuk Discussie (paragraaf 4.1).

Tabel 3.7 Overzicht hydrofysische bodemeigenschappen. In rood de waarden die niet aan de limiet voldoen. Cursief staan waarden die afgeleid zijn uit metingen bij andere monsters.

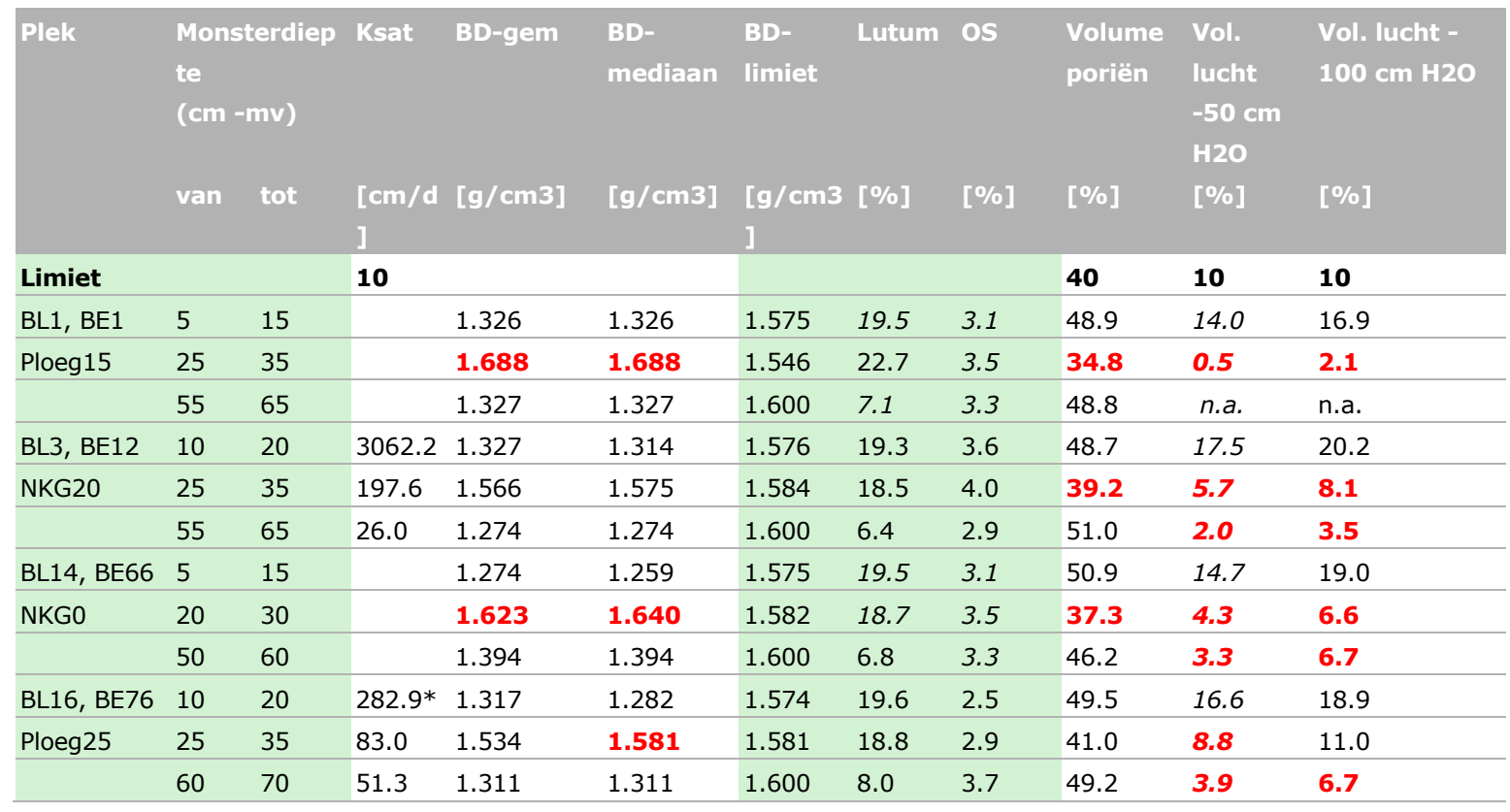

*eerste bepaling is gebruikt, tweede meting had mogelijk lekkage. 


\subsubsection{Grondwaterstandmetingen}

Er zijn geen grondwaterstandmetingen, alleen een inschatting van de GHG en GLG, zoals bepaald bij de profielbeschrijving in het veld (Tabel 3.1).

\subsubsection{Neerslag, verdamping en beregening}

De neerslag en verdamping zijn afkomstig van station Lelystad (KNMI-gegevens). In Bijlage 3 zijn de meteorologische gegevens weergegeven.

Beregening heeft niet plaatsgevonden om de effecten van nalevering van bodemvocht tijdens droogte in beeld te kunnen brengen.

\subsubsection{Oppervlaktewaterstanden, buisdrainage en maaiveldafvoer}

Het proefgebied ligt in een peilvak met een vast oppervlaktewaterpeil (zomer en winter) van NAP $-6,20 \mathrm{~m}$, ofwel circa $175 \mathrm{~cm}$-mv. Daarnaast is er buisdrainage aanwezig die voor de ontwatering van het perceel van veel grotere invloed is dan de hoofdwatergangen. De diepte van de drainage is $110 \mathrm{~cm}$-mv (inschatting op basis van de GHG van circa $100 \mathrm{~cm}-\mathrm{mv}$ ), met een drainafstand van $8 \mathrm{~m}$.

Voor het SWAP-model is een drainageweerstand van $50 \mathrm{~d}$ aangehouden. Dit is een weerstand die hoort bij een goed functionerend drainagesysteem (afvoercapaciteit van $10 \mathrm{~mm} / \mathrm{d}$ bij $50 \mathrm{~cm}$ water boven afvoerniveau drain).

Aangenomen is dat er maaiveldafvoer kan optreden als de grondwaterstanden tot aan maaiveld stijgen. Hiervoor is een afvoerniveau van $5 \mathrm{~cm}-\mathrm{mv}$ gehanteerd met een drainageweerstand van $20 \mathrm{~d}$.

\subsubsection{Geohydrologie}

Boringen in de omgeving geven aan dat de deklaag circa 4 à $5 \mathrm{~m}$ dik is, waarvan de bovenste $2 \mathrm{~m}$ bestaat uit een zavelgrond met daaronder venige afzettingen. Aangezien het een diepe polder betreft, treedt er kwel op die aan de randen van de polder het grootst is. Volgens NHI-gegevens is de kwel gering (maximaal circa $40 \mathrm{~mm} / \mathrm{j}$ ), zoals beschreven in Stuyt (2018).

In Figuur 3.2 is de stijghoogte in het watervoerend pakket gegeven. Hieruit blijkt dat deze behoorlijk stabiel is met een gemiddelde stand van NAP $-5,75 \mathrm{~m}$ en een fluctuatie van plus en min $10 \mathrm{~cm}$. Dit is hoger dan de oppervlaktewaterstanden, hetgeen leidt tot netto kwel. In vergelijking met de diepere lagen zullen de grondwaterstanden in de ondiepe lagen aanzienlijk meer fluctueren onder invloed van neerslag en verdamping en de hoge weerstand van de deklaag in de bovenste $5 \mathrm{~m}$ van het bodemprofiel (Bijlage 4). 


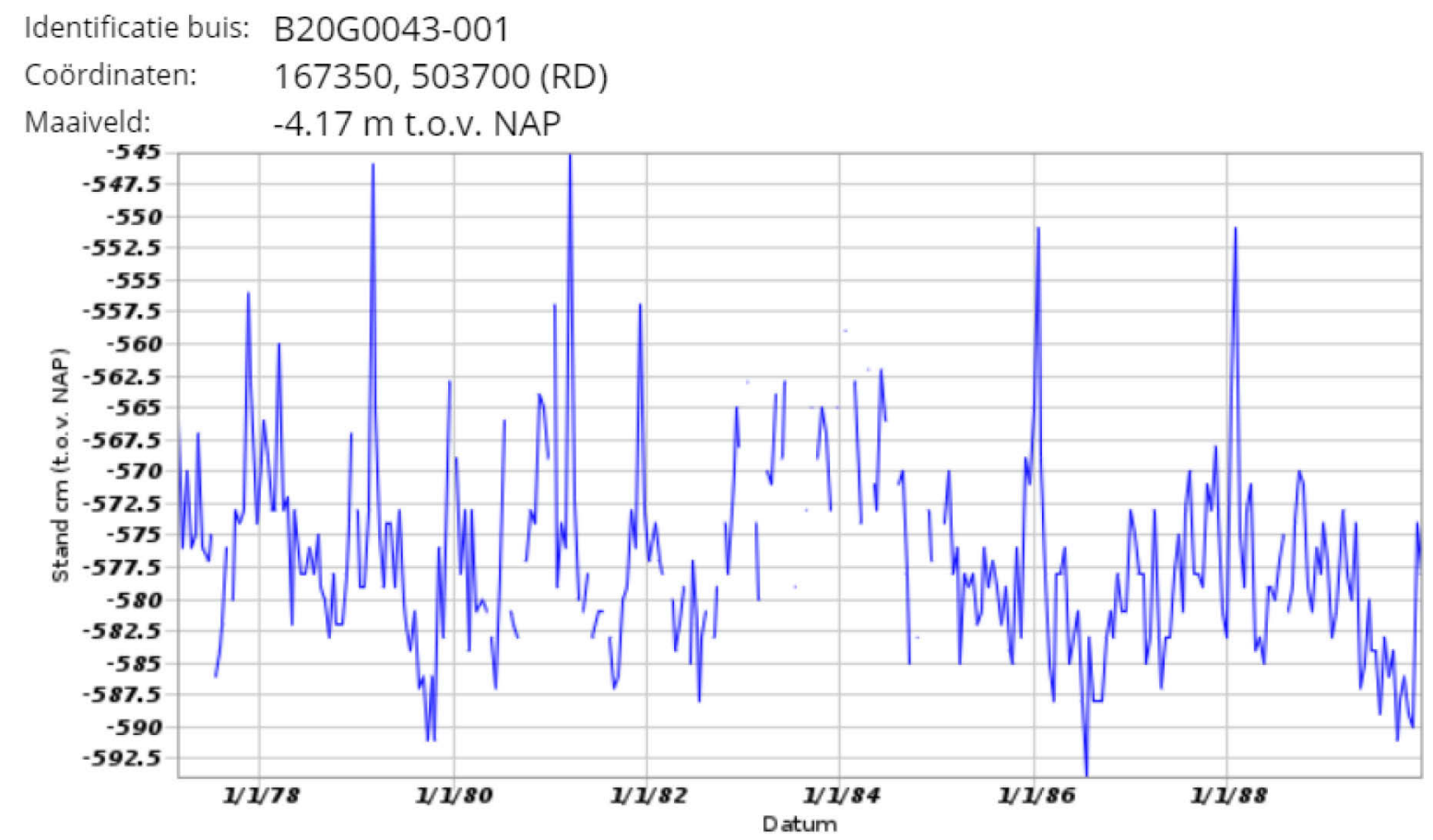

Figuur 3.2 Stijghoogte watervoerend pakket (filter 22-51 m-mv).

\subsubsection{Geteelde gewassen}

In Tabel 3.8 is het teeltplan weergegeven. Tijdens de proef zijn geen groenbemesters geteeld.

Tabel 3.8 Geteelde gewassen.

\begin{tabular}{lll} 
Jaar & Blok 14 en 16 & Blok 1 en 3 \\
\hline 2009 & Suikerbiet & Zomergerst \\
\hline 2010 & Wintertarwe & Zaaiuien \\
\hline 2011 & Zaaiuien & Pootaardappel \\
\hline 2012 & Pootaardappel & Suikerbiet \\
\hline 2013 & Suikerbiet & Zomergerst \\
\hline 2015 & Zomergerst & Zaaiuien \\
\hline 2016 & Zaaiuien & Pootaardappel \\
\hline 2018 & Pootaardappel & Suikerbiet \\
\hline 2019 & Suikerbieten & Zomergerst \\
\hline 2020 & Zomergerst & Zaaiuien \\
\hline
\end{tabular}

*Hiervoor is geen WOFOST-gewasfile beschikbaar: sperzieboon is als vervangend gewas gekozen.

\subsubsection{Veldmetingen drukhoogte}

In het najaar van 2019 zijn na de oogst vochtspanningsmetingen uitgevoerd. De meetresultaten zijn weergegeven in Bijlage 5. Deze resultaten zijn gebruikt bij de validatie van de simulatie met het SWAP-model. 


\subsubsection{Beworteling en indringweerstand}

Ieder gewas heeft een maximale bewortelingsdiepte. Bij een sterk verdichte bodem kunnen de wortels van het gewas niet de potentiële (maximale) diepte bereiken: de indringweerstand Iw is dan te hoog. ${ }^{4}$ Over het algemeen wordt aangenomen dat de beworteling beperkt, maar niet verhinderd is bij $2<$ IW <3MPa. Penetrologger-metingen in de periode 2010-2019 (Figuur 3.3) laten zien dat dit geldt op ca. 40 tot $50 \mathrm{~cm}-\mathrm{mv}$ bij de NKG-grondbewerking. Ploeg25 en NKG20 hebben een iets lagere en dus gunstigere indringweerstand. $\mathrm{Bij} I w>3 \mathrm{MPa}$ wordt wortelgroei in belangrijke mate gehinderd; dit is op circa $80 \mathrm{~cm}$-mv op alle behandelingsplots. De meting in 2019 laat grote verschillen zien tussen ploegen en NKG: op het geploegde veld is de indringweerstand lager. De indringweerstand van de geploegde plot is over de jaren minder variabel dan die van het NKG-veld. Op beide blokken is geen afname in de tijd te zien. Opgemerkt moet worden dat de indringweerstand sterk afhankelijk is van de vochtsituatie, waardoor ook de variatie tussen de metingen behoorlijk groot zal zijn. Dit kan een deel van de gevonden verschillen verklaren.

Bijlage 6 geeft de mediane indringweerstand op de blokken 14 (NKG0) en 16 (Ploeg25).

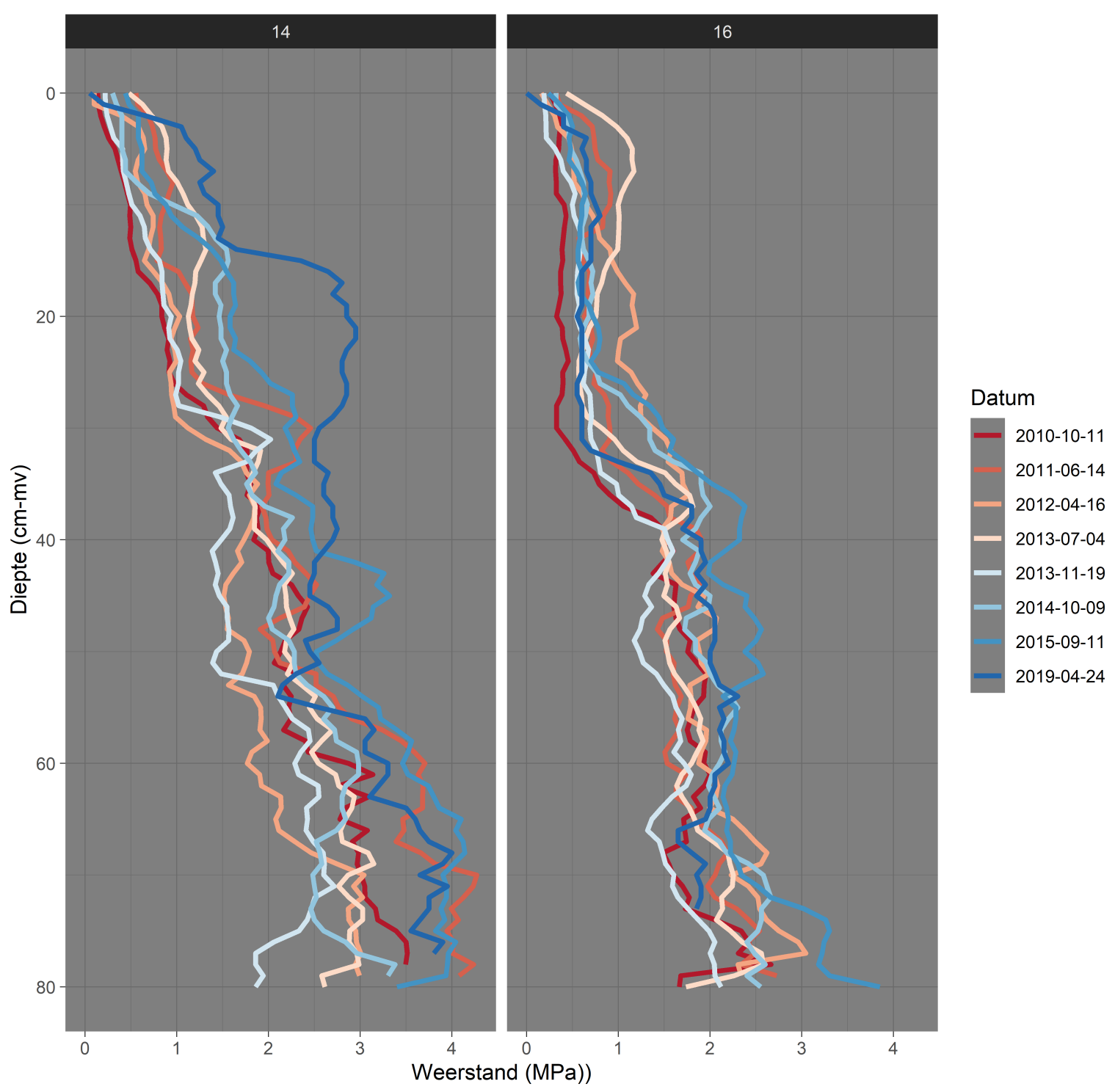

Figuur 3.3 Indringweerstand Iw op Blok 14 NKGO en Blok 16 Ploeg25 over de periode 2010-2019.

\footnotetext{
${ }^{4}$ Beworteling wordt niet alleen beperkt door te hoge indringweerstanden, maar ook door de aeratiemogelijkheden. Dus niet alleen een hoge Iw belemmert de bewortelingsgroei, maar ook de dichtheid, of beter gezegd het luchtgehalte. Het luchtgehalte bij een vochtspanning van $-50 \mathrm{~cm}$ H2O is een maat voor de aeratie.
} 
Tabel 3.9 geeft de diepte weer waarop de aangegeven indringweerstand wordt overschreden. De indringweerstand $>3 \mathrm{MPa}$ is de formele grens waarop nog net wortelgroei mogelijk is. In dit onderzoek is uitgegaan van 2,5 MPa, omdat de grenswaarde per gewas kan verschillen en ook andere aspecten zoals aeratie een rol kunnen spelen. Een agressief wortelend gewas als sorghum is bijvoorbeeld minder gevoelig voor bodemverdichting dan tarwe. Tijdens de veldschouw van april 2019 is per veld de aangetroffen beworteling beschreven. Voor blok 1 en 3 was dit $70 \mathrm{~cm}$ en voor blok 14 en 16 was dit $80 \mathrm{~cm}$. Dit komt ongeveer overeen met de diepten behorende bij indringweerstanden van $3 \mathrm{MPa}$.

De potentiële bewortelingsdiepten, ofwel de worteldiepten in niet-gelimiteerde omstandigheden, zijn per gewas weergegeven in Tabel 3.10. De kleinste diepte - óf gelimiteerd door het gewas zelf (Tabel 3.10) óf gelimiteerd door de diepte van de indringweerstand (Tabel 3.9) - is als potentiële worteldiepte in de SWAP-WOFOST-modellering aangehouden. Zo is bijvoorbeeld in de SWAP de potentiële bewortelingsdiepte op blok 16 met zomergerst $75-80 \mathrm{~cm}$ en voor pootaardappel op datzelfde perceel $50 \mathrm{~cm}$, waarbij zomergerst gelimiteerd wordt door de indringweerstand en pootaardappel door zijn potentiële (ongelimiteerde) bewortelingsdiepte.

Tabel 3.9 Overzicht van de diepte warop de aangegeven indringweerstand $I_{w}$ wordt overschreden.

\begin{tabular}{|c|c|c|c|c|}
\hline Locatie & Bewerking & $\begin{array}{l}\text { Diepte } \\
\text { IW }>2 \mathrm{MPa} \\
\mathrm{cm}-\mathrm{mv}\end{array}$ & $\begin{array}{l}\text { Diepte } \\
\text { IW > } 3 \mathrm{MPa} \\
\text { cm-mv }\end{array}$ & $\begin{array}{l}\text { Diepte } \\
\text { IW } \approx 2.5 \mathrm{MPa} \\
\mathrm{cm}-\mathrm{mv}\end{array}$ \\
\hline Veld 4, Blok3 & NKG20 & 40 à 50 & 80 & 70 \\
\hline Veld 6, Blok14 & NKGO & ca 40 & ca 70 & 55 \\
\hline
\end{tabular}

Tabel 3.10 Overzicht potentiële (ongelimiteerde) bewortelingsdiepte voor verschillende gewassen.

\begin{tabular}{ll} 
Gewas & Bewortelingsdiepte \\
Zomergerst & 125 \\
\hline Suikerbiet & 120 \\
\hline Wintertarwe & 125 \\
\hline Zaaiuien & 30 \\
\hline Pootaardappel & 50 \\
\hline Sperziebonen & 100 \\
\hline
\end{tabular}

\subsubsection{Veldmetingen opbrengsten en beoordeling teelten}

De eerste jaren (2009-2015) waren de gewasopbrengsten van het NKG-systeem lager dan die van het reguliere grondbewerkingssysteem (ploegen). De laatste jaren (vanaf 2018) zijn de verschillen in gewasopbrengsten kleiner of vallen zelfs in het voordeel van NKG uit. De resultaten van de SWAPberekeningen zijn gegeven in paragraaf 3.3.4. 
Tabel 3.11 Veldgegevens van de opbrengsten (marktbaar) en verschil in opbrengst voor veld 6, blok 14 (NKG0) en 16 (Ploeg25) op perceel j9-6.

\begin{tabular}{|c|c|c|c|c|c|}
\hline Blok & Gr.bew & Jaar & Gewas & Marktbare opbrengst_kg/ha & Verschil NKG t.O.V. Ploegen \\
\hline 14 & NKG0 & \multirow[t]{2}{*}{2009} & \multirow[t]{2}{*}{ Suikerbieten } & 17131 & \multirow[t]{2}{*}{$-11 \%$} \\
\hline 16 & Ploeg25 & & & 19342 & \\
\hline 16 & Ploeg25 & 2010 & Wintertarwe & 11296 & $6 \%$ \\
\hline 14 & NKGO & 2011 & Zaaiui & 79056 & $-9 \%$ \\
\hline 14 & NKGO & \multirow[t]{2}{*}{2012} & \multirow[t]{2}{*}{ Aardappel } & 33950 & \multirow[t]{2}{*}{$-8 \%$} \\
\hline 16 & Ploeg25 & & & 36707 & \\
\hline 14 & NKG0 & \multirow[t]{2}{*}{2013} & \multirow[t]{2}{*}{ Suikerbieten } & 17270 & \multirow[t]{2}{*}{$-4 \%$} \\
\hline 16 & Ploeg25 & & & 18070 & \\
\hline 16 & Ploeg25 & 2015 & Zaaiui & 70841 & $-4 \%$ \\
\hline 14 & NKG0 & \multirow[t]{2}{*}{2017} & \multirow[t]{2}{*}{ Suikerbieten } & 21440 & \multirow[t]{2}{*}{$2 \%$} \\
\hline 16 & Ploeg25 & & & 20931 & \\
\hline 14 & NKGO & \multirow[t]{2}{*}{2018} & \multirow[t]{2}{*}{ Zomergerst } & 7723 & \multirow[t]{2}{*}{$8 \%$} \\
\hline 16 & Ploeg25 & & & 7175 & \\
\hline 14 & NKGO & \multirow[t]{2}{*}{2019} & \multirow[t]{2}{*}{ Conservenerwt } & 3110 & \multirow[t]{2}{*}{$8 \%$} \\
\hline 16 & Ploeg25 & & & 2882 & \\
\hline
\end{tabular}

Over het algemeen is het goed mogelijk om een systeem van niet-kerende grondbewerking in te passen in een gangbaar of biologisch akkerbouwbedrijf. De ervaringen in Lelystad tot 2016 zijn in grote lijnen (Hoek et al., 2019; Crittenden, 2015):

1. NKG20 geeft voor de meeste gewassen na zeven jaar vergelijkbare opbrengsten als Ploegen25.

2. Bodemweerbaarheid is groter in NKG. Invloed van groenbemester wordt nader onderzocht.

3. Aggregaatstabiliteit is hoger in NKG.

4. Biodiversiteit regenwormen is groter bij NKG.

5. Opbouw van stikstof is hoger in NKG. N-benutting en uitspoeling behoeven nader onderzoek. Een verschil dat nog niet eerder zo sterk naar voren kwam, is het verschil in stikstofdynamiek tussen ploegen en niet-kerende grondbewerking. Er wordt van uitgegaan dat er in een NKG-systeem $30 \mathrm{~kg} \mathrm{~N}$ per ha extra nodig is om eenzelfde opbrengst te kunnen halen gedurende de eerste jaren na toepassen van dit grondbewerkingssysteem.

6. Er is een tendens dat de uitstoot van broeikasgassen in gereduceerde grondbewerking lager is, maar dit is niet consistent. In het gangbare bedrijfssysteem is een reductie in brandstofverbruik mogelijk, in het biologische bedrijfssysteem is deze verwaarloosbaar.

7. Onkruiddruk wordt hoger bij NKG.

De verschillen in de metingen van de bulkdichtheid en organische stof bij de verschillende systemen van grondbewerking zijn ook vanuit de literatuur bekend (Amami et al., 2021). 


\subsection{Vredepeel basisgegevens en veldmetingen}

\subsubsection{Bodemopbouw en hydrofysische bodemparameters}

In Tabel 3.12 zijn gegevens van de verschillende plots opgenomen die tijdens de veldschouw op 4 mei 2020 zijn aangetroffen. De GHG en GLG bevinden zich respectievelijk op 70 en $140 \mathrm{~cm}-\mathrm{mv}$.

Tabel 3.12 Kenmerken plots op basis van de veldschouw (mei 2020).

\begin{tabular}{llllllllll} 
Plot & Bewerking & $\begin{array}{l}\text { Maaiveld } \\
(\mathrm{m}+\mathrm{NAP})\end{array}$ & $\mathrm{X}$ & $\mathrm{Y}$ & $\begin{array}{l}\text { GHG } \\
(\mathrm{cm}-\mathrm{mv})\end{array}$ & $\begin{array}{l}\text { GLG } \\
(\mathrm{cm}-\mathrm{mv})\end{array}$ & Gt & $\begin{array}{l}\text { Worteldiepte } \\
(\mathrm{cm})\end{array}$ & Drainage \\
\hline 40 & NKG15 & 27.43 & 186922 & 394852 & 70 & 140 & VIo & 55 & $\mathrm{Y}$ \\
\hline 48 & Ploeg30 & 27.41 & 186905 & 394852 & 70 & 140 & VIo & 60 & Y \\
\hline
\end{tabular}

In Tabel 3.13 zijn enkele laboratoriumbepalingen weergegeven. Bijlage 7 geeft de bodemprofielen en veldschattingen. De bodem bestaat uit leemarm matig fijn zand, naar beneden toe afnemend in humusgehalte.

Tabel 3.13 In het laboratorium gemeten droge bulkdichtheid, granulaire samenstelling en organischestofgehalte per bodemlaag.

\begin{tabular}{|c|c|c|c|c|c|c|c|c|}
\hline Monster & $\begin{array}{l}\text { droge } \\
\text { bulkdichtheid } \\
\mathrm{kg} / \mathrm{m} 3\end{array}$ & M50 & lutum $\%$ & silt $\%$ & leem $\%$ & Os\% & textuur naam & Bouwsteen SWAP \\
\hline NKG15 33-43cm & 1563 & 182 & 2.3 & 2.7 & 5.0 & 2.6 & $\begin{array}{l}\text { matig humeus } \\
\text { leemarm matig fijn zand }\end{array}$ & NKG_B01m \\
\hline NKG15 65-75cm & 1722 & 165 & 0.2 & 1.0 & 1.2 & 0.3 & $\begin{array}{l}\text { uiterst humusarm } \\
\text { leemarm matig fijn zand }\end{array}$ & NKG_O01d \\
\hline Ploeg30 8-18cm & 1369 & 175 & 2.0 & 3.4 & 5.4 & 5.1 & $\begin{array}{l}\text { zeer humeus } \\
\text { leemarm matig fijn zand }\end{array}$ & PI_B010 \\
\hline Ploeg30 33-43cm & 1523 & 173 & 1.4 & 4.2 & 5.6 & 3.2 & $\begin{array}{l}\text { matig humeus } \\
\text { leemarm matig fijn zand }\end{array}$ & PI_B01m \\
\hline
\end{tabular}

Tabel 3.14 geeft de uit de laboratoriummetingen afgeleide Mualem-Van Genuchten (MvG-)parameters. Daarnaast is op basis van klassekenmerken een Staringbouwsteennummer afgeleid. Deze code is in het tweede deel van de monsternaam weergegeven, gevolgd door de index voor ondiep, middeldiep en diep. Voor de berekeningen is uitgegaan van de in het laboratorium gemeten en daarvan afgeleide MvG-parameters. De gemeten verzadigde waterdoorlatendheid $\mathrm{Ksm}$ kan sterk variëren voor de verschillende monsters en over de verschillende percelen, vooral door het al dan niet voorkomen van macroporiën ten gevolge van bijvoorbeeld wormen, krimpscheuren of aggregaatvorming. De modelparameter Ksf volgt de dwingende vorm van het MvG-model en kan vooral voor de verzadigde waterdoorlatendheid behoorlijk afwijken van de gemeten doorlatendheid $\mathrm{Ksm}$.

De bijbehorende Mualem-Van Genuchten-curves van de waterretentie- en waterdoorlatendheidskarakteristieken zijn weergegeven in Figuur 3.4. 
Tabel 3.14 Mualum-van Genuchten-parameters, afgeleid van de hydrofysische metingen aan de bodemmonsters. Het tweede deel van de monstercode is weergegeven in de kolommen van Figuur 3.4.

\begin{tabular}{|c|c|c|c|c|c|c|c|c|}
\hline Monster & $\begin{array}{l}\mathrm{Ksm} \\
(\mathrm{cm} / \mathrm{d})\end{array}$ & $\begin{array}{l}\mathrm{WCr} \\
\left(\mathrm{cm} 3 / \mathrm{cm}^{3}\right)\end{array}$ & $\begin{array}{l}\text { WCs } \\
(\mathrm{cm} 3 / \mathrm{cm} 3)\end{array}$ & $\begin{array}{l}\text { Alpha } \\
(1 / \mathrm{cm})\end{array}$ & $\begin{array}{l}N \\
(-)\end{array}$ & $\begin{array}{l}M \\
(-)\end{array}$ & $\begin{array}{l}\text { Lambda } \\
(-)\end{array}$ & $\begin{array}{l}\text { Ksf } \\
(\mathrm{cm} / \mathrm{d})\end{array}$ \\
\hline NKG_B010 & 102.8 & 0.026559 & 0.385000 & 0.017889 & 1.719356 & 0.418387 & 0.643962 & 13.590 \\
\hline NKG_O1d & 142.5 & 0.015624 & 0.285655 & 0.015017 & 3.664843 & 0.727137 & 0.000100 & 8.225 \\
\hline PI_B010 & 82.2 & 0.024579 & 0.432695 & 0.025943 & 1.550605 & 0.355091 & 0.000100 & 52.543 \\
\hline PI_01d & 150.0 & 0.005144 & 0.306243 & 0.017812 & 3.085582 & 0.675912 & 0.868439 & 8.752 \\
\hline
\end{tabular}

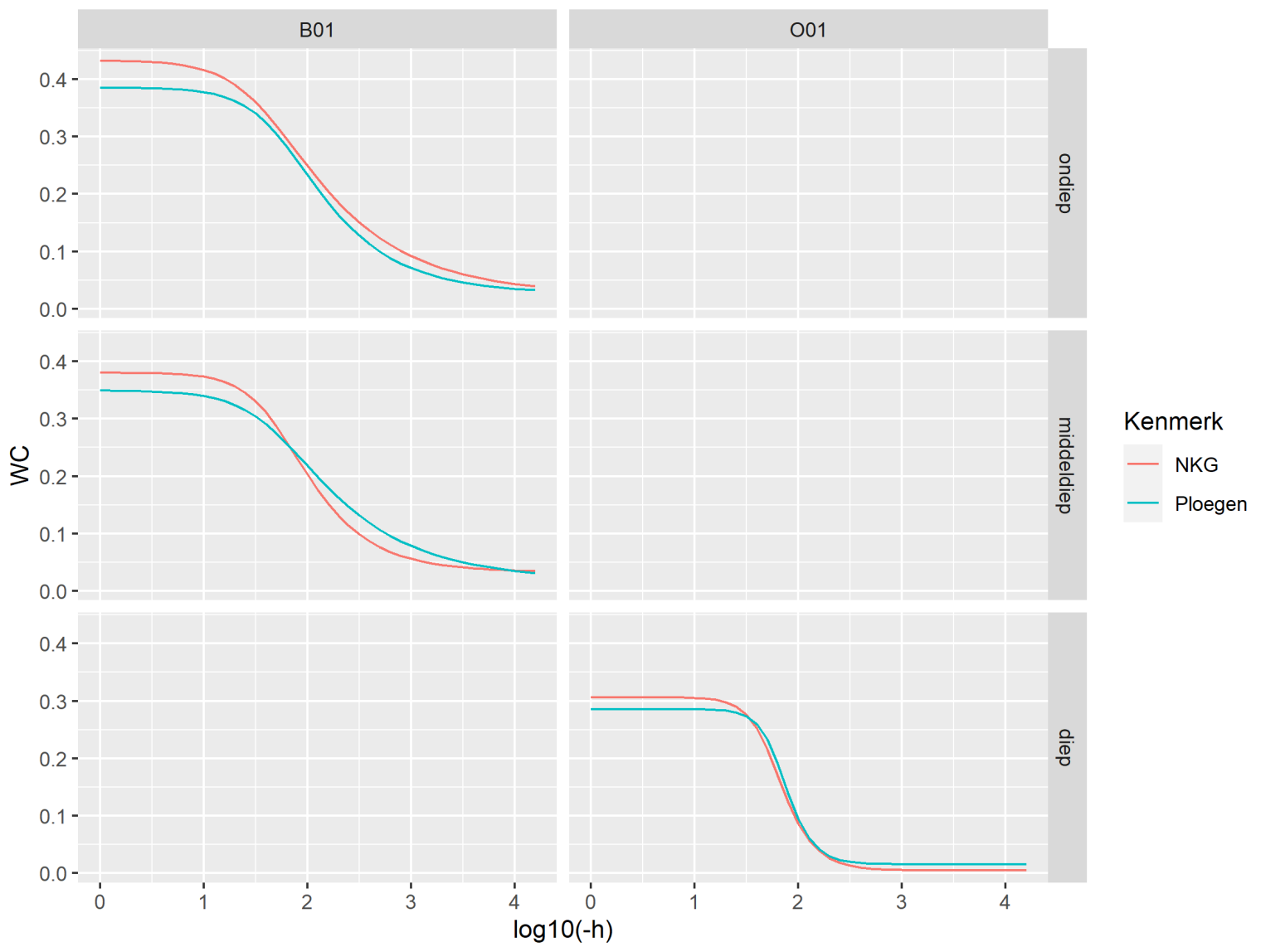

Figuur 3.4 Overzicht van de gemeten hydrofysische Mualem-Van Genuchten-

retentiekarakteristieken van de verschillende lagen zoals opgenomen in Tabel 3.14. De kolomnamen zijn overeenkomstig het rechterdeel van de monstercode in de tabel. 


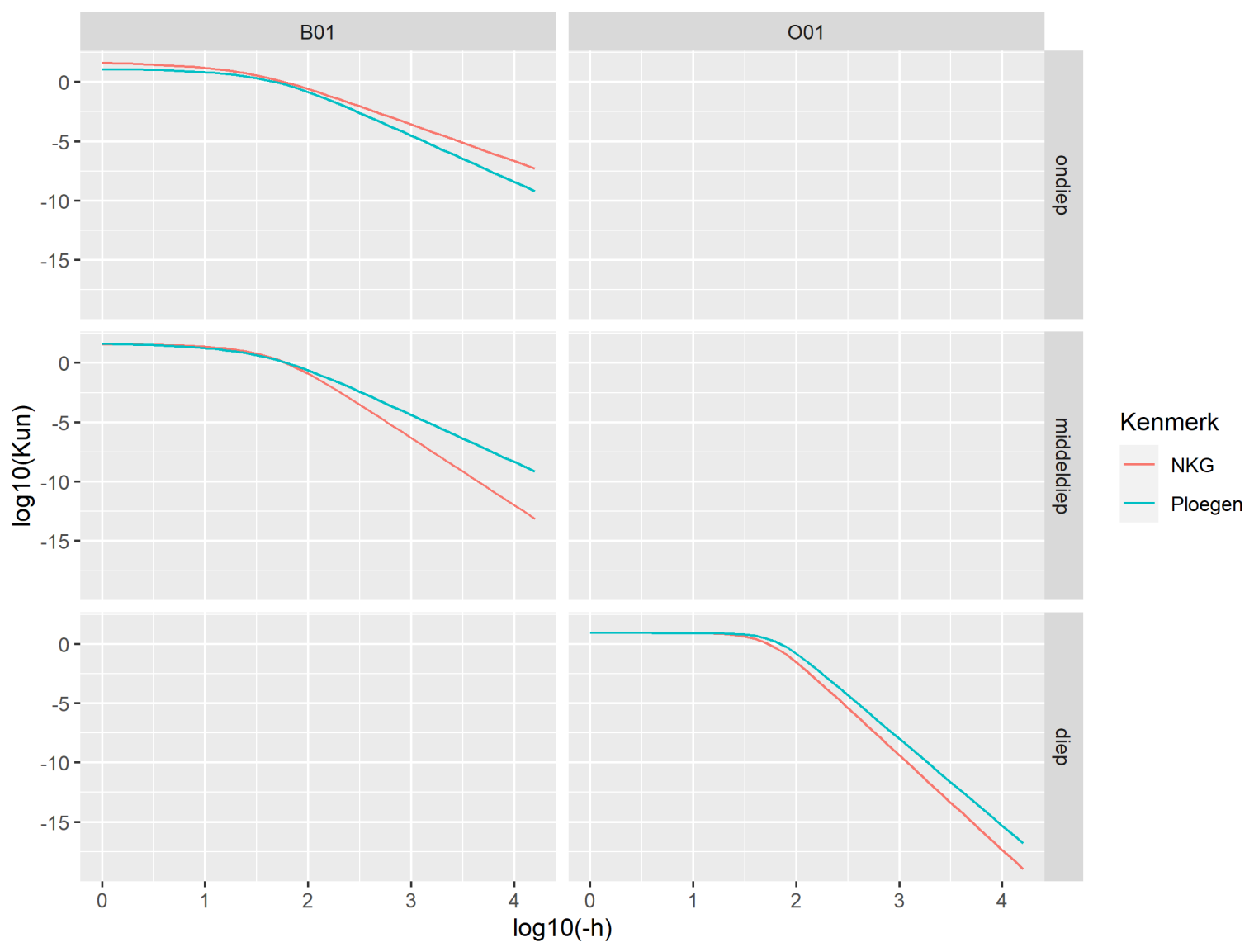

Figuur 3.5 Overzicht van de gemeten hydrofysische Mualem-Van Genuchtenwaterdoorlatendheidskarakteristieken van de verschillende lagen zoals bedoeld in Tabel 3.14. De kolomnamen zijn overeenkomstig het rechterdeel van de monstercode in de tabel.

In Tabel 3.15 is een overzicht gegeven van de gemeten hydrofysische kenmerken die voor directe beoordeling in aanmerking komen in het hoofdstuk Discussie.

Tabel 3.15 Overzicht hydrofysische bodemeigenschappen Vredepeel. In rood de waarden die niet aan de limiet voldoen. Cursief staan waarden voor het luchtgehalte bij een vochtspanning van $-50 \mathrm{~cm}$ H2O (i.e. gemiddelde bij een vochtspanning van -30 en $-70 \mathrm{~cm} \mathrm{H2O}$ ).

\begin{tabular}{|c|c|c|c|c|c|c|c|c|c|}
\hline \multirow[t]{2}{*}{ Plek } & \multicolumn{2}{|c|}{$\begin{array}{l}\text { Monsterdiepte } \\
(\mathrm{cm}-\mathrm{mv})\end{array}$} & \multirow{2}{*}{$\begin{array}{l}\text { Ksat } \\
{[\mathrm{cm} / \mathrm{d}]}\end{array}$} & \multirow{2}{*}{$\begin{array}{l}\text { BD- } \\
\text { mediaan } \\
{[\mathrm{g} / \mathrm{cm} 3]}\end{array}$} & \multirow{2}{*}{$\begin{array}{l}\text { Lutum } \\
{[\%]}\end{array}$} & \multirow{2}{*}{$\begin{array}{l}\text { OS } \\
{[\%]}\end{array}$} & \multirow{2}{*}{$\begin{array}{l}\text { Volume } \\
\text { poriën } \\
{[\%]}\end{array}$} & \multirow{2}{*}{$\begin{array}{l}\text { Vol. lucht } \\
-50 \mathrm{~cm} \mathrm{H2O} \\
{[\%]}\end{array}$} & \multirow{2}{*}{$\begin{array}{l}\text { Vol. lucht }-100 \\
\mathrm{~cm} H 20 \\
{[\%]}\end{array}$} \\
\hline & van & tot & & & & & & & \\
\hline \multirow{2}{*}{$\begin{array}{l}\text { Ploeg30 } \\
\text { (plot 48) }\end{array}$} & 8 & 18 & 82.2 & 1.369 & 2.0 & 5.1 & 46.4 & 16.3 & 28.3 \\
\hline & 33 & 43 & 112.2 & 1.522 & 1.4 & 3.2 & 41.3 & 12.2 & 21.6 \\
\hline \multirow{3}{*}{$\begin{array}{l}\text { NKG15 } \\
\text { (plot 40) }\end{array}$} & 8 & 18 & 102.8 & 1.419 & 2.0 & 3.7 & 45.1 & 15.5 & 29.3 \\
\hline & 33 & 43 & 238.9 & 1.566 & 2.3 & 2.6 & 39.9 & 14.3 & 22.0 \\
\hline & 65 & 75 & 142.5 & 1.722 & 0.2 & 0.3 & 35.1 & 13.3 & 25.8 \\
\hline
\end{tabular}

\subsubsection{Grondwaterstandmetingen (2017-2020)}

Grondwaterstanden zijn gemeten op perceel 27.1b met een peilbuis met een filterdiepte $160-210 \mathrm{~cm}$ -mv (Figuur 3.7). Er zijn grote verschillen te zien gedurende de zomers van de weergegeven jaren: 2018 heeft vanaf begin juli $\mathrm{t} / \mathrm{m}$ begin december lage grondwaterstanden; 2019 heeft een korte periode met grondwaterstanden lager dan $150 \mathrm{~cm}$-mv; 2020 toont behalve in het winterseizoen ook in de zomer twee perioden met heel hoge grondwaterstanden. De piek rond 20 juni 2020 is gecontroleerd aan de 
hand van de tensiometerdata. De tensiometers blijken goed de grondwaterstand aan te geven. De grondwaterstanden ter plaatse van de plots 40 en 48 zijn geschat door de drukhoogte op $64 \mathrm{~cm}-\mathrm{mv}$ bij de meetdiepte op te tellen (Figuur 3.6).

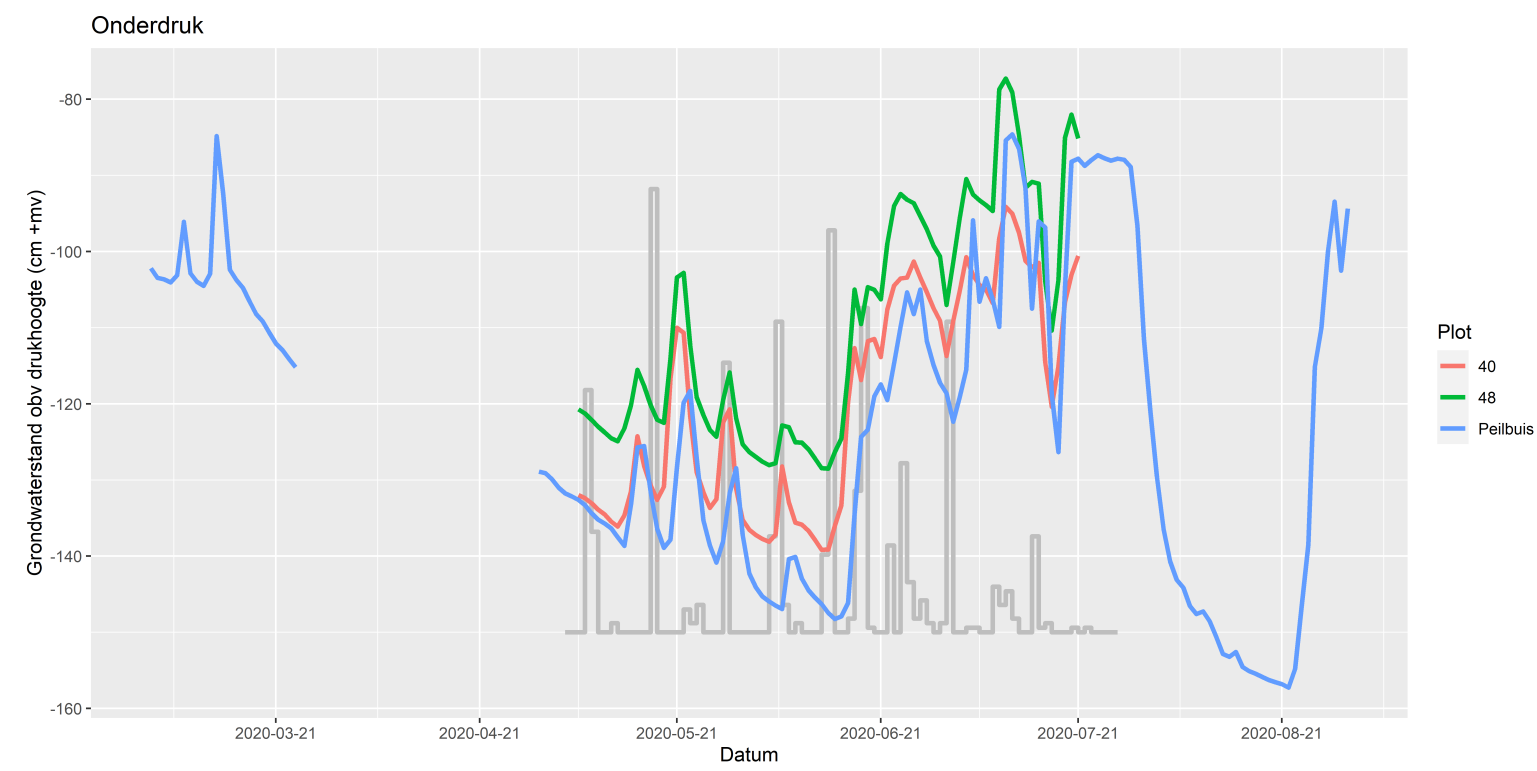

Figuur 3.6 Grondwaterstanden Vredepeel: de peilbuis geeft de gemeten waarden op perceel 27.1b. De grondwaterstanden ter plaatse van de plots 40 (NKG15) en 48 (Ploeg30) zijn berekend aan de hand van de drukhoogte op $64 \mathrm{~cm}-\mathrm{mv}$. In grijs zijn de neerslagevents weergegeven (tipping bucket).

De dynamiek in de lijnen van de plots 40 en 48 komt goed overeen met die van de metingen in de grondwaterstandbuis. De grondwaterstanden reageren duidelijk op de neerslagevents.

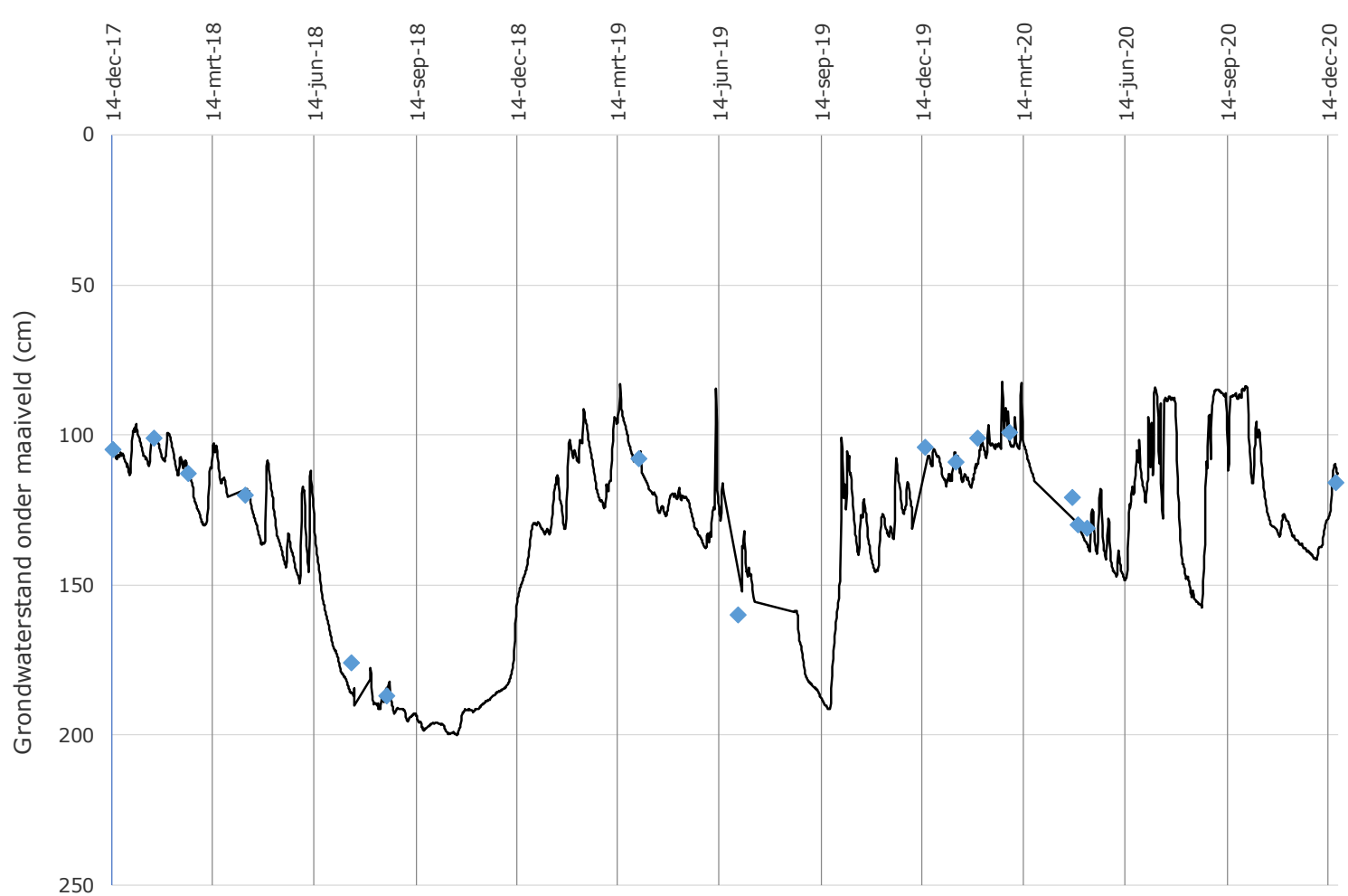

Figuur 3.7 Grondwaterstanden op perceel 27.1b (diver = zwarte lijn; handmetingen = blauwe stippen). 


\subsubsection{Neerslag, verdamping en beregening}

De locatie ligt dicht bij de KNMI-meteostations Volkel en Arcen. Het dichtstbij gelegen neerslagstation is IJsselstein. Op het agrarische proefstation is een DACOM-meetstation voor de neerslag aanwezig en wordt een regenmeter (beker) dagelijks uitgelezen. Tevens zijn bij Meteobase gegevens opgevraagd die gebaseerd zijn op radargegevens. Deze gegevens zijn beschikbaar tot en met oktober 2020 en komen goed overeen met de gegevens van KNMI-station Volkel. De gegevens zijn uitgebreid weergegeven in Tabel 3.16. Deze geeft voor de verschillende informatiebronnen voor 2020 een variatie in de jaarneerslag van 602 tot $702 \mathrm{~mm}$ en voor de zomer 224 tot $288 \mathrm{~mm}$. Dit zijn aanzienlijke verschillen. Dit geldt zeker voor het neerslagoverschot (neerslag minus verdamping).

De keuze voor een van de bronnen is afhankelijk van 1) de locatie van de metingen en 2) de betrouwbaarheid van de metingen. De ervaring leert dat lokaal gemeten met een tipping bucket altijd goed gecontroleerd moeten worden vanwege soms niet goed functionerende onderdelen. Voor het jaar 2020 zijn de gegevens van DACOM gebruikt, omdat deze direct op de locatie meet en plausibele waarden laat zien: deze komen qua jaar- en zomerhoeveelheden goed overeen met de Vredepeelmeting. De reeks van Vredepeel laat een totale neerslaghoeveelheid van circa $100 \mathrm{~mm}$ zien in juni en rond begin oktober. Volgens DACOM valt er begin oktober ongeveer $50 \mathrm{~mm}$.

Tot en met 2019 zijn de gegevens van Volkel gebruikt in de SWAP-simulaties: deze jaren zijn in de simulaties gebruikt als inloopjaren.

Tabel 3.16 Jaarneerslag 2020 voor verschillende stations/databronnen.

\begin{tabular}{llll} 
Locatie & Neerslag jaar $(\mathrm{mm})$ & Zomer $(\mathrm{mm})$ & Opmerking \\
Volkel & 702 & 288 & Op circa $20 \mathrm{~km}$ afstand \\
\hline IJsselstein & 685 & 259 & Op circa $7 \mathrm{~km}$ afstand \\
\hline Meteobase & & 264 & Niet compleet \\
\hline DACOM & 602 & 224 & Op locatie \\
\hline Vredepeel meteostation & 632 & 239 & Op locatie \\
\hline
\end{tabular}

\section{Beregening}

De percelen zijn in 2020 drie keer beregend ( 8 mei, 17 mei en 28 mei) met 25 à 30 mm per keer. Deze beregeningshoeveelheden zijn meegenomen in de simulatie met SWAP.

Ook in de omgeving zal waarschijnlijk beregend zijn. De onttrekking van water hiervoor kan de grondwaterstanden op de proefvelden (sterk) verlagen. De grondwaterstanden bij de percelen en de grondwaterstand bij de peilbuis kunnen hierdoor van elkaar afwijken.

\subsubsection{Oppervlaktewaterstanden, buisdrainage en maaiveldafvoer}

Op de locatie is drainage aanwezig:

- Drainage op onderlinge afstand van $6 \mathrm{~m}$

- Richting van zuid naar noord

- Diepte 80-100 cm -mv

Oppervlaktewaterstanden zijn niet gemeten. In de sloten wordt in verband met de bewerkbaarheid van het land het slootpeil soms verlaagd. Gedurende het seizoen fluctueert het slootpeil afhankelijk van de grondwaterstand. Het peil in het Peelkanaal staat vrij hoog (mondelinge mededeling H. Verstegen, Proefboerderij Vredepeel).

\subsubsection{Geohydrologie}

De ondiepe bodem bestaat grotendeels uit matig fijn zand. Op 2,5 tot $3 \mathrm{~m}$ is in boringen in de buurt een leemlaag met ook veen aangetroffen. Daaronder bevinden zich tot grote diepte eveneens zandlagen met op 10 tot $24 \mathrm{~m}$-mv een grindlaag (Bijlage 9). 


\subsubsection{Geteelde gewassen}

In 2020 is op de proefvelden Zomergerst geteeld met Japanse Haver als groenbemester (Tabel 3.17). Het vanggewas stond in dat jaar tot begin december op het land. In de SWAP-simulatie is als groeiperiode uitgegaan van 1 september tot 1 december.

De Groenmonitor geeft informatie over de ontwikkeling van gewassen. Deze gegevens zijn opgenomen in Bijlage 10. Hieruit blijkt dat omtrent begin mei het gewas gesloten was en halverwege juli geoogst is.

Tabel 3.17 Gewasteelt Vredepeel in 2020.

\begin{tabular}{lll} 
Systeem & NKG15 & Ploeg30 \\
Perceel & 27.1 a plot 40 & 27.1 plot 48 \\
\hline Gewas & Zomergerst & Zomergerst \\
\hline Ras & KWS Irina & KWS Irina \\
\hline Zaaidatum & $28-$ mrt-20 & $28-$ mrt-20 \\
\hline Oogstdatum & $21-j u l-20$ & $21-j u l-20$ \\
\hline Opbrengst korrel (kg/ha) & 5.951 & 8.008 \\
\hline Werkelijk vochtgehalte (\%) & 14,1 & 13,2 \\
\hline Hectolitergewicht (kg) & 63,1 & 64,8 \\
\hline Duizendkorrelgewicht (g) & 56,0 & 56,7 \\
\hline Gecorrigeerde korrelopbrengst naar 15\% vocht(kg/ha) & 6.014 & 8.177 \\
\hline Opbrengst stro (ton/ha) & 1,9 & 2,5 \\
\hline
\end{tabular}

\subsubsection{Veldmetingen drukhoogte}

In Tabel 3.18 zijn de nummers en de diepten van de tensiometers opgenomen die in mei 2020 op de percelen zijn geplaatst. De drukhoogten zijn gemeten op diepten van 17 tot $64 \mathrm{~cm}-\mathrm{mv}$.

Tabel 3.18 Tensiometergegevens per plot en op verschillende diepten.

\begin{tabular}{ll} 
Tensiometer nummer & Diepte Sensor [cm-mv] \\
\hline Plot 40 (NKG15) & 17 \\
\hline 06010 & 46 \\
\hline 06009 & 46 \\
\hline 06154 & 64 \\
\hline 06155 & \\
\hline Plot 48 (Ploeg30) & 17 \\
\hline 06148 & 41 \\
\hline 06149 & 41 \\
\hline 06150 & 64 \\
\hline 06151 & \\
\hline
\end{tabular}

In Bijlage 11 zijn de metingen van de tensiometers weergegeven. De metingen van de drukhoogte zijn betrouwbaar geacht tot het moment dat de bodem te droog wordt en de tensiometers doorslaan. De betrouwbare metingen zijn aangegeven met een doorgetrokken lijn.

\subsubsection{Beworteling en indringweerstand}

In het veld is de worteldiepte van het gewas bepaald. Plot 48 (Ploeg30) heeft duidelijk diepere wortels dan plot 40 (NKG15). De bulk van de wortels zit in het geploegde perceel tot een diepte van circa $40 \mathrm{~cm}$ en in het NKG-perceel tot een diepte van circa $30 \mathrm{~cm}$. Deze worteldiepten zijn in de SWAPmodellering gebruikt. 
Tabel 3.19 Worteldiepte plot 40 (NKG15). De getallen geven de aantallen wortels per oppervlakte van $10 \times 10 \mathrm{~cm}$ weer. Bij de wortelopname is opgemerkt dat de bulk in de bovenste $12 \mathrm{~cm}$ zit.

\begin{tabular}{|c|c|c|c|c|}
\hline Diepte & Raster 1 & Raster 2 & Raster 3 & Gemiddeld \\
\hline 0 tot -10 & 45 & 51 & 50 & 49 \\
\hline-10 tot -20 & 31 & 37 & 47 & 38 \\
\hline-30 tot -40 & 7 & 2 & 3 & 4 \\
\hline-40 tot -50 & 0 & 1 & 1 & 1 \\
\hline
\end{tabular}

Maximale worteldiepte SWAP $30 \mathrm{~cm}$

Tabel 3.20 Beworteling plot 48 (Ploeg30). De getallen geven de aantallen wortels per oppervlakte van $10 \times 10 \mathrm{~cm}$ weer. Bij de wortelopname is opgemerkt dat de bulk in de bovenste $15 \mathrm{~cm}$ zit.

\begin{tabular}{|c|c|c|c|c|}
\hline Diepte & Raster 1 & Raster 2 & Raster 3 & Gemiddeld \\
\hline 0 tot -10 & 48 & 48 & 50 & 49 \\
\hline-10 tot -20 & 47 & 53 & 48 & 49 \\
\hline-30 tot -40 & 33 & 16 & 11 & 20 \\
\hline-40 tot -50 & 1 & 0 & 2 & 1 \\
\hline
\end{tabular}

Maximale worteldiepte SWAP $40 \mathrm{~cm}$

Per gewas is er een maximale of potentiële bewortelingsdiepte. Daarnaast is er een bodemgebonden maximum, die mede afhankelijk is van de indringweerstand: bij Iw > 2 MPa wordt de beworteling beperkt, maar niet verhinderd. Bij MPa $>3$ wordt beworteling in belangrijke mate verhinderd. De mediane waarden van de indringweerstand van 2.0 à 3.0 MPa worden overschreden tussen 25 en $40 \mathrm{~cm}-\mathrm{mv}$. Dit komt overeen met de waarnemingen van de wortelontwikkeling. 


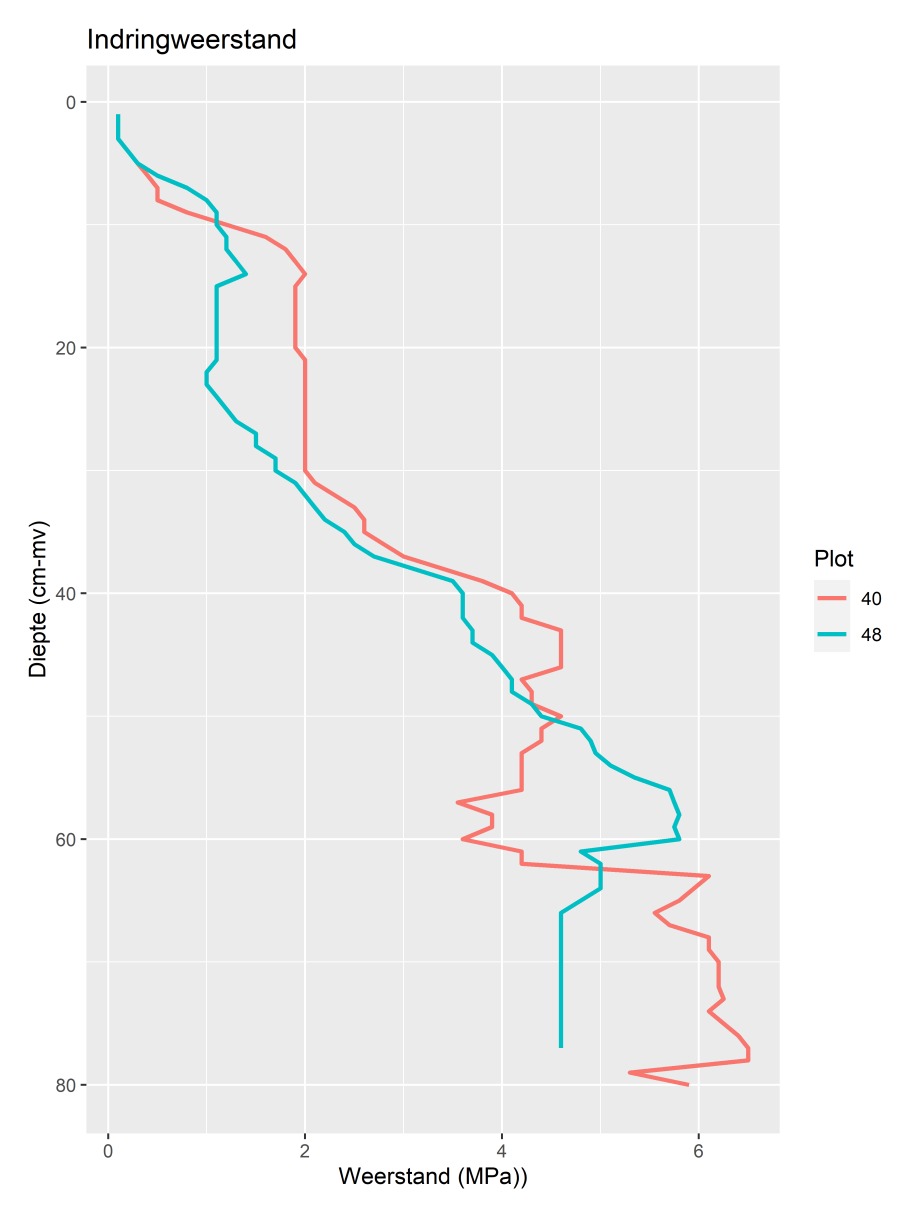

Figuur 3.8 Indringweerstand (mediaan) op 29 april 2020 op plot 40 (NKG15) en plot 48 (Ploeg30).

\subsubsection{Veldmetingen opbrengsten en beoordeling teelten}

De opbrengsten zijn weergegeven in Bijlage 12. De opbrengstverschillen tussen NKG15 en Ploeg30 zijn in het meetjaar 2020 voor ondergrondverdichting voornamelijk het gevolg van een stuifzandincident in het vroege voorjaar. Zij kunnen dus niet goed gebruikt worden bij de verificatie van de resultaten van het SWAP-WOFOST-model voor dat jaar.

Over de jaren heen variëren de opbrengsten aanzienlijk. In de figuren van de bijlage is te zien dat de opbrengst bij 'Biologisch NKG' vanaf 2015 de opbrengsten van de andere bewerkingen benadert. Het is bekend dat de NKG enige tijd nodig heeft om zich in te stellen (aanpassing bodemleven). Interessant is om te zien dat de combinatie Biologisch en Ploegen een lagere opbrengst heeft dan Biologisch en NKG.

\subsection{Lelystad SWAP: kalibratie en opbrengsten}

\subsubsection{Kalibratie en validatie}

Bij de simulatie was geen kalibratie nodig, omdat de gesimuleerde drukhoogten op basis van de ingevoerde basisgegevens al direct een goede overeenkomst vertoonden met de gemeten drukhoogten. Opgemerkt wordt dat de drukhoogte alleen bekend is voor een korte en relatief natte periode van half oktober tot begin december 2019.

\subsubsection{Grondwaterstanden}

In Figuur 3.9 zijn de gesimuleerde grondwaterstanden weergegeven. Grondwaterstanden zijn niet gemeten; wel is op basis van hydromorfe kenmerken bij het zetten van boringen een GHG en GLG 
afgeleid (Tabel 3.1) van circa $100 \mathrm{~cm}-\mathrm{mv}$ en $150 \mathrm{~cm}$-mv. Dit komt redelijk overeen met de gegevens uit de figuur, waarbij bedacht moet worden dat 2018 en 2019 droog waren en de jaren 2015 t/m 2017 normaler verlopen.

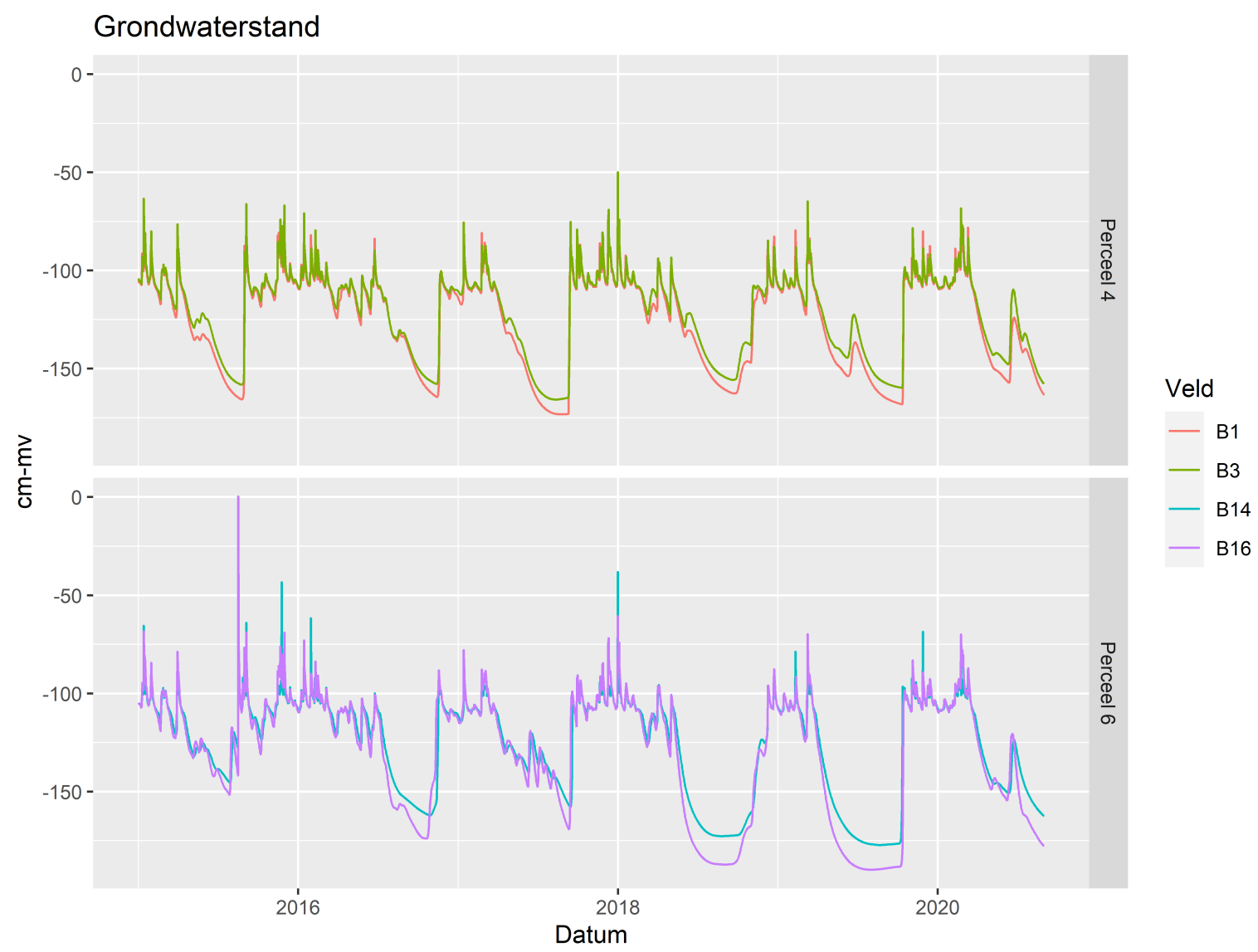

Figuur 3.9 Berekende grondwaterstanden (Blok 1: Ploeg15, Blok 3: NKG20, Blok 14: NKG0, Blok 16: Ploeg25).

\subsubsection{Drukhoogte}

Figuur 3.10 geeft de vergelijkingen van meetgegevens met de simulaties voor de blokken 14 (NKG0 = zonder cultiveren) en 16 (Ploeg25). Hieruit blijkt dat de simulatie de variaties in de drukhoogte heel goed volgen. Om voor dezelfde diepten beide blokken te kunnen vergelijken, is in Bijlage 13 ook in Figuur B13.2 opgenomen. Hieruit blijkt duidelijk dat blok 14 (B14-NKG0) lagere pF-waarden (natter) heeft dan blok 16 (B16-Ploeg25) en tevens een hogere dynamiek. 


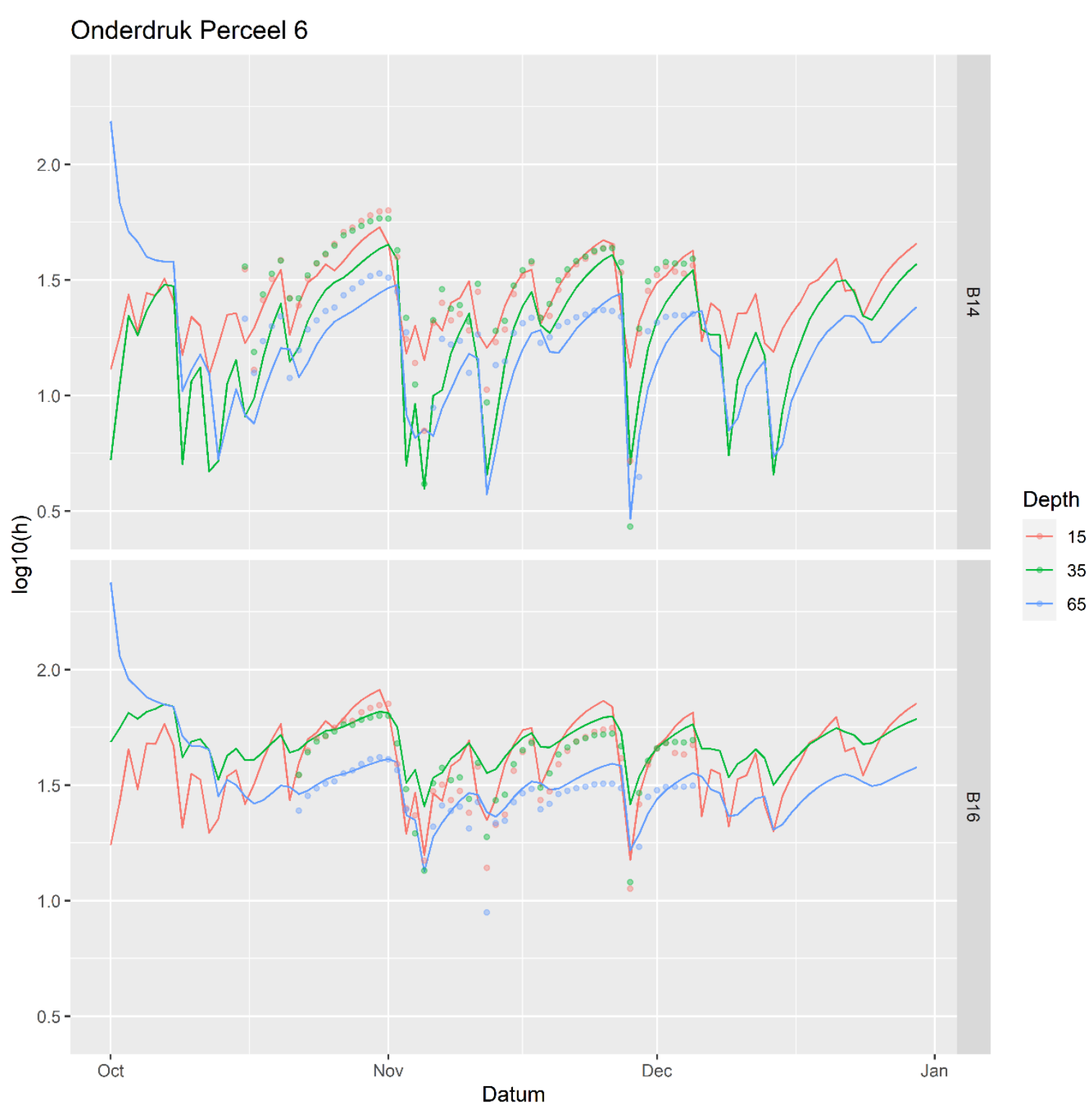

Figuur 3.10 Vergelijking metingen met modelresultaten voor blok 14 (NKG20) en 16 (Ploeg25).

\subsubsection{Beoordeling modellering}

De simulatie van de GHG en de GLG lijkt redelijk goed te kloppen met de waarnemingen. Ook de gemeten drukhoogten konden goed worden gereproduceerd met SWAP. Er is daarom vertrouwen in het model om scenario's door te kunnen rekenen.

De betrouwbaarheid kan wel verhoogd worden door uitbreiding van metingen met tensiometers naar een zomerperiode om ook voor drogere perioden de simulaties te kunnen toetsen (de tensiometermetingen zijn nu alleen uitgevoerd gedurende een korte periode in een nattere situatie). De kalibratie/validatie en simulatie van het model kunnen verder worden verbeterd door aanvullende gegevens te verzamelen en te toetsen:

- Grondwaterstanden: metingen van grondwaterstanden zijn gewenst om een gedetailleerder beeld te krijgen van de dynamiek in de grondwaterstanden.

- Oppervlaktewaterstanden in de sloten rond de percelen: mogelijk dat in verband met beregening dan wel droogtebestrijding de oppervlaktewaterpeilen (recent) gedurende droge perioden hoog opgezet worden.

- Drukhoogten gedurende een droge periode: wellicht dat remote-sensing gegevens hier extra informatie kunnen bieden (vanderSat beschikbaar vanaf 2002 in 100×100 m resolutie). 


\subsubsection{Gemodelleerde opbrengsten}

Figuur 3.11 geeft de transpiratie voor de verschillende jaren weer. Op veld 4 in 2018 en veld 6 in 2015 zijn zaaiuien geteeld, die volgens de simulatie een lage transpiratie hebben. Om een indruk te krijgen van de transpiratiereductie - dit is een maat voor de gewasgroeireductie - is in Figuur 3.12 de verhouding tussen de actuele en de potentiële transpiratie gegeven. Hieruit volgt dat vooral in 2018 en 2019 de transpiratiereductie groot was. Voor veld 6 is blok 14 NKG0 gevoeliger voor droogte dan blok 16 Ploeg25 (zie 2018 en 2019). Voor de gemiddelde jaren (2015 t/m 2017) zijn de verschillen verwaarloosbaar.

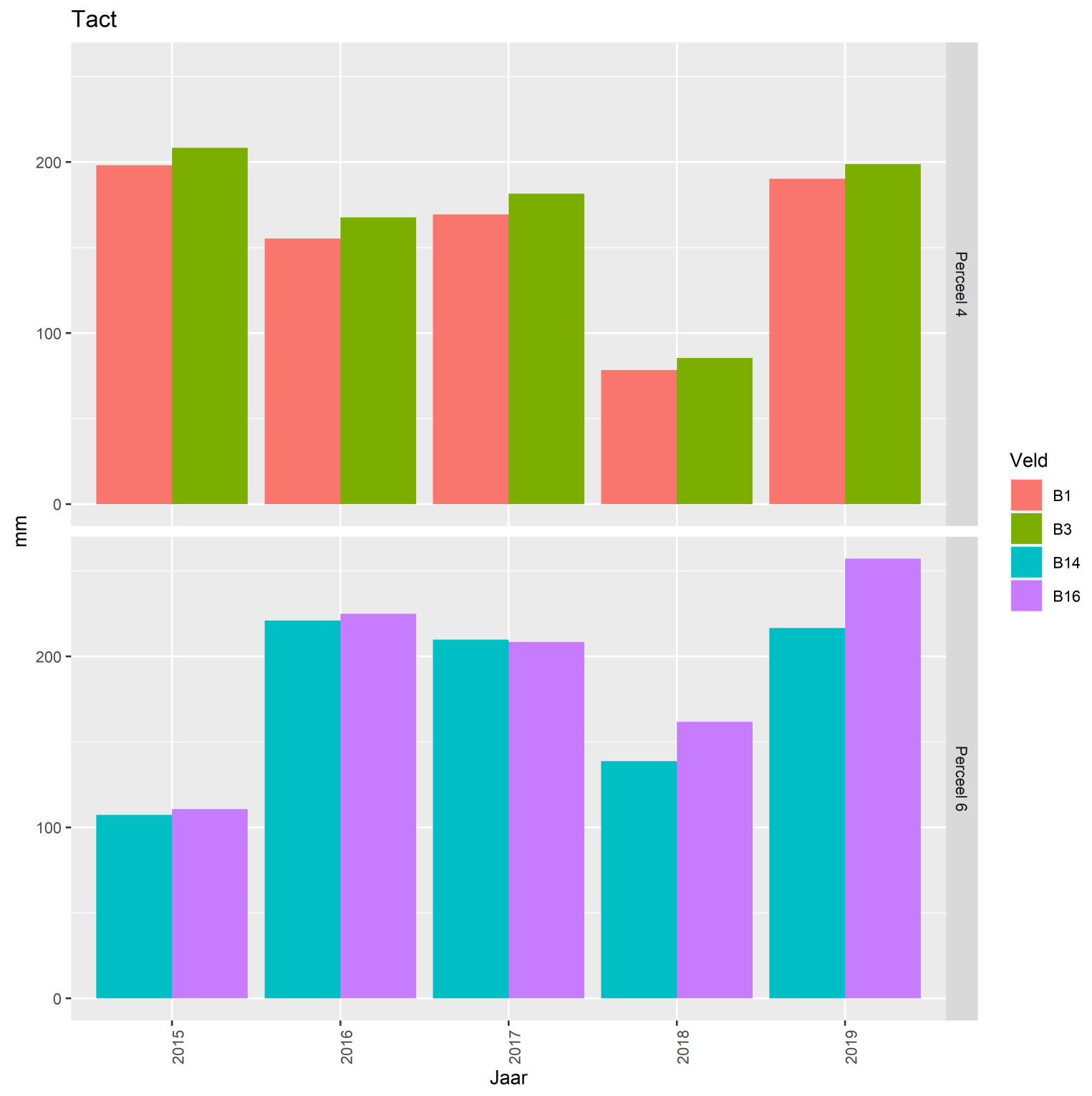

Figuur 3.11 Transpiratie voor de verschillende jaren Lelystad (Blok 1: Ploeg15, Blok 3: NKG20, Blok 14: NKG0, Blok 16: Ploeg25) als maat voor de groei van het gewas. 


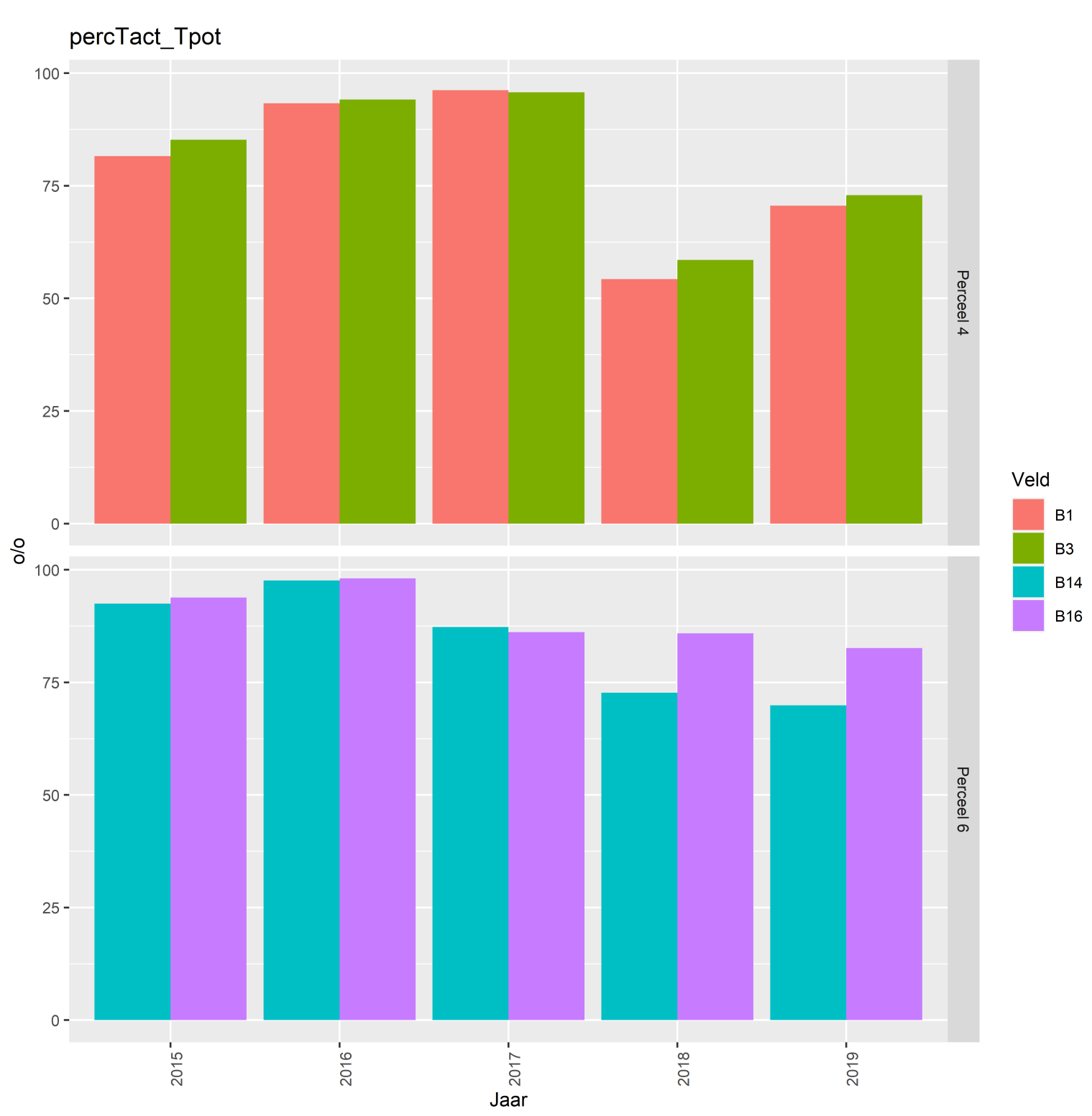

Figuur 3.12 Actuele transpiratie t.o.v. de potentiële transpiratie (in procenten) Lelystad als indicatie voor de groeireductie in \% van het gewas (Blok 1: Ploeg15, Blok 3: NKG20, Blok 14: NKG0, Blok 16: Ploeg25).

De modelresultaten van Figuur 3.12 en de gemeten opbrengstgegevens van Tabel 3.11 geven vergelijkbare resultaten, maar wijken met name in de droge jaren 2018 en 2019 van elkaar af. De modelresultaten simuleren dan een lagere opbrengst voor NKG0 ten opzichte van Ploeg25, terwijl de veldmetingen juist een hogere opbrengst laten zien. Een van de voordelen van gereduceerde grondbewerking kan een betere klimaatadaptatie zijn. Uit het model blijkt dit niet, maar uit de opbrengstgegevens van 2018 en 2019 wel. In 2020 was de opbrengst van NKG0 in enkele gevallen lager dan ploegen.

\subsection{Vredepeel SWAP: kalibratie en opbrengsten}

Voor de simulatie met SWAP is de beregening in 2020 toegevoegd aan de file met de neerslaggegevens. 


\subsubsection{Kalibratie en validatie}

De simulatie richt zich op het jaar 2020, omdat voor dit jaar de meeste meetgegevens voorhanden zijn. Tevens is een aantal voorafgaande jaren gemodelleerd om enerzijds de voorgeschiedenis van het jaar 2020 mee te nemen en anderzijds de effecten van verschillende weerjaren in beeld te krijgen. Bij de simulatie was in eerste instantie gekozen voor de daadwerkelijk geteelde gewassen, maar om ook de effecten van de weerjaren goed met elkaar te kunnen vergelijken, is ervoor gekozen ieder jaar zomergerst als gewas te kiezen met een groenbemester als nagewas. Getracht is een goede kalibratie te verkrijgen voor zowel de gemeten grondwaterstanden als de drukhoogten. Om de gemeten en berekende grondwaterstanden beter in overeenstemming te krijgen, is de drainagediepte enigszins dieper gekozen dan volgens de medewerker van Vredepeel was opgegeven: in de simulatie $110 \mathrm{~cm}$ -mv in plaats van $100 \mathrm{~cm}$-mv (volgens de medewerker van Vredepeel).

\subsubsection{Grondwaterstanden}

In Figuur 3.13 zijn de gesimuleerde en de gemeten grondwaterstanden weergegeven. Hieruit blijkt dat de grondwaterstanden voor de winterperioden redelijk tot goed gesimuleerd worden, maar voor de zomerperioden zoals in 2018 minder goed. In het jaar 2018 zakt de gemodelleerde grondwaterstand minder diep weg dan de gemeten grondwaterstand. Dit geldt ook voor een korte periode in 2019. Mogelijk is dit een gevolg van onttrekking van grondwater voor beregening in de buurt. Bekend is dat in de regio veel beregend wordt en dat dit invloed heeft op de grondwaterstanden. Deze beregening buiten het perceel is niet in het SWAP-model opgenomen. Een indicatie van het effect van de beregening buiten het perceel kan verkregen worden door gebruik te maken van de resultaten van een andere studie. In de droogtestudie van Van den Eertwegh et al. (2020) is met het LHM (Landelijk Hydrologisch Modelinstrumentarium) het effect van de beregening berekend: voor dit gebied is door beregening een verlaging van de grondwaterstand berekend van 10 tot $25 \mathrm{~cm}$ (voor het jaar 2018). Dit verklaart dus niet geheel het verschil van bijna $50 \mathrm{~cm}$ uit onderstaande figuren, maar de studie van Van den Eertwegh geeft wel aan dat het effect van lokale onttrekkingen voor beregening groot kan zijn.

Voor 2020 zien we dat in de zomer de grondwaterstanden juist hoger zijn. Bij de simulaties is voor 2020 uitgegaan van de DACOM-neerslaggegevens. Het station Volkel geeft voor 26 juni 2020 een neerslag van $86 \mathrm{~mm}$, terwijl dit in de DACOM-reeks $2 \mathrm{~mm}$ is. Het radarbeeld van die dag toont inderdaad dat boven Volkel veel regen is gevallen, maar niet in die mate boven het proefstation. De DACOM-gegevens lijken aan de lage kant. Onduidelijk is hoeveel neerslag daadwerkelijk is gevallen in de periode juli t/m september 2020. Voor meer informatie over de neerslaggegevens zie Bijlage 1 . 


\section{Stijghoogte 4003}

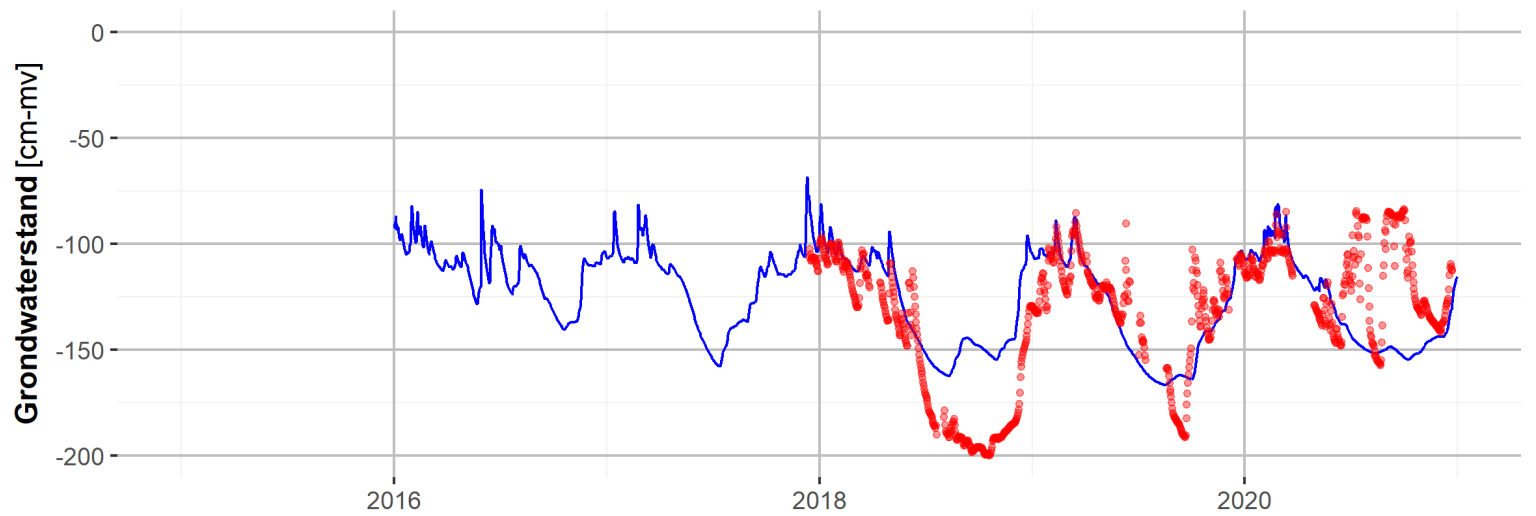

Stijghoogte 4803

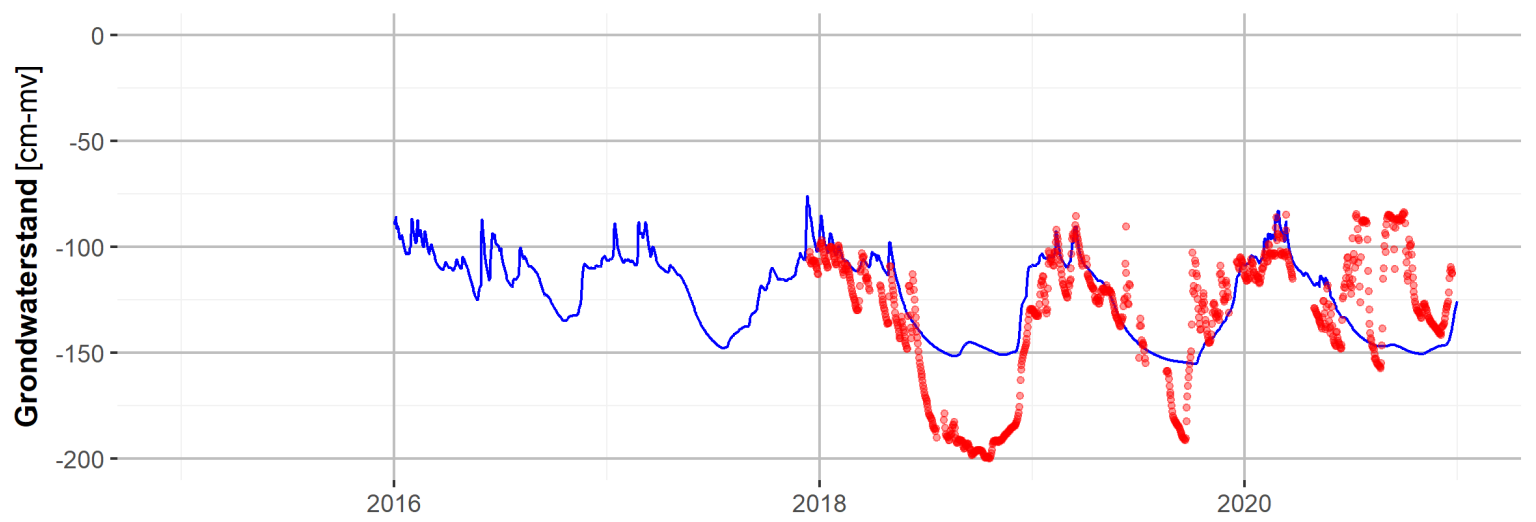

Figuur 3.13 Gesimuleerde (blauw) en gemeten (rood) grondwaterstanden voor plot 40 (NKG15, boven) en plot 48 (Ploeg30, onder).

\subsubsection{Drukhoogte}

Drukhoogten zijn gemeten in de periode van begin mei $\mathrm{t} / \mathrm{m}$ juli 2020. In Figuur 3.14 zijn de gesimuleerde en gemeten drukhoogten weergegeven. De gemeten drukhoogten op een diepte van $17 \mathrm{~cm}-\mathrm{mv}$ duiden op een drogere grond dan die van de berekende drukken. Ook op de diepten 41 en $46 \mathrm{~cm}-\mathrm{mv}$ zijn er verschillen, waarbij de metingen een sterkere fluctuatie in de drukhoogten laten zien dan de simulaties. 


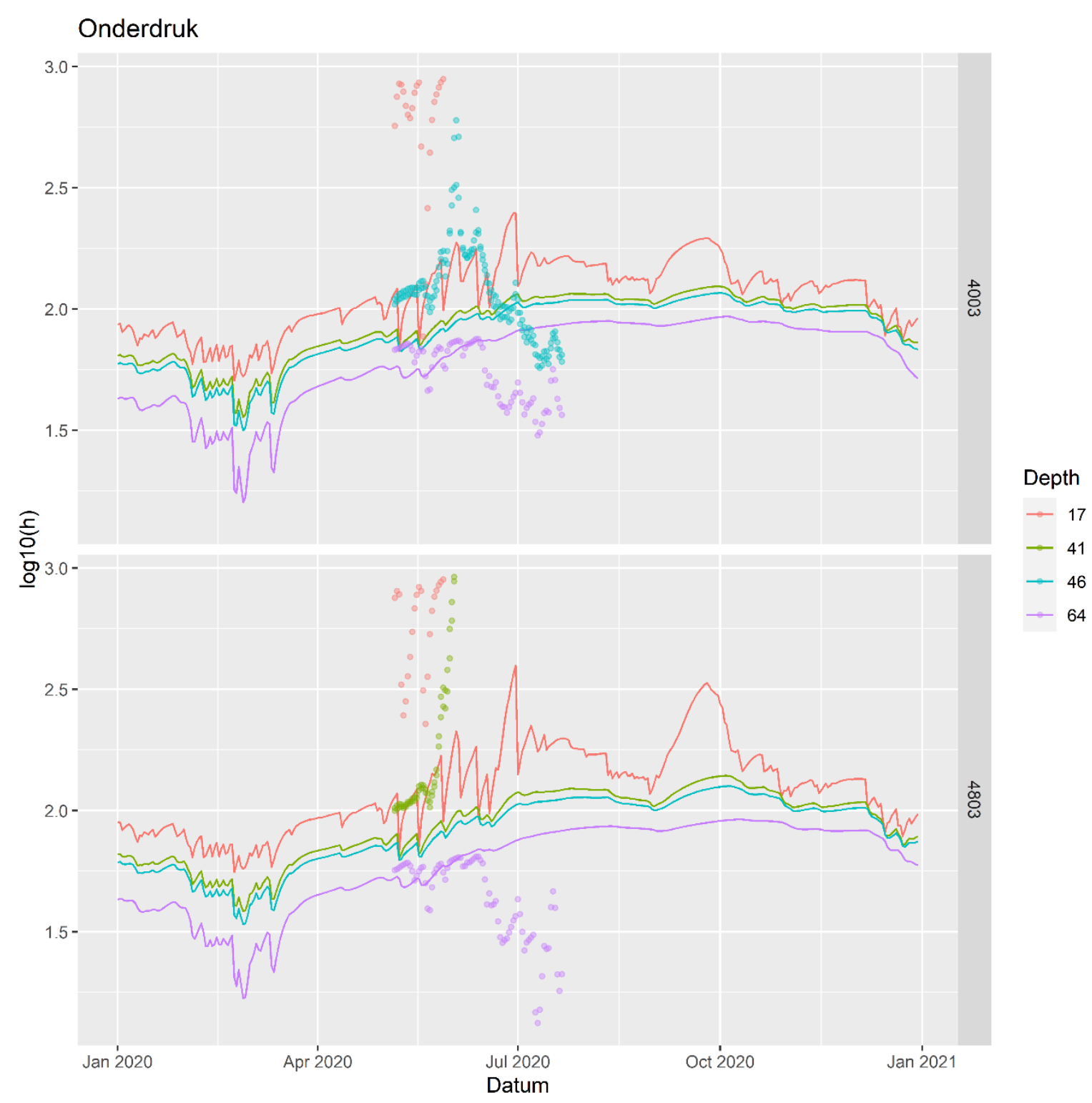

Figuur 3.14 Gesimuleerde (lijnen) en gemeten (punten) drukhoogten voor plot 40 (NKG15, boven) en plot 48 (Ploeg30, onder).

De drukhoogten in de diepere lagen hangen samen met de grondwaterstanden. De gemeten grondwaterstanden in het groeiseizoen van 2020 zijn gedurende langere tijd hoger dan de gesimuleerde grondwaterstanden (Figuur 3.15). De hogere gemeten grondwaterstanden vanaf half juni komen overeen met de daling van de pF-waarde (natter) van de tensiometer op $64 \mathrm{~cm}$ diepte. Mogelijk dat er een neerslagevent in de meetreeks ontbreekt in de periode van half juni tot half juli 2020 die daarom niet tot uiting komt in de drukhoogten zoals berekend door het model. 


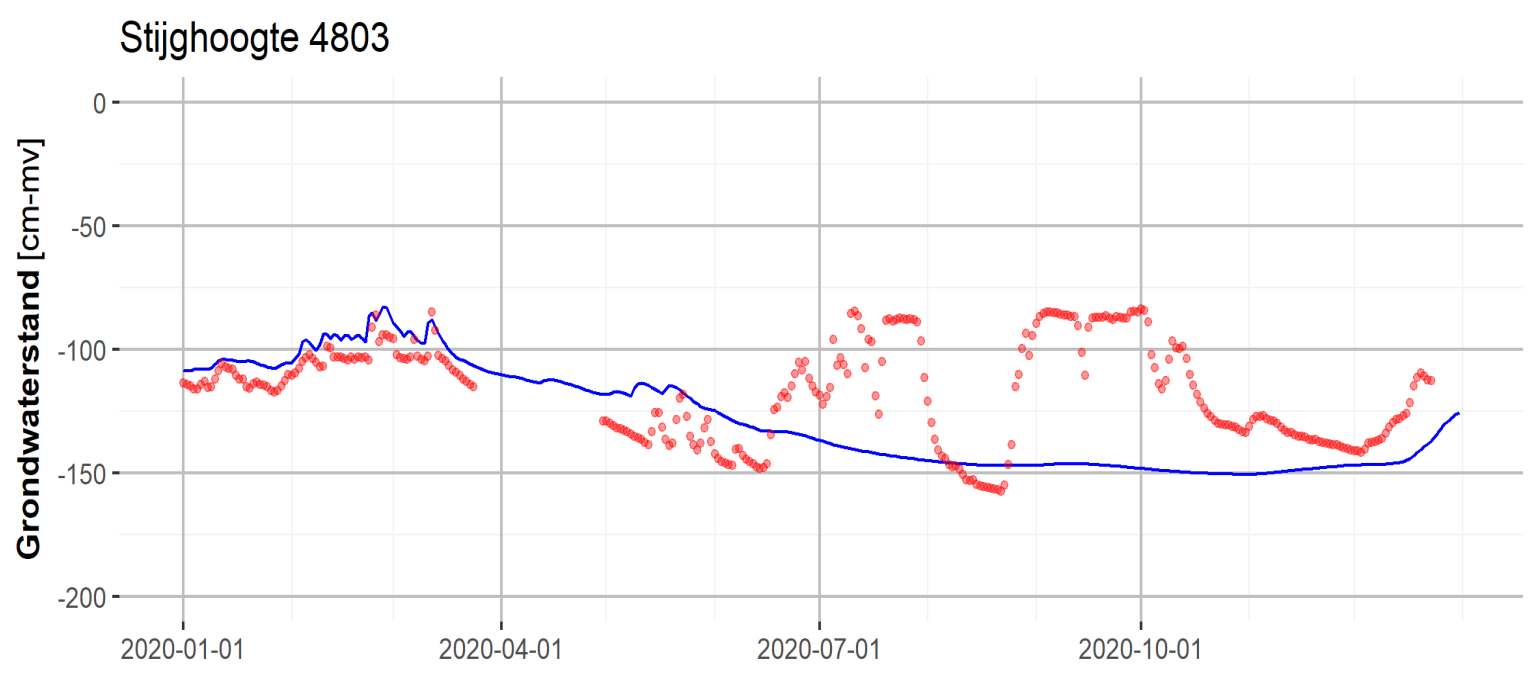

Figuur 3.15 Gesimuleerde (blauw) en gemeten (rood) grondwaterstanden op plot 48.

\subsubsection{Beoordeling modellering}

De simulatie van grondwaterstanden, drukhoogten en opbrengsten zijn vergelijkbaar, maar wijken op onderdelen of specifieke momenten van elkaar af. Aanvullende gegevens kunnen de simulatie verder verbeteren:

- De oppervlaktewaterstanden in de sloten rond de percelen: mogelijke afwijkingen tussen metingen en model kunnen optreden als in verband met droogtebestrijding de oppervlaktewaterpeilen gedurende droge perioden opgezet worden. Inzicht in deze gegevens vergroot de betrouwbaarheid van het model.

- Grondwateronttrekkingen t.b.v. beregening: wateronttrekkingen buiten de onderzoekspercelen beïnvloeden de grondwaterstanden op de onderzoekslocatie. Voor een goed vergelijk tussen de metingen en berekeningen van de grondwaterstand moet deze invloed meegenomen worden.

- Neerslaggegevens: de verschillende databronnen voor de neerslag geven geen eenduidig beeld voor 2020. Een accuraat beeld van neerslaghoeveelheden is nodig.

- Drukhoogte: de drukhoogtemetingen zijn betrouwbaar, zolang de drukhoogte niet kleiner wordt dan $-900 \mathrm{~cm}$. Een drukhoogte < $-900 \mathrm{~cm}$ wordt bereikt als het erg droog wordt. Dit gebeurt meestal het eerst in de bouwvoor door evapotranspiratie. De watergevulde tensiometers slaan dan door en stoppen met werken. Het is wenselijk de tensiometerreeksen uit te breiden om meer fundament voor modelkalibratie te krijgen. Hervullen van de tensiometers na een droge periode is hiervoor een goede oplossing of door gebruik te maken van polymeertensiometers. Deze zijn duurder in aanschaf, maar besparen veel tijd en geld doordat ze nagenoeg onderhoudsvrij zijn.

\subsubsection{Gemodelleerde opbrengsten}

In Tabel 3.21 zijn de gemeten en berekende opbrengsten voor 2020 weergegeven. Het stuifzandincident op plot 40 is niet meegenomen in de simulaties, waardoor de gesimuleerde opbrengsten daar hoger zijn dan de gemeten opbrengsten.

Tabel 3.21 Gewas 2020.

\begin{tabular}{lll} 
Systeem & NKG15 & Ploeg30 \\
Perceel & $27.1 \mathrm{a}$ plot 40 & $27.1 \mathrm{~b}$ plot 48 \\
\hline Gewas & Zomergerst & Zomergerst \\
\hline $\begin{array}{l}\text { Veldmeting: } \\
\text { Gecorrigeerde korrelopbrengst naar 15\% vocht (kg/ha) }\end{array}$ & 6.014 & 8.177 \\
\hline $\begin{array}{l}\text { SWAP-simulatie: } \\
\text { Korrelopbrengst (CWSO) }\end{array}$ & 6.929 & 7.177 \\
\hline
\end{tabular}




\section{Discussie}

\subsection{Beoordeling hydrofysische kenmerken}

In deze paragraaf vindt een directe beoordeling plaats van de gemeten hydrofysische bodemparameters. Deze parameters zijn voor een groot deel gebruikt in de SWAP-modelinvoer. Tezamen met andere parameters wordt in de paragrafen die gaan over de SWAP-modellering vooral gekeken naar gewasopbrengst, ofwel in model-termen, naar de actuele verdamping ten opzichte van de potentiële verdamping.

\subsubsection{Lelystad}

Tabel 4.1 geeft een samenvatting van de kwaliteit van de hydrofysische kenmerken zoals weergegeven in Tabel 3.7.

Tabel 4.1 Samenvatting van de kwaliteit van de hydrofysische kenmerken Lelystad. Als de waarde voldoet aan de eisen, krijgt deze de waardering 'goed'. Als de waarde niet voldoet, wordt deze weergegeven met tussen haakjes het diepte-interval waarop de waarde geldig is. Eisen: Poriënvolume moet $>40 \%$; Droge bulkdichtheid moet < $1.6 \mathrm{~g} / \mathrm{cm3}$, of bij klei\%>16.5\%: < $1.75-0.009 * \mathrm{C}$; Ksat ( = verzadigde waterdoorlatendheid) moet $>10 \mathrm{~cm} / \mathrm{d}$; Luchtgehalte moet $>10 \%$ bij drukhoogte $=$ $-50 \mathrm{~cm}$; Indringweerstand moet $<3 \mathrm{MPa}$.

\begin{tabular}{lllll} 
Eenheid & NKG0 & NKG20 & Ploeg15 & Ploeg25 \\
& Blok 14 & Blok 3 & Blok 1 & Blok 16 \\
Poriënvolume\% & $37(20-30)$ & $39(25-35)$ & $35(25-35)$ & Goed \\
\hline Dichtheid g/cm ${ }^{3}$ & $1.6(20-30)$ & Goed & $1.7(25-35)$ & Goed \\
\hline Ksat cm/d & Goed & Goed & Goed & Goed \\
\hline Luchtgehalte\% & $4(20-30)$ & $6(25-35)$ & $<1(25-35)$ & $9(25-35)$ \\
bij $h=-50$ & $3(50-60)$ & $2(55-65)$ & & $4(60-70)$ \\
\hline $\begin{array}{l}\text { Indr.weerstand 2019 } \\
\text { Idem 2009-2016 }\end{array}$ & $3-5(>65)$ & $3-4(>70)$ & $3.2(30-35)$ & Goed \\
\hline
\end{tabular}

Uit Tabel 3.7 en Tabel 4.1 blijkt dat de verzadigde waterdoorlatendheid $\left(K s a t>=26 \mathrm{~cm} . \mathrm{d}^{-1}\right.$ ) altijd ruim groter is dan de drempelwaarde van $10 \mathrm{~cm} . \mathrm{d}^{-1}$. Er zijn daarmee geen problemen te verwachten ten aanzien van de waterafvoer bij hevige regenbuien.

De drempelwaarde van de droge bulkdichtheid wordt overschreden bij

- Blok 1, Bed1 Ploeg15

- Blok 14, Bed 66 NKG0

Bij 'Blok 16, Bed 76 Ploeg25' blijkt de mediaan van de droge bulkdichtheid van de ploegzool net overeen te komen met de toegestane grenswaarde en wordt daarmee als 'goed' beoordeeld.

Het volume poriën (moet $>$ 40\%) en het volume lucht bij vochtspanningen van -50 (moet $>10 \%$ ) en $\mathbf{- 1 0 0} \mathbf{~ c m}$ waterdruk van alle ploegzolen zijn kleiner dan de toegestane minimale waarden. Daarvan heeft de ploegzool van 'Blok 16, Bed 76 Ploegen25' de minst slechte kwaliteit. De diepere ondergrond op circa $60 \mathrm{~cm}$ diepte blijkt ondanks de lage droge dichtheden in alle gevallen te lage tot veel te lage luchtgehalten te hebben bij vochtspanningen van -50 en $-100 \mathrm{~cm}$ waterdruk. Hieruit blijkt dat deze ondergrond zeer slecht gestructureerd is. Dit blijkt ook uit de gemeten verzadigde doorlatendheden die ondanks de lage dichtheden veel lager zijn dan de Ksat van de veel dichtere ploegzool. 
In Figuur 4.1 zijn de mediane indringweerstanden op 24 april 2019 gepresenteerd. De indringweerstanden zijn toen in tienvoud gemeten op dezelfde dag dat de bodemfysische bemonstering plaatsvond.

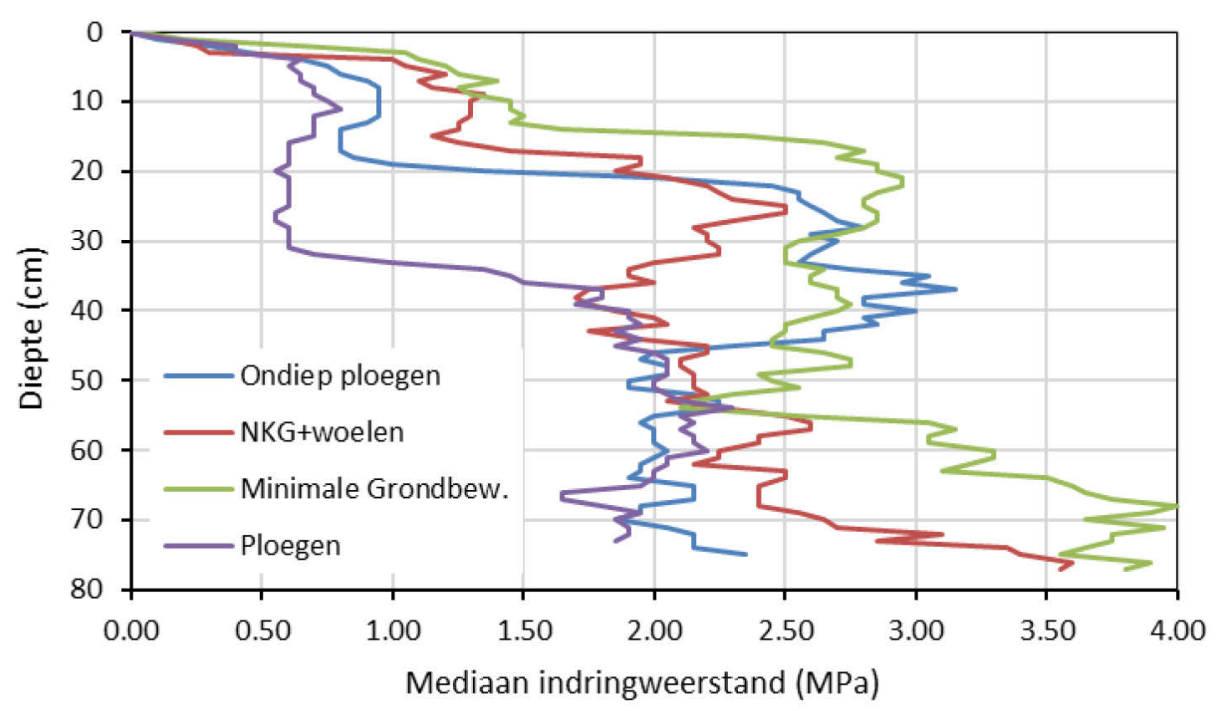

Figuur 4.1 Indringweerstanden in het voorjaar van 2019 (24 april 2019). Minimale Grondbewerking komt overeen met NKG. Mediaanwaarden van 10 metingen per plot.

Het blijkt dat tot ca. $55 \mathrm{~cm}$-mv alleen 'Blok 1, Bed 1 Ploeg15' de drempelwaarde van $3 \mathrm{MPa}$ overschrijdt op een diepte van ca. $35 \mathrm{~cm}$. Verrassend is dat tot een diepte van ca. $30 \mathrm{~cm}$, dus nog ca. $5 \mathrm{~cm}$ onder de ploegdiepte, de indringweerstand van 'Blok 16, Bed 76 Ploeg25' veel lager is dan bij de andere behandelingen.

Figuur 4.2 geeft van veld 6 de mediane indringweerstand over de periode 2009-2016 voor ploegen en NKG. Hierbij zitten ook 'Blok14, B66 NKG0' en 'Blok16, B76 Ploeg25'. Ook hier blijkt dat voor ploegen, net als in Figuur 4.1, de bovengrond tot een diepte van 25 tot $30 \mathrm{~cm}$ een lagere indringweerstand heeft dan bij de blokken met NKG. De blokken met NKG blijken een ploegzool te hebben van ca. 25 tot ca. $40 \mathrm{~cm}$ diepte, waar de indringweerstand terugvalt naar lagere waarden en dieper weer oploopt.

De indringweerstanden lijken bij de blokken met ploegen in het algemeen iets lager te zijn dan bij de blokken met NKG, maar alleen bij de bovengrond is dat echt duidelijk.

Opvallend in Figuur 4.2 is dat dieper dan circa $30 \mathrm{~cm}-\mathrm{mv}$ voor 'Ploegen 16 ' de laagste indringweerstanden heeft van de vier blokken met ploegen. Bij NKG heeft blok 14 juist de hoogste indringweerstanden van alle blokken met NKG. Dat maakt de vergelijking in Figuur 4.2 tussen 'Blok14, B66 NKG0' en 'Blok16, B76 Ploeg25' wel problematischer, temeer omdat dit misschien ook geldt voor de andere bodemfysische eigenschappen van 'Blok14, B66 NKG0' en 'Blok16, B76 Ploeg25'.

Geconcludeerd wordt dat de bodemkwaliteit bij de verschillende behandelingen niet wezenlijk verschilt. Wat betreft de ondergrond (onder de ploegdiepte) lijkt ploegen, maar ook NKG20 eerder een klein voordeel dan een nadeel op te leveren. De ondergrond is gevoelig voor verdichting in de laag direct onder de bouwvoor en wordt ook daadwerkelijk te dicht. Opvallend is dat de diepere ondergrond een vrij lage dichtheid heeft, maar wel relatief hoge indringweerstanden. Misschien dat schelpenbanden voor deze hoge indringweerstanden zorgen. De diepere ondergrond heeft relatief lage verzadigde doorlatendheden en zeer lage luchtgehalten. Dit duidt op een slecht gestructureerde grond. Omdat er in de diepere lagen minder zwel en krimp is, de vorst moeilijker doordringt en het bodemleven minder actief is, verloopt structuurvorming van deze lichte zavel traag. Als deze laag door vochtonttrekking door wortels droger wordt, zal beworteling goed mogelijk zijn vanwege de lage dichtheid (indringweerstand niet meegerekend). Omdat dit profiel bovendien enkele mm's kwel heeft, 
zal een wat dieper wortelend gewas niet snel droogtestress ondervinden. Het probleem daarbij is dat de verdichte laag op ca. $30 \mathrm{~cm}$ diepte juist die diepere beworteling kan verhinderen of beperken.

De ontwikkeling in de tijd is alleen gemeten voor de indringweerstand (Figuur 3.3). De indringweerstanden geven geen duidelijke trend te zien. Alle andere parameters zijn op slechts één moment (2019) gemeten. Er is dus geen goed tijdsverloop aan te geven. Een uitgebreider onderzoek kan hier uiteraard wel antwoord op geven.
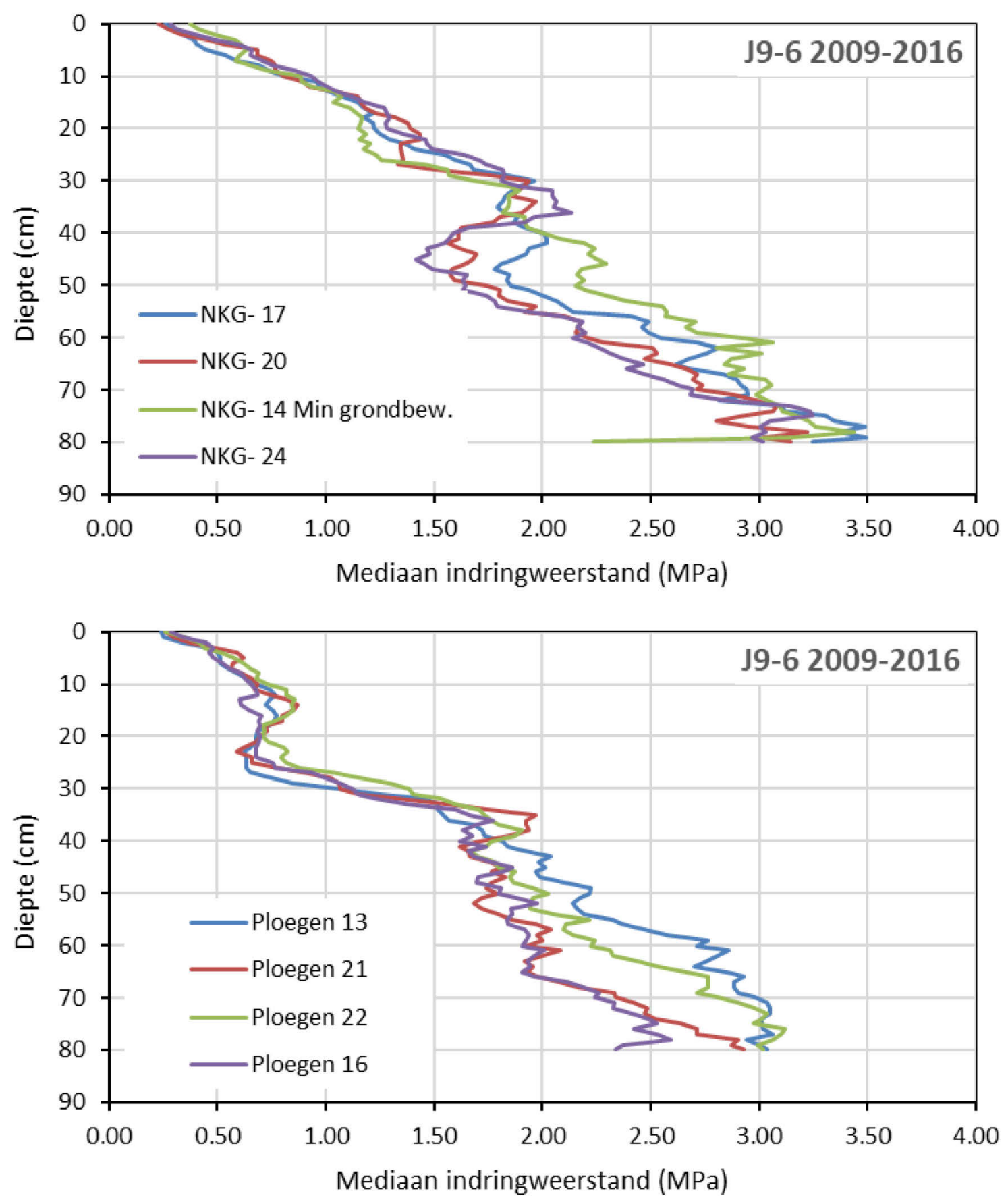

Figuur 4.2 Mediane indringweerstanden in de periode 2009-2016 van veld 6 van de blokken met in de bovenste figuur de behandeling NKGO (NKG-14 Min grondbew.) en in de onderste figuur de behandeling Ploeg25 (Ploegen 16). 


\subsubsection{Vredepeel}

Tabel 4.2 geeft een samenvatting van de kwaliteit van de hydrofysische kenmerken zoals weergegeven in Tabel 3.15.

Tabel 4.2 Samenvatting van de kwaliteit van de hydrofysische kenmerken Vredepeel. Als de waarde voldoet aan de eisen krijgt deze de waardering 'goed'. Als de waarde niet voldoet, wordt deze weergegeven met tussen haakjes het diepte-interval waarop de waarde geldig is. Eisen: Porievolume moet > 40\%; Droge bulkdichtheid moet < $1.6 \mathrm{~g} / \mathrm{cm3}$, of bij klei\%>16.5\%: < $1.75-0.009 * \mathrm{C} ; \mathrm{Ksat}$ (= verzadigde waterdoorlatendheid) moet $>10 \mathrm{~cm} / \mathrm{d}$; Luchtgehalte moet $>10 \%$ bij drukhoogte $=$ $-50 \mathrm{~cm}$; Indringweerstand moet $<3 \mathrm{MPa}$.

\begin{tabular}{lll} 
Eenheid & NKG15 & Ploeg30 \\
& Plot 40 & Plot 48 \\
Poriënvolume\% & $35(65-75)$ & $35(65-75)$ \\
\hline Dichtheid g/cm3 & $1.7(65-75)$ & $1.7(65-75)$ \\
\hline Ksat cm/d & Goed & Goed \\
\hline Luchtgehalte\% bij $h=-50$ & Goed & Goed \\
\hline Indringweerstand 2020 & $3-5(39-60)$ & $3-5.5(48-57)$ \\
\hline
\end{tabular}

Uit de tabel blijkt dat beide percelen vergelijkbaar presteren. De verzadigde waterdoorlatendheid en het volume lucht voldoen aan de eisen. Het volume poriën (moet $>40 \%$ ), de droge bulkdicht en de indringweerstand voldoen echter niet. Als in zandgronden een stelsel van voldoende grote poriën aanwezig is, verschuift de kritische grens voor de indringweerstand naar 3-5 MPa. De gevonden waarden voldoen daarmee ook aan de gestelde eis en vormen geen probleem voor de bewortelbaarheid. Uit het bewortelingsonderzoek (zie tabellen 3-19 en 3-20) blijkt echter duidelijk dat bij Plot 40 (NKG15) de overgrote meerderheid van de wortels niet dieper komt dan $30 \mathrm{~cm}$ en bij Plot 48 (Ploeg30) niet dieper dan $40 \mathrm{~cm}$.

\subsection{Opbrengsten ploegen versus NKG}

\subsubsection{Lelystad}

Uit de veldgegevens blijkt dat in 2009-2015, dus in de eerste jaren van het onderzoek, de gewasopbrengsten van het NKG-systeem over het algemeen circa 5\% lager waren dan die van het reguliere grondbewerkingssysteem ploegen. In de jaren 2015-2017 nam dat verschil af en in de jaren 2018-2020 zijn gewasopbrengsten van het NKG-systeem juist groter (8\%) dan die van het reguliere systeem ploegen.

Uit de modelsimulaties blijkt dat voor de gemiddelde jaren 2015 t/m 2017 de verschillen tussen NKG0 (blok 14) en Ploeg25 (blok 16) verwaarloosbare verschillen in opbrengst geven. In de jaren 2018-2019 blijft de groei van NKG achter bij die van ploegen.

Waarschijnlijk is de lagere gesimuleerde opbrengst in de droge jaren bij NKG veroorzaakt door de geringere bewortelingsdiepte in het model bij blok 14 in vergelijking met die bij blok 16 . Omdat de in het veld fysiek gemeten worteldiepten op de betreffende percelen niet bekend waren ten tijde van het onderzoek, zijn deze als invoer van het model bepaald op basis van de indringweerstand en de potentiële worteldiepte van het gewas (in ongelimiteerde omstandigheden). Door de verschillen in opbrengst tussen de veldgegevens en de gewasverdampingsreducties van het model, kan maar beperkt waarde worden gehecht aan de resultaten van de droge jaren. Het blijkt dat zowel in de praktijk als in de modellering in normale weerjaren NKG en ploegen geen noemenswaardige opbrengstverschillen geven. Dat is in lijn met de verwachtingen. Als het gewas voldoende vocht krijgt in de wortelzone (normale weerjaren) en andere groeicondities niet zijn geremd, zijn er geen verschillen in de verschillende behandelingen te verwachten. De verschillen zijn wel te verwachten in droge en natte jaren, als er onvoldoende vochttransport tussen de wortelzone en de ondergrond op 
kan treden. Het model gaat uit van ondiepe wortels bij NKG0 op basis van de gemeten indringweerstanden en berekent daarom een lagere opbrengst bij NKG dan bij ploegen in de droge jaren. Dit is in lijn met de hydrofysische beoordeling in Tabel 3.7. Daarbij moet worden opgemerkt dat niet alle bodemlagen bemonsterd konden worden en alleen zijn beoordeeld in april 2019. De veldmetingen geven juist een hogere opbrengst in de droge jaren. De veldgegevens kunnen echter geen sluitende relatie leggen tussen de bodemgesteldheid en de opbrengst. De huidige set meetgegevens is onvoldoende om een verklaring te geven voor de gevonden opbrengstverschillen. Eventuele hydrofysische verschillen van de bodemlagen zullen vooral in droge (en natte) jaren resulteren in een verschil in opbrengst tussen NKG en ploegen en dan met name na een jaar of zeven na de initiële grondbewerking van diep woelen, waarin de verschillen tussen NKG en ploegen tot uiting kunnen komen.

\subsubsection{Vredepeel}

De opbrengsten zijn weergegeven in Bijlage 12. Op de percelen met zowel NKG als Ploegen is de spreiding in de veldmeetgegevens van de opbrengsten groot. Een duidelijk effect van de grondbewerking is met deze veldgegevens daarom niet aan te geven. In de simulaties zijn de opbrengstverschillen beperkt (ca. 3,5\%). Ook daarmee is geen duidelijk effect van de grondbewerking/management aan te geven. Uit de SWAP-simulaties blijkt de invloed van grondwateronttrekking door beregeningen en peilbeheer oppervlaktewater mede belangrijk voor de vochtbeschikbaarheid van een gewas door het effect ervan op het niveau van het grondwater. Beregeningen spelen overigens een rol in het uitblijven van een duidelijk waarneembaar verschil tussen de verschillende behandelingen, omdat verschillen pas waarneembaar worden in extreme omstandigheden zoals droogte of overmatige regen, waarin een verdichte ondergrond (bij ploegen) stagnerend kan werken in het transport van vocht tussen de ondergrond en de wortelzone. Een beregening zorgt ervoor dat dit effect niet waarneembaar is op de gewasgroei: het gewas krijgt dan altijd voldoende vocht, ongeacht de eigenschappen van de bodem.

De opbrengstverschillen tussen NKG15 en Ploeg30 zijn in het meetjaar 2020 voor ondergrondverdichting voornamelijk het gevolg van een stuifzandincident in het vroege voorjaar. De veldmetingen kunnen in dat jaar dus niet goed vergeleken worden met die van de modelresultaten.

\subsection{Effect en duur langjarig natuurlijk herstel}

Voor zowel Lelystad als Vredepeel lijkt er geen positief effect te zijn van NKG op het voorkomen van een ploegzool of van diepere ondergrondverdichting. Integendeel, zowel in Lelystad als in Vredepeel blijken de fysische bodemkwaliteiten van de laag onder de bewerkingsdiepte bij ploegen beter dan bij de NKG-behandeling. In Vredepeel blijkt dit ook uit een $10 \mathrm{~cm}$ diepere bewortelingsdiepte. Hier is de bewortelingsdiepte $40 \mathrm{~cm}$ bij ploegen en $30 \mathrm{~cm}$ bij NKG.

In Lelystad zijn naast normaal ploegen (Ploeg25) en geen grondbewerking (NKG0) ook de behandelingen NKG+cultiveren tot maximaal $20 \mathrm{~cm}$ (NKG20) en ondiep ploegen tot $15 \mathrm{~cm}$ (Ploeg15) beschouwd op hun bodemfysische kwaliteit. Het lijkt erop dat NKG20 een betere ondergrond oplevert dan NKG0, min of meer te vergelijken met die van Ploeg25. Ploeg15 lijkt juist wat betreft de ondergrond geen verbetering van de fysische kwaliteit op te leveren ten opzichte van Ploeg25: het geeft zelfs een slechtere ondergrond. Opgemerkt moet worden dat dit object tot nu toe slechts één keer ondiep geploegd is en voorheen NKG0 was. Wellicht heeft dat invloed op het resultaat.

Een belangrijk aandachtspunt is dat er per behandeling maar in één plot is bemonsterd. Statistisch gezien zijn de metingen dus veel te beperkt om significante verschillen te laten zien. In verband met de kosten zijn uitgebreide metingen van hydrofysische kwaliteiten niet uitgevoerd. Een tussenoplossing kan zijn door bijvoorbeeld op een groot aantal plots de indringweerstanden, dichtheden en luchtgehalten bij $-50 \mathrm{~cm}$ waterdruk te meten en bij relevante gewassen op het einde van het groeiseizoen de bewortelingsdiepten vast te stellen, waardoor wellicht wel significante verschillen aangetoond kunnen worden. Beter is uiteraard om een uitgebreide meetserie op te zetten, waarin de (hydro)fysische toestand van bodem en gewas nauwlettend wordt gemonitord over een 
langere tijd ( $>7$ jaar). Dit is wellicht kostbaar, maar geeft wel een sluitend beeld voor zowel de verschillen tussen de behandelingen alsook de trend in de tijd. Uit voorliggend onderzoek lijkt naar voren te komen dat ploegen in het begin van de proeftijd grotere opbrengsten geeft dan NKG en dat dit voordeel na verloop van circa zeven jaar is verdwenen. De spreiding in de resultaten en de onzekerheid in de variabelen zijn echter groot. Dit rapport geeft voor dat vermoeden daarom geen sluitend bewijs.

\title{
4.4 Effect groenbemesters
}

\subsubsection{Lelystad}

In Lelystad zijn tijdens de proef wel groenbemesters geteeld, maar het effect ervan is niet onderzocht.

\subsubsection{Vredepeel}

In 2020 is op de proefvelden Zomergerst geteeld met Japanse Haver als groenbemester. Conclusies over de effecten van de groenbemester zijn niet te trekken, omdat er geen referentieperceel zonder groenbemester is geweest tijdens de proef.

\subsection{Uitvoerbaarheid maatregelen}

\author{
Door Ing. D.J.M. van Balen
}

De uitvoerbaarheid van maatregelen maakt geen integraal onderdeel uit van voorliggend onderzoek. Hieronder volgt wel een korte toelichting met een verwijzing naar relevante literatuur.

\subsubsection{Lelystad}

Het systeem van gereduceerde grondbewerking zoals deze in Lelystad op de proef van BASIS is toegepast, gaat uit van de principes van 'Conservation Agriculture'. Naast het beperken van de grondbewerking en uitgekiende vruchtwisseling wordt ervoor gekozen de grond zo lang mogelijk bedekt te houden. Hiermee wordt verbetering van de bodemkwaliteit nagestreefd. Voor het telen van met name fijnzadige gewassen (zaaiuien, peen, suikerbieten) is het lang bedekt houden een probleem dat kan resulteren in een lager plantaantal, wat vervolgens leidt tot een lagere opbrengst. Door te kiezen voor een langere periode van onbedekte grond voor deze gewassen kunnen problemen met het creëren van een goed zaaibed voorkomen worden. Consequentie kan zijn dat het bodemvormend proces door gewas en bodemleven langer duurt.

(Literatuur: Van Balen et al., 2020; Van Balen \& Haagsma 1, 2015; Van Balen \& Haagsma 1, 2015; Norén et al., 2021)

\subsubsection{Vredepeel}

Op zandgrond ligt het accent van de hoofdgrondbewerking van zowel ploegen als gereduceerde grondbewerking in het voorjaar. Dit verkort de bodembedekkingsperiode in gereduceerde grondbewerking. Op zandgrond is er, in tegenstelling tot klei- en zavelgrond, geen sprake van herstellend vermogen van de structuur van de grond door zwel en krimp. Daarom wordt de bodem in het voorjaar op zandgrond over het algemeen dieper bewerkt dan op kleigrond.

(Literatuur: Van Balen et al., 2020; Norén et al., 2021) 


\subsection{Kosten en baten maatregelen}

Door Ing. D.J.M. van Balen

Ook een kosten-batenafweging is geen onderdeel geweest van voorliggend onderzoek. Hieronder volgt wel een korte toelichting met een verwijzing naar relevante literatuur.

\subsubsection{Lelystad}

Een systeem van gereduceerde grondbewerking op zavel of kleigrond geeft minder kosten dan een systeem met de conventionele grondbewerking ploegen.

Biologische rotatie: De kosten zijn circa $€ 60 /$ ha lager voor een biologische rotatie. De opbrengsten zijn daarentegen lager in vooral de biologische rotatie met peen, waardoor het netto resultaat lager is: $€ 500 /$ ha voor NKG20 en $€ 650 /$ ha voor het NKG0-systeem ten opzichte van ploegen. Door aanpassingen in teelt- en zaaitechniek is het volgens Wolf et al. (2019) mogelijk om opbrengstverschillen te verkleinen.

Gangbare rotatie: Voor de gangbare rotatie zijn de verschillen aanmerkelijk kleiner dan voor biologische rotatie. De kosten voor NKG zijn ook hier lager dan voor ploegen: $€$ 15/ha voor NKG20 en $€ 60$ /ha voor NKG0. De opbrengsten zijn gelijk of $€ 80 /$ ha lager dan bij ploegen. Het resultaat ten opzichte van ploegen is circa $€ 10$ /ha hoger voor NKG20 en $€ 60$ /ha lager voor NKG0.

\subsubsection{Vredepeel}

De verschillen tussen ploegen en gereduceerde grondbewerking zijn:

Biologische rotatie: NKG levert circa $€ 162$ /ha minder op dan ploegen.

Gangbare rotatie: NKG levert circa $€ 50 /$ ha minder op dan ploegen.

(Literatuur: Wolf et al., 2019) 


\section{Conclusie en aanbevelingen}

\section{$5.1 \quad$ Conclusies}

De hypothese in voorliggend onderzoek is dat de ondergrondverdichting verminderd kan worden door het gelijktijdig toepassen van twee maatregelen:

1. Gebruik een bodemmanagementsysteem (mechanische bewerking) dat verdichting voorkomt én

2. Laat de bodem zich door de jaren heen op natuurlijke wijze herstellen.

Ad1: Er zijn in dit onderzoek geen duidelijke aanwijzingen dat ondergrondverdichting door NKG in vergelijking met ploegen is verminderd.

Ad 2: In de loop van de tijd zijn in de wortelzone en/of ondergrond veranderingen zijn opgetreden, hetgeen blijkt uit de toename van de opbrengsten bij NKG in de tijd. Mogelijke verklarende veranderingen zijn bodemleven, netwerk van macroporiën en beschikbaarheid van nutriënten.

Toelichting:

- De fysische kwaliteit van de ondergrond direct onder de bewerkingsdiepte is bij NKG op een aantal punten duidelijk slechter dan bij ploegen. Dit geldt voor zowel de locatie Lelystad (zavelgrond) als de locatie Vredepeel (zandgrond). Dit is een resultaat dat niet voor de hand ligt, maar wel is te verklaren.

- De modelsimulatie met SWAP geeft bij ploegen voor beide locaties in beperkte mate een iets hogere, maar niet significant grotere opbrengst in droge jaren dan bij NKG. Deze simulatie is uitgevoerd met de gemeten hydrofysische parameters als invoer en gegevens omtrent bewortelingsdiepte en/of bewortelbaarheid.

- De gemeten opbrengsten laten zien dat de opbrengsten van NKG weliswaar in de jaren toeneemt, maar dat het pas na een jaar of zeven vergelijkbare opbrengsten geeft als ploegen.

- De spreiding in de resultaten en de onzekerheid in de variabelen zijn vanwege de beperkte omvang van het onderzoek aanzienlijk. De hypothese kan daarom niet aangenomen, maar ook niet verworpen worden: het onderzoek geeft onvoldoende significant bewijs voor het effect van de maatregelen.

Ondanks dat het geen deel uitmaakt van voorliggend onderzoek, wordt met hulp van verwant onderzoek getracht een voorlopig antwoord te geven op de volgende drie vragen:

1. Hoe eenvoudig zijn de maatregelen uit te voeren?

De maatregelen zijn eenvoudig uit te voeren. Een beschouwing over teelttechnische en economische aspecten zijn in werkpakket 5 onderzocht en beschreven.

2. Wat zijn de kosten/baten van de verschillende bewerkingen?

Er zijn minder kosten te verwachten door ondieper ploegen. Deze grondbewerking is echter nog niet in een economische analyse meegenomen. In een systeem van gereduceerde grondbewerking worden verhoogde kosten verwacht door toename van onkruiddruk, maar de netto kosten voor grondbewerking (brandstof, arbeid, machinekosten) zijn daar lager. Het onderzoek naar de kosten en baten is verricht in werkpakket 5: de opbrengstverschillen voor de verschillende bewerkingen en rotaties zijn op klei/zavelgrond groter dan op zandgrond. Het verschil tussen gangbare rotatie en biologische rotatie is groter door opbrengstverschillen van hoog salderende gewassen. De opbrengsten bij een biologische rotatie zijn aanmerkelijk lager voor NKG ten opzichte van ploegen.

3. Na hoeveel jaar kunnen effecten verwacht worden?

Het duurde in dit onderzoek circa zeven jaar voordat de opbrengsten van een NKG (in combinatie met een biologisch teeltsysteem) vergelijkbaar waren met die van de traditionele grondbewerking ploegen. Positieve effecten van NKG op het voorkomen en/of herstellen van ondergrondverdichting zijn niet geconstateerd. Er zijn zelfs aanwijzingen dat ploegen daarin betere resultaten laat zien. 


\subsection{Aanbevelingen}

Een onderzoek en proef zoals die in voorliggend rapport zijn beschreven, zijn complex en kunnen vele variabelen bevatten die van invloed zijn op de resultaten. Een beperkt onderzoek zoals dit laat zien dat het geen harde wet is die pleit voor NKG of regulier ploegen. Het toont aan dat ploegen met een wiel in de bouwvoor niet automatisch leidt tot meer ondergrondverdichting dan NKG. Het is zelfs zo dat NKG hier slechter presteert dan ploegen. Een belangrijke conclusie is echter ook dat het onderzoek te beperkt van opzet is om harde statistisch significante conclusies te kunnen trekken. Hieronder volgt een aantal aanbevelingen die direct voortkomen uit de resultaten van het onderzoek. Deze onderdelen worden in de laatste alinea van deze paragraaf gebundeld tot een algehele aanbeveling.

\section{Simulaties met grondwaterstand als randvoorwaarde}

Voor de locatie Vredepeel wordt aanbevolen om aanvullende simulaties uit te voeren met de grondwaterstand als randvoorwaarde. Uit de simulatie van voorliggend onderzoek volgt namelijk dat de gesimuleerde grondwaterstand minder diep wegzakt dan de gemeten grondwaterstand in de jaren 2018 en 2019. Het effect van beregening buiten het onderzoeksperceel op de grondwaterstanden is niet in de huidige simulaties meegenomen. Mogelijk is dit de oorzaak van de discrepantie. Met de extra simulaties kan bekeken worden in hoeverre de drukhoogten in de ondiepere lagen beïnvloed worden door deze nieuwe randvoorwaarde, en daarmee ook welke invloed dat heeft op de vochtopname door de wortels. De gevoeligheid van het gewas voor grondwaterstanddaling door onttrekkingen voor de beregening kan dan ook ingeschat worden. De beste resultaten worden behaald als er scenarioberekeningen worden gedaan met en zonder beregening en voor verschillende weerjaren.

\section{Modelkalibratie}

- Voor de locatie Lelystad zijn drukhoogtemetingen beschikbaar voor slechts een beperkte en relatief natte periode. Aanbevolen wordt om ook in een drogere periode tensiometermetingen uit te voeren met als doel om na te gaan of het model ook in een droge zomerperiode het bodemwatersysteem goed kan simuleren.

- Oppervlaktewaterstanden in de sloten rond de percelen: mogelijk dat in verband met droogtebestrijding de oppervlaktewaterpeilen (recent) gedurende droge perioden hoog opgezet worden.

- Neerslaggegevens: de verschillende databronnen voor de neerslag geven geen eenduidig beeld voor 2020. Een accuraat beeld van neerslaghoeveelheden is onontbeerlijk.

- Opbrengsten: grondwateronttrekkingen ten behoeve van beregening. De onttrekkingen buiten de onderzoekspercelen in Vredepeel beïnvloeden de grondwaterstanden op de onderzoekslocatie.

\section{Structuurvorming}

Aanbevolen wordt om bij de veldschouw meer aandacht te besteden aan structuurvorming. De indringweerstand in het interval cultivatiediepte-ploegdiepte lijkt namelijk bij NKG hoger dan bij ploegen. Het is niet duidelijk of een betere structuur bij NKG de oorzaak is van de hogere indringweerstand. De hogere verzadigde waterdoorlatendheid bij NKG wijst wel in deze richting. De gevonden worteldiepte in Vredepeel (zandgrond) aan het eind van het groeiseizoen is echter tegenstrijdig aan deze aanname: bij NKG was deze beperkt tot $30 \mathrm{~cm}$ diepte, terwijl dit bij ploegen $40 \mathrm{~cm}$ was. Wel moet daarbij bedacht worden dat een zandgrond normaliter weinig structuurvorming laat zien.

\section{Variabiliteit in opbrengstgegevens}

Voor zowel Lelystad als Vredepeel blijkt de variatie in opbrengsten per proefveld sterk te verschillen. Aanbevolen wordt deze variabiliteit gedetailleerder te onderzoeken, zodat beter inzicht wordt verkregen in de verschillen per behandeling en randvoorwaarden. 


\section{Bundeling van krachten is nodig}

Uit het onderzoek blijkt dat er wat betreft ondergrondverdichting aanwijzingen zijn dat het traditionele ploegen beter scoort dan NKG en ondiep ploegen. NKG+cultiveren lijkt beter te scoren dan NKG zonder cultiveren. Het onderzoek is echter te beperkt van omvang geweest om significante uitspraken te kunnen doen. Omdat een totaalbeeld van relevante parameters in voldoende herhalingen in ruimte en tijd onderzoekstechnisch een stuk efficiënter is dan vele kleine onderzoeken, pleiten de onderzoekers ervoor om krachten te bundelen in een groot onderzoek naar ondergrondverdichting, zodat wel sluitende uitspraken gedaan kunnen worden. Uitgebreide metingen van alle hydrofysische bodemkwaliteiten, opbrengsten en randvoorwaarden in de tijd zijn weliswaar kostbaar, maar erg waardevol. De praktijk heeft grote behoefte aan het kunnen maken van gefundeerde keuzen voor managementopties. 


\section{Literatuur}

Akker, van den \& de Groot, 2008: Een inventariserend onderzoek naar ondergrondverdichting van zandgronden en lichte zavels. Wageningen-UR, Alterra Rapport 1450. https://edepot.wur.nl/60379

Amami, Roua, Khaled Ibrahimi, Abdelhamid Znouda, Khaoula Abrougui \& Chehaibi Sayed, 2021. Influence of tillage systems on soil bulk density and carbon dioxide emissions in the Mediterranean context. Euro-Mediterr J Environ Integr 6, 16. https://link.springer.com/article/10.1007/s41207020-00229-0

Bakker, G., M. Heinen, H. P. A. Gooren, W. J. M. de Groot \& P. D. Peters, 2020. Hydrofysische gegevens van de bodem in de Basisregistratie Ondergrond (BRO) en het Bodemkundig Informatie Systeem (BIS): Update 2019. WOt-technical report; No. 186. Wettelijke Onderzoekstaken Natuur \& Milieu. https://doi.org/10.18174/526509

Balen, Derk van \& Wiepie Haagsma. 2015-1. Nieuwsbrief BASIS; Teelt van biologische zomertarwe in NKG. Praktijkonderzoek Plant \& Omgeving, Wageningen UR, Lelystad. https://edepot.wur.nl/353678

Balen, Derk van \& Wiepie Haagsma. 2015-2. Nieuwsbrief BASIS; Teelt van biologische peen in NKG. Praktijkonderzoek Plant \& Omgeving, Wageningen UR, Lelystad. https://edepot.wur.nl/353676.

Balen, Derk van, Paulien van Asperen, Wiepie Haagsma, Marie Wesselink, Fogelina Cuperu, 2020. Telen van aardappel zonder ploegen. https://edepot.wur.nl/548352

Bastiaansen, Lucas, 2019. Afstudeeronderzoek rijpadensysteem; Het effect van rijpaden op onbereden teeltbedden. Aeres Hogeschool, Dronten.

https://www.beterbodembeheer.nl/upload_mm/6/4/9/48a6e0c2-94a3-4921-bac2-

f1f37863d111_Afstudeerwerkstuk\%20Lucas\%20Bastiaansen\%20V3.pdf

Bongiornoa, Giulia, Else K. Bünemann, Chidinma U. Oguejiofor, Jennifer Meier, Gerrit Gort, Rob Comans, Paul Mäder, Lijbert Brussaard, Ron de Goede, 2019. Sensitivity of labile carbon fractions to tillage and organic matter management and their potential as comprehensive soil quality indicators across pedoclimatic conditions in Europe.

Crittenden, Stephen J., 2015. Biophysical soil quality of tillage systems in conventional and organic farming. Thesis, Wageningen University, Wageningen. https://edepot.wur.nl/36418

Haan, Janjo de, Marie Wesselink, Wim van Dijk, Harry Verstegen, Willem van Geel, Wim van den Berg, 2017. Biologisch teelt op zuidelijke zandgronden: opbrengst, bemesting, bodemkwaliteit en stikstofverliezen; Resultaten van het biologische bedrijfssysteem van het project Bodemkwaliteit op zand in de periode 2000-2016. Wageningen Research, Rapport WPR-755. https://edepot.wur.nl/440225

Heinen, M., G. Bakker, 2018. Interne WENR-memo "Bodemfysische metingen".

Heinen, M., G. Bakker, J.H.M. Wösten, 2020. Waterretentie- en doorlatendheidskarakteristieken van boven- en ondergronden in Nederland: de Staringreeks - Update 2018.

https://edepot.wur.nl/512761

Hoek, J., D. van Balen, W. Haagsma, W. van den Berg, P. van Asperen, W. Sukkel, J. de Haan, J. Bloem, 2019. Bodemindicatoren in BASIS; Identificatie van de belangrijkste biologische en chemischebodemparameters ("bodemindicatoren") in het project BASIS over de periode 2009 2016. Wageningen Research. Wageningen Research rapport, WPR -79. https://edepot.wur.nl/511496

Kroes, J.G., J.C. Van Dam, P. Groenendijk, R.F.A. Hendriks \& C.M.J. Jacobs, 2008. SWAP version 3.2. Theory description and user manual. Wageningen, Alterra. Alterra Report 1649. https://edepot.wur.nl/39776

Norén, I. Selin, Daan Verstand, Janjo de Haan, 2021. Effecten van bodemmaatregelen op bodemfuncties en bodemkwaliteit: integrale analyse van de resultaten uit de PPS Beter Bodembeheer en eerste vertaalslag naar praktische boodschappen. Wageningen, Wageningen Plant Research, Rapport WPR-856. https://doi.org/10.18174/536510

Stuyt, L.C.P.M., M. Knotters, D.J.J. Walvoort, F. Brouwer \& H.T.L. Massop (2018). Basisregistratie Ondergrond - Gd-kartering Laag-Nederland 2018; Provincie Flevoland. WOt-technical report 145. WOT Natuur \& Milieu, WUR, Wageningen. https://edepot.wur.nl/470403 
Wolf, P. de, A. Dawson, K. Klompe, 2019. Kosten en baten van bodemmaatregelen; Grondbewerking, organische stofaanvoer en Tagetes patula als aaltjesvanggewas. Wageningen Research, Rapport WPR-819. https://library.wur.nl/WebQuery/wurpubs/fulltext/511834 


\section{Bijlage 1 Maaiveldhoogte Lelystad}

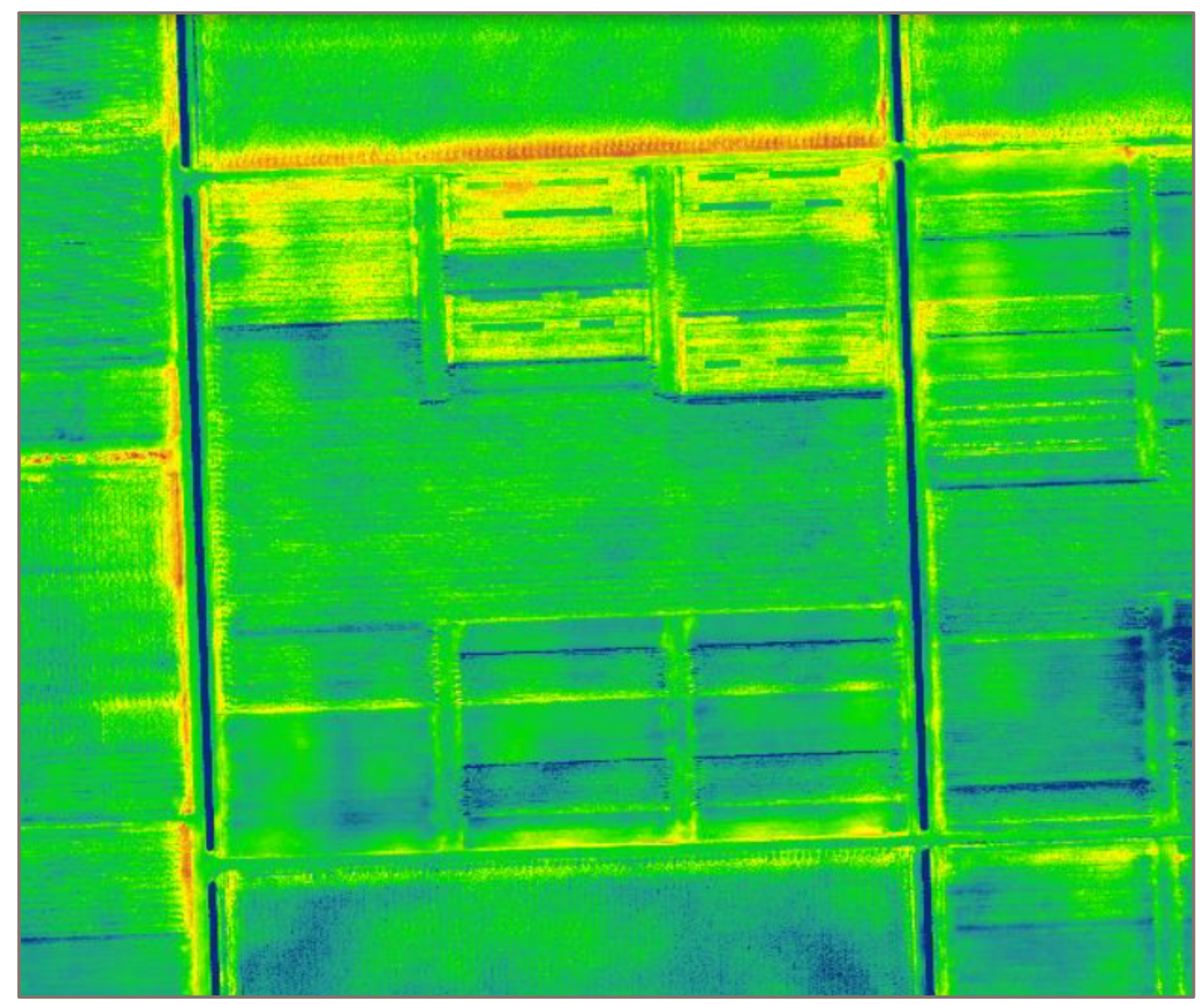

Figuur B1.1 Maaiveldhoogte (in kleur de relatieve verschillen). 


\section{Bijlage 2 Hydrofysische analysemethoden}

\section{Korrelgrootteverdeling}

De fracties < $63 \mu \mathrm{m}$ worden in het Chemisch Biologisch Laboratorium Bodem (CBLB, onderdeel van Wageningen University \& Research, WUR) geanalyseerd volgens de pipet- en natte-zeefmethode. De fracties in het bereik 63-2000 $\mu \mathrm{m}$ worden daarna in het bodemhydrofysisch Laboratorium van WUR verder geanalyseerd door middel van droogzeven.

Tabel B2.1 Gehanteerde fracties voor BIS en de gebruikte labmethode.

\begin{tabular}{ll} 
Textuurklasse $(\mathrm{\mu m})$ & Gebruikte methode \\
$<2$ & Pipetmethode \\
\hline $2-16$ & Pipetmethode \\
\hline $16-50$ & Pipetmethode \\
\hline $50-63$ & Natte-zeefmethode \\
\hline $63-105$ & Droge-zeefmethode \\
\hline $105-150$ & Droge-zeefmethode \\
\hline $210-210$ & Droge-zeefmethode \\
\hline $420-2000$ & Droge-zeefmethode \\
\hline
\end{tabular}

Voor de bepaling is de procedure als volgt:

Een droog bulkmonster wordt ontdaan van de fractie $>2000$ um. Vervolgens worden organische stof, carbonaten en ijzer verwijderd. Dit geeft een puur mineraal monster. Uit het minerale deel worden de kleinere fracties bepaald. De massafracties die uit het lab komen (\%), zijn de minerale deelfracties gedeeld door het droge bulkmonster <2000:

Fracti $_{i, l a b}=\frac{m_{i, \min }}{m_{\text {bulk, }<2000}} \cdot 100 \%$

De som van alle deeleenheden geeft de bulkmassa:

$m_{\text {bulk }}=m_{>2000}+m_{\text {OS }}+m_{\text {carbonaten }}+m_{i j z e r}+\sum m_{i, \min }$

Om de textuurbenaming te kunnen afleiden, worden alle deelfracties tezamen geschaald naar $100 \%$. Deze 'fracties op de minerale delen' worden in dit rapport gepresenteerd.

Uit de laboratoriumbepalingen wordt ook het M50-getal berekend. Het M50-getal wordt overigens ook door de veldmedewerker geschat. Het M50-getal is de mediane fractie in het bereik 50-2000 $\mu \mathrm{m}$, ofwel de korrelgrootte waarboven $50 \%$ van het gewicht zich bevindt binnen dit bereik.

\section{Gloeiverlies NEN 5754 (1992)}

Het gloeiverlies (Eng: loss-on-ignition) is een maat voor het organischestofgehalte van een grondmonster. Hoe groter het aandeel organisch materiaal, hoe groter het gloeiverlies zal zijn. In het laboratorium wordt het in het veld genomen verstoorde grondmonster gezeefd over een zeef met $2 \mathrm{~mm}$ maaswijdte. De fractie kleiner dan $2 \mathrm{~mm}$ wordt gedroogd bij $105^{\circ} \mathrm{C}$, gewogen en vervolgens gegloeid bij $550^{\circ} \mathrm{C}$. Het gloeiverlies $w_{g v}$ wordt vervolgend berekend uit

$w_{g v}=\frac{m_{105}-m_{550}}{m_{105}-m_{0}} \times 100 \%$ 
waarin:

$w_{g v} \quad=$ gloeiverlies op basis van stoofdroge grond (\%);

$m_{0} \quad=$ massa van het lege kroesje $(\mathrm{g})$;

$m_{105}=$ massa van het kroesje met het stoofdroge monster $(\mathrm{g})$;

$m_{550}=$ massa van het kroesje met het gegloeide monster $(\mathrm{g})$.

Het organischestofgehalte is dus gegeven op de bulkfractie $<2000$ en is per definitie kleiner of gelijk aan het gloeiverlies. Het organischestofgehalte kan volgens de NEN 5754 (1992) benaderd worden door de gloeiverliesbepaling vergezeld te laten gaan van een lutumgehaltebepaling en een bepaling van het gehalte aan vrij ijzer. Het OS-gehalte wordt dan als volgt berekend:

$w_{O S}=w_{g v}-0.07 * L-0.12 * Y$

waarin:

WOS = organischestofgehalte van stoofdroge grond (\%)

$L \quad=$ lutumgehalte $(\%)$

$Y \quad=$ gehalte aan vrij ijzer (\%) (Alleen corrigeren bij $Y>5 \%$.)

\section{Retentie- en onverzadigde waterdoorlatendheidskarakteristiek}

De retentiekarakteristiek wordt bepaald met behulp van drie verschillende laboratoriumopstellingen:

- Zandbak voor het bereik $h=0$ tot $-100 \mathrm{~cm}$;

- Verdampingsopstelling voor het bereik $h=-10$ tot $-700 \mathrm{~cm}$;

- Drukpanopstelling voor het bereik $h=-1000$ tot $-15000 \mathrm{~cm}$.

De karakteristiek voor de onverzadigde waterdoorlatendheid wordt bepaald met behulp van de verdampingsopstelling voor het bereik $h=-50$ tot $-700 \mathrm{~cm}$. De metingen vinden plaats in het bodemhydrofysisch Laboratorium van WUR onder strenge temperatuur- en vochtigheidscondities.

\section{Zandbakmethode en droge bulkdichtheid (ISO 11272, ISO 11274)}

Voor deze methode wordt een onverstoord gestoken grondmonster van $100 \mathrm{~cm}^{3}$ in een roestvrijstalen monsterring $(L=5 \mathrm{~cm}, D \approx 5 \mathrm{~cm}$ ) met het nylongaasje op de zandbak geplaatst. Door middel van een drainagebuis die verbonden is met een waterreservoir, kan het bodemwater op elke gewenste zuigspanning worden gebracht. Zodra het monster in evenwicht is met de aangelegde zuigspanning, wordt het monster gewogen. Vervolgens wordt een nieuwe zuigspanning aangelegd en wordt de procedure herhaald. Zodra alle zuigspanningen op deze wijze zijn doorgemeten, wordt het monster gedroogd bij $105^{\circ} \mathrm{C}$ en wordt het opnieuw gewogen. Dit resulteert in de droge bulkdichtheid en het natte deel van de retentiekarakteristiek. Zowel het volumetrisch watergehalte als de droge bulkdichtheid wordt altijd bepaald ten opzichte van het referentievolume van de grond bij verzadiging.

\section{Verdampingsmethode (ISO 11275, 2004)}

De verdampingsmethode wordt gebruikt om een deel van de retentie- en onverzadigde waterdoorlatendheidskarakteristiek te bepalen. Voor deze methode wordt een onverstoord gestoken grondmonster van circa $600 \mathrm{~cm}^{3}$ in een pvc-monsterring $(L=8 \mathrm{~cm}, D \approx 10 \mathrm{~cm})$ op de meetopstelling geplaatst. Alleen de bovenzijde staat bloot aan de omgevingslucht. De drukhoogten en het gewicht worden in het monster gemeten met vier horizontaal georiënteerde tensiometers die op gelijke verticale afstanden worden geplaatst. 


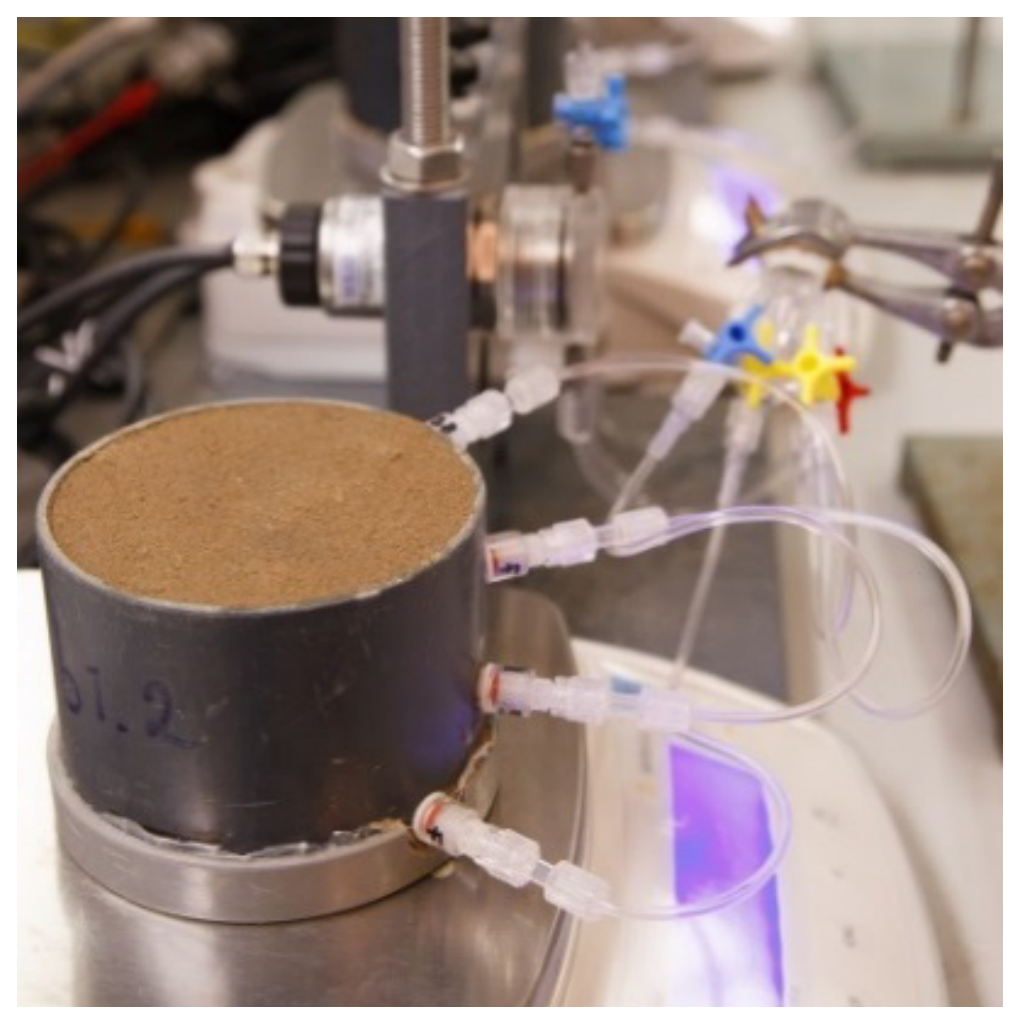

Figuur B2.1 Geautomatiseerde opstelling voor de verdampingsmethode (Foto: Erik van den Elsen).

Zodra de water gevulde tensiometers stoppen met werken, meestal in de buurt van de $\mathrm{h}=-700$ tot $-900 \mathrm{~cm}$, bepaalt men het ovendroge gewicht van het monster, zodat het gemiddelde watergehalte op elk tijdstip is terug te rekenen en de onverzadigde doorlatendheid kan worden berekend. De ruwe data (tijd, monstermassa, drukhoogten) worden verkregen met een geautomatiseerde opstelling die door WUR in eigen beheer is ontwikkeld (zie Figuur 3.1). In paragraaf 3.5 wordt nader omschreven hoe uit de ruwe meetdata (totale monstergewichtsafname (verdamping) en drukhoogtes op 4 dieptes) datapunten voor de waterretentiekarakteristiek en doorlatendheidskarakteristiek worden afgeleid.

\section{Drukpanmethode ISO 11274}

Met een hangende waterkolom, zoals aangebracht met de zandbakopstelling (zie paragraaf over de Zandbakmethode), kan een maximale theoretische zuigspanning van $1000 \mathrm{~cm}$ worden aangebracht. Vanaf dat punt zal het water gaan koken en is een betrouwbare meting niet meer mogelijk. Om toch bij grotere zuigspanningen te kunnen meten, wordt met een overdruk in plaats van een onderdruk gewerkt. Verschillende kleine verzadigde bodemmonsters worden op een met water verzadigde keramische plaat geplaatst. De keramische plaat wordt vervolgens in een drukpan gemonteerd. Door middel van een overdruk in de drukpan wordt er een waterpotentiaal aangebracht op het monster. Zodra het monster in evenwicht is met de aangelegde druk, wordt de druk weggenomen en worden de monsters gewogen en gedroogd bij $105^{\circ} \mathrm{C}$ en nogmaals gewogen. Om het volumetrisch vochtgehalte te kunnen bepalen, is dan wel nog de droge bulkdichtheid van een onverstoord monster nodig (meestal de droge bulkdichtheid van het monster dat bij de verdampingsmethode of de zandbakmethode is gebruikt):

$\theta=\frac{\rho_{d}}{\rho_{l}} w$

waarin:

$\rho_{d} \quad=$ droge bulkdichtheid $\left(\mathrm{kg} \mathrm{m}^{-3}\right)$

$\rho_{l} \quad=$ dichtheid van water $\left(\mathrm{kg} \mathrm{m}^{-3}\right)$

$w \quad=$ watergehalte op gewichtsbasis en is gelijk het gewicht van het water in het monster gedeeld door het gewicht aan van de ovendroge grond $\left(\mathrm{kg} \mathrm{kg}^{-1}\right)$

Bij deze hoge zuigspanningen kunnen kleine, verstoorde grondmonsters worden gebruikt. De methode wordt gebruikt voor het meetbereik van $h=-1000$ tot $-15000 \mathrm{~cm}(3 \leq \mathrm{pF} \leq 4,2)$. De benodigde droge 
bulkdichtheid is beschikbaar vanuit gerelateerde monsters die zijn gebruikt voor de zandbakmethode en/of de verdampingsmethode.

\section{Verzadigde waterdoorlatendheid}

Een niet-verstoord, homogeen grondmonster in een ring $(H=10 \mathrm{~cm} ; D=20 \mathrm{~cm})$ wordt in een opstelling geplaatst. Het monster wordt geheel verzadigd met water. Boven op het grondmonster wordt een waterlaag met constante hoogte gehandhaafd. Bovendien wordt de onderzijde van het monster geheel verzadigd gehouden. Er wordt een constante stijghoogtegradiënt ingesteld door de uitstroomslang op een vaste positie te houden. Door de hoeveelheid uitstromend water per tijdseenheid te meten, kan de verzadigde waterdoorlatendheid $K_{s}$ volgens de wet van Darcy worden bepaald:

$k_{s}=\frac{V}{|\nabla H| \cdot \Delta t \cdot A}$

waarin:

$k_{s} \quad=$ verzadigde waterdoorlatendheid $\left(\mathrm{cm} \cdot \mathrm{d}^{-1}\right) ; \mathrm{d}=24$ uur

$V \quad=$ volume water dat gedurende $\Delta t$ is uitgestroomd $\left(\mathrm{cm}^{3}\right)$

$|\nabla H|=$ absolute hydraulische stijghoogtegradiënt $\left(\mathrm{cm} \mathrm{cm}^{-1}\right)$

$A=$ oppervlakte van het grondmonster $\left(\mathrm{cm}^{2}\right)$

$\Delta t \quad=$ tijd waarin het uitstromende water is gemeten $(\mathrm{d})$

Voor de meting wordt afgeweken van de NEN 5789 (1991). De NEN gaat uit van vrije uitstroom aan de onderzijde van het monster. Omdat in dat geval onverzadigde delen aan de onderzijde van het monster ontstaan en de te overwinnen cohesie- en adhesiekrachten aan de onderzijde ongelijk aan nul zijn, is de gemeten waterdoorlatendheid lager dan de werkelijke verzadigde waterdoorlatendheid. Door de onderzijde verzadigd te houden, wordt dit probleem ondervangen (De Vos, 1997).

\section{Afgeleide gegevens}

$\mathrm{Na}$ de metingen in het laboratorium worden de meetgegevens gebruikt om datareeksen voor retentiecurven en doorlatendheidscurven vast te stellen. Hiervoor is achtereenvolgens een aantal (rekenkundige) bewerkingen nodig:
a. Data-filtering;
b. Genereren datareeksen $h(\theta)$ voor retentiekarakteristiek per bodemcompartiment door het uitvoeren van een PreFit;
c. Genereren van datareeksen $\mathrm{K}(\mathrm{h})$ voor de doorlatendheidskarakteristiek tussen de bodemcompartimenten door het toepassen van de zogenaamde 'instantaneous profile'-methode;
d. Genereren Mualem-Van Genuchten-parameters door het uitvoeren van een EindFit.

De volledige beschrijving is weergegeven in een interne WENR-memo (Heinen \& Bakker, 2018). 


\section{Bijlage 3 Meteogegevens Lelystad}

In de onderstaande figuren zijn de meteorologische gegevens weergegeven over de jaren 2005-2020:

- Jaarlijkse neerslag en verdamping

- Maandelijkse neerslag in een boxplot

- Netto neerslag (neerslag minus verdamping) in het zomerhalfjaar

- Netto neerslag (neerslag minus verdamping) in het gehele jaar

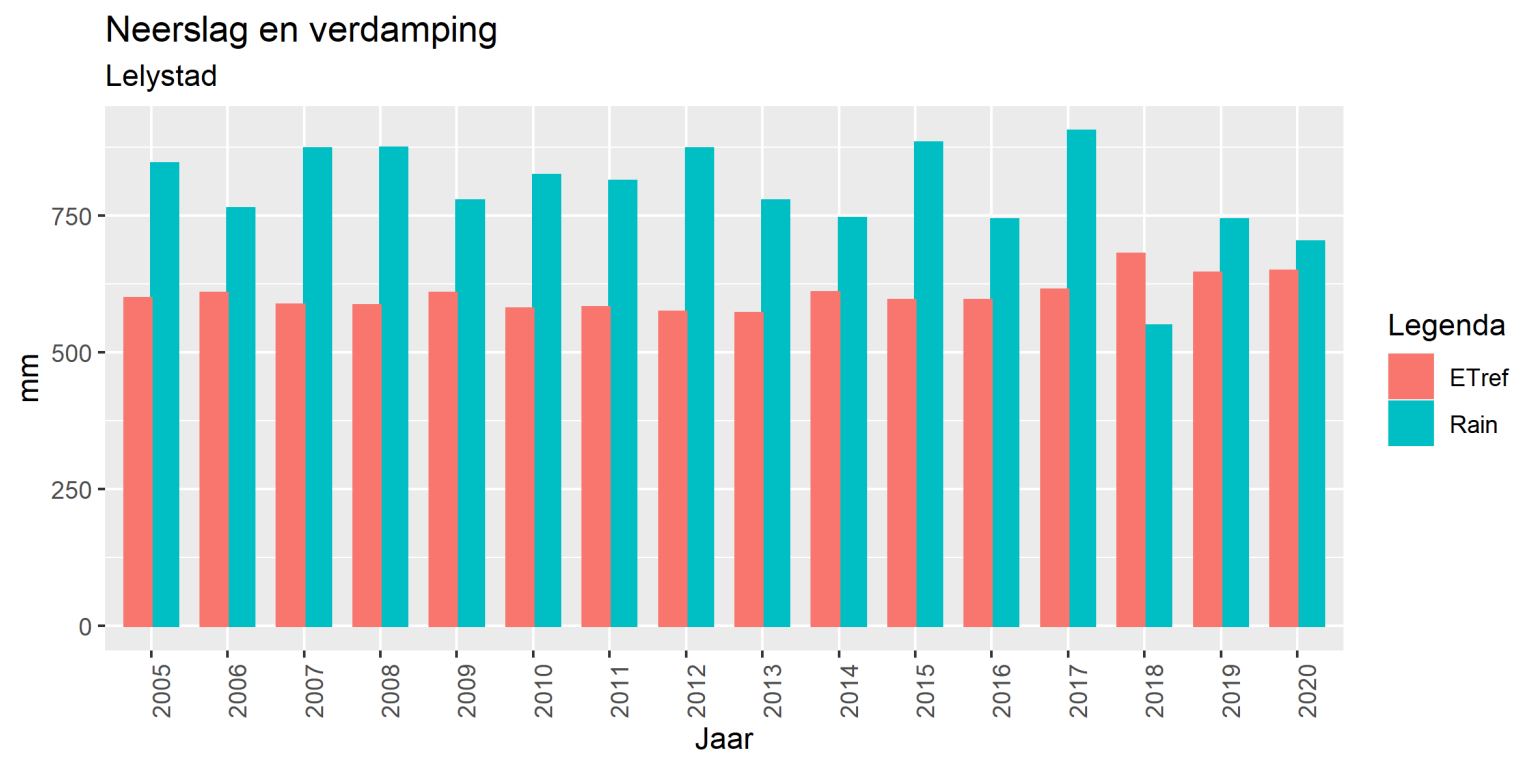

Figuur B3.1 Jaarlijkse neerslag en verdamping (Lelystad, bron: KNMI).

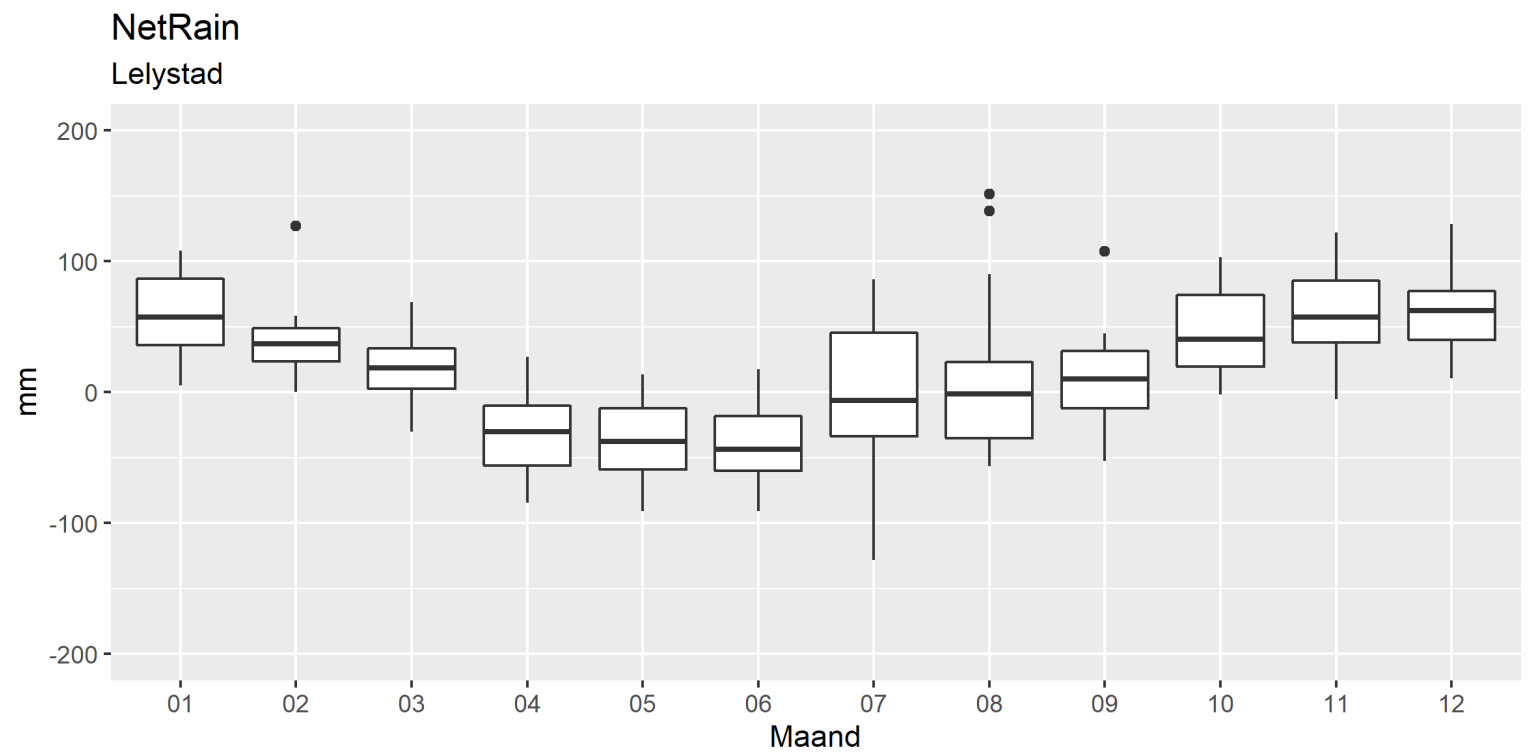

Figuur B3.2 Maandelijkse netto neerslag Lelystad (neerslag minus referentieverdamping, boxplot jaren 2005-2020, bron: KNMI). 


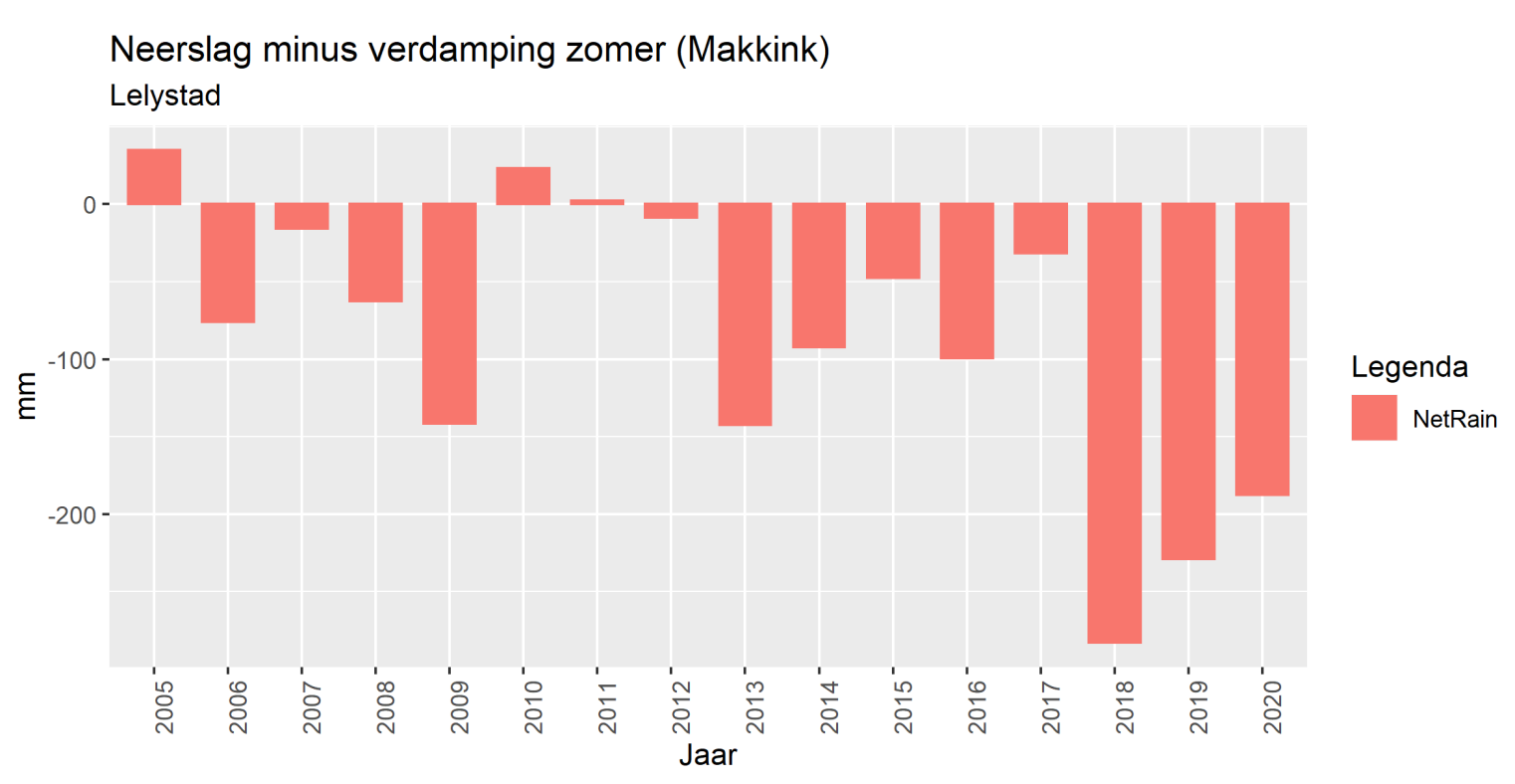

Figuur B3.3 Netto neerslag zomer Lelystad (april tot en met september, neerslag minus referentieverdamping, bron: KNMI).

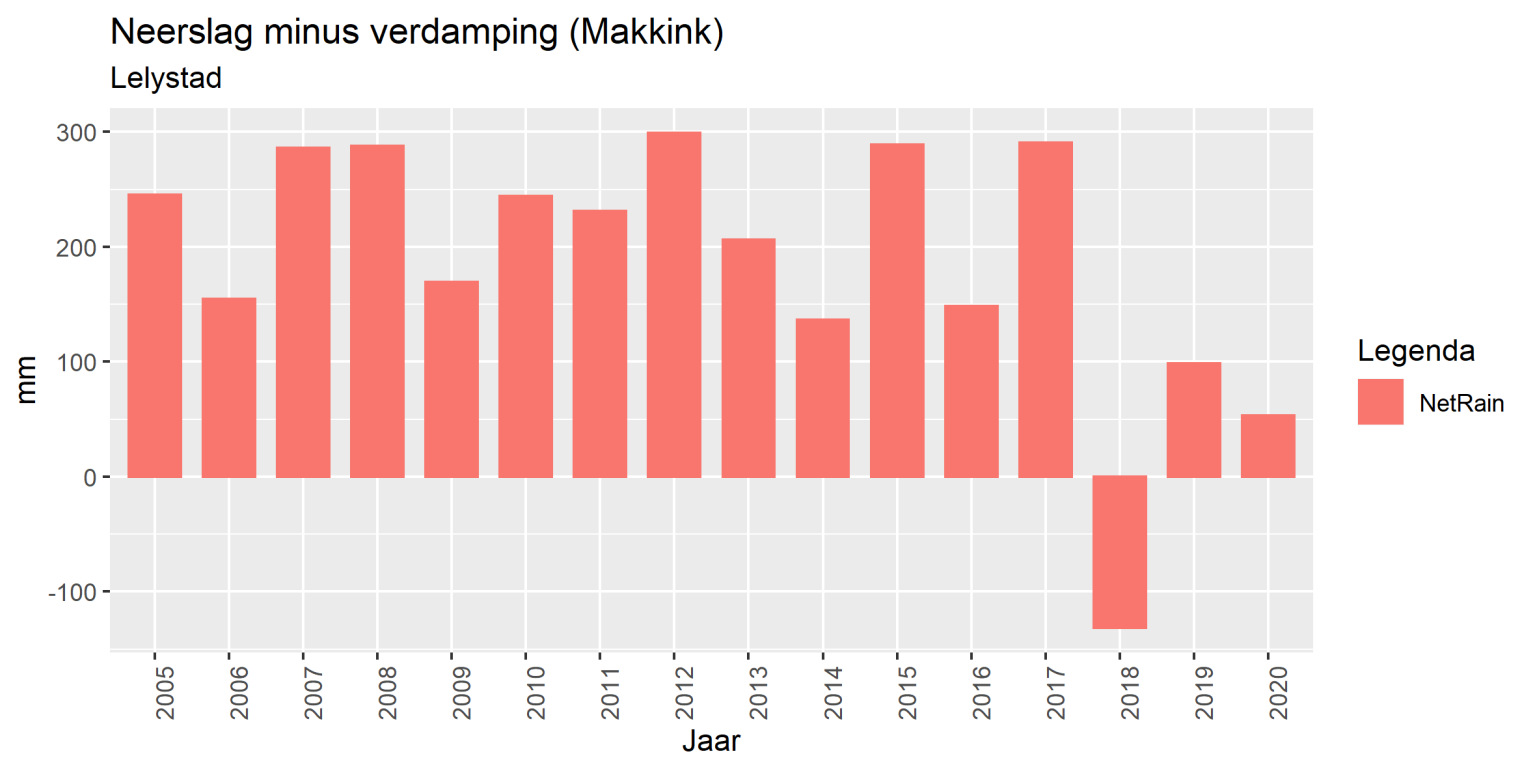

Figuur B3.4 Jaarlijkse netto neerslag (neerslag minus referentieverdamping, bron: KNMI). 


\section{Bijlage 4 Lithologie Lelystad}

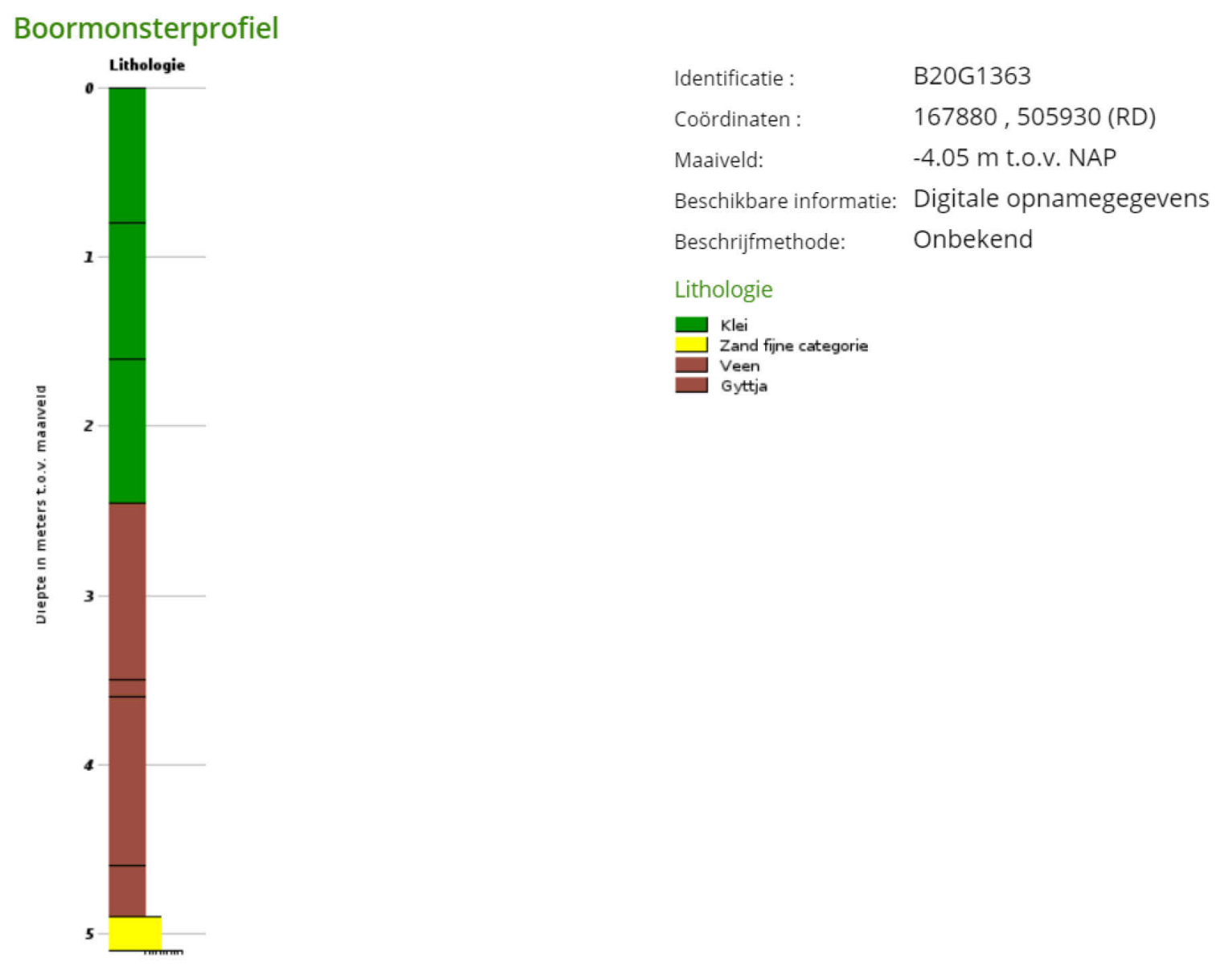




\section{Bijlage 5 Onderdruk Lelystad}

In het najaar van 2019 zijn na de oogst tensiometermetingen uitgevoerd.

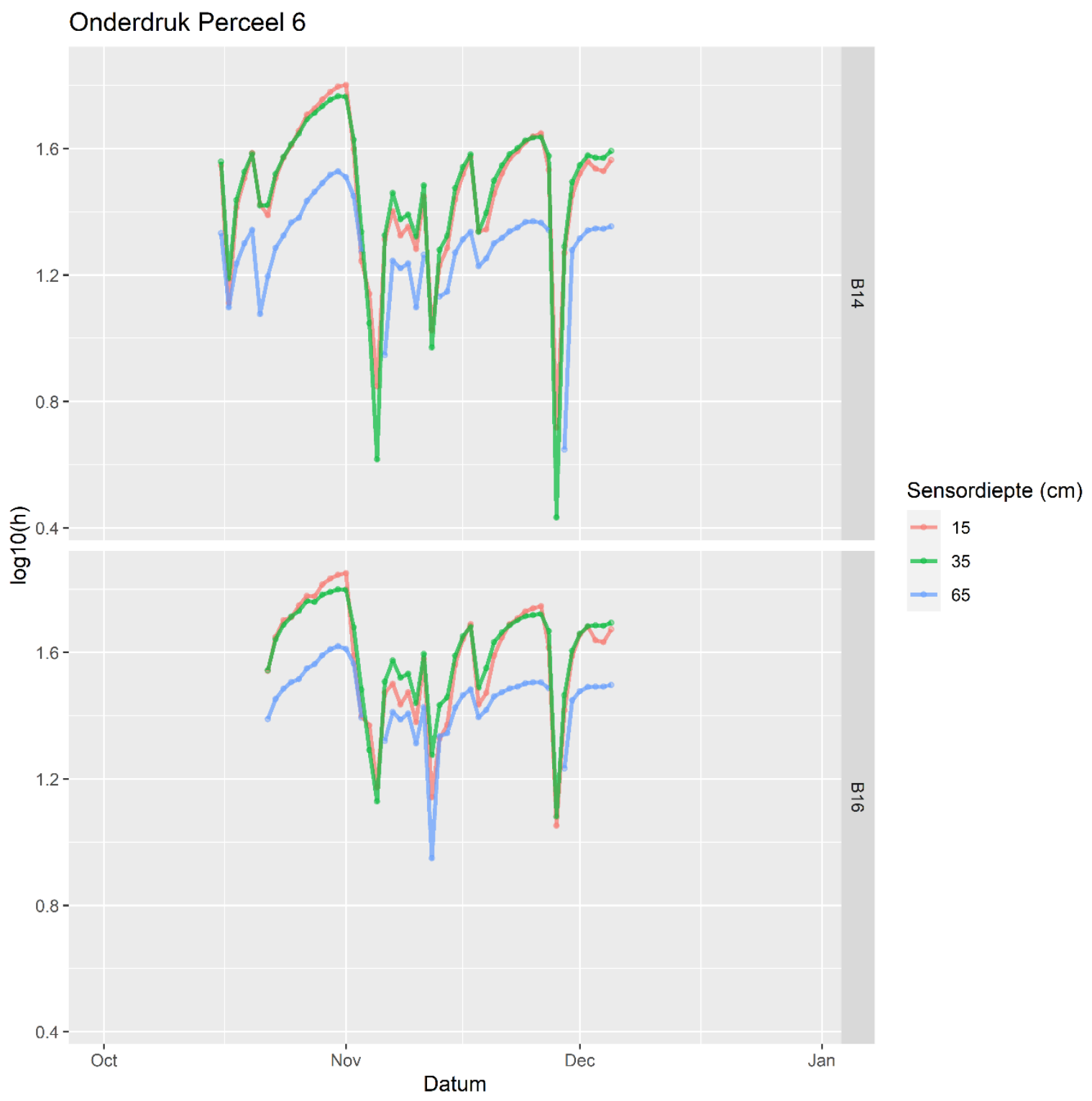

Figuur B5.1 Gemeten drukhoogten op log-schaal Lelystad. 


\section{Bijlage 6 Indringweerstanden Lelystad}

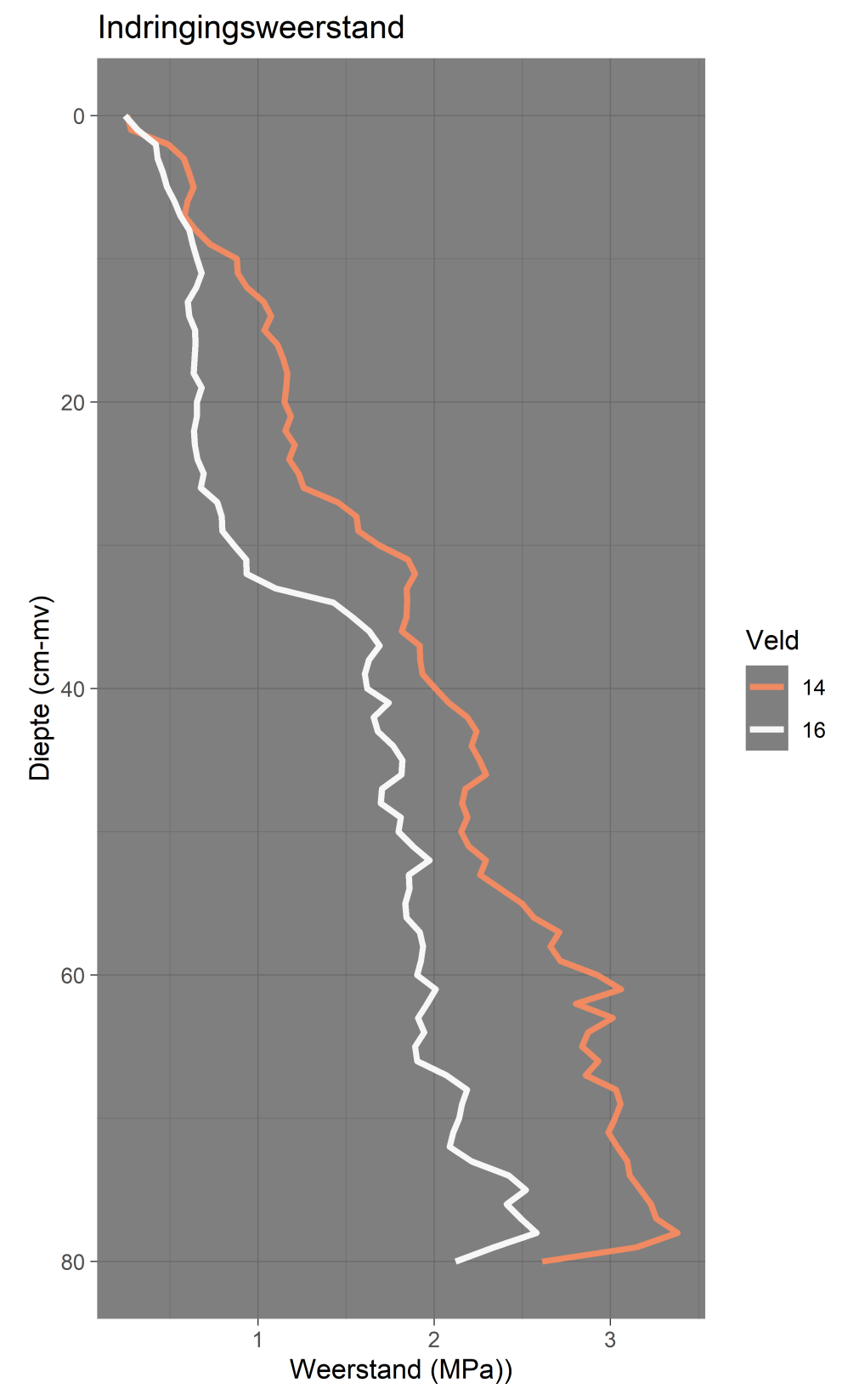

Figuur B6.1 Mediane indringweerstand op blok 14 NKGO en 16 Ploeg25.

In Figuur B6.2 is de indringweerstand weergegeven voor de blokken 14 en 16 waarbij een onderscheid is gemaakt in de eerste helft van de proefperiode en de tweede helft. Wat opvalt, is dat bij blok 16 (Ploeg25) de indringweerstand voor de bovenste $25 \mathrm{~cm}$ niet is veranderd (dat is ongeveer de grondbewerkingsdiepte), maar dieper wel iets toegenomen lijkt te zijn. Voor blok 14 (NKG0) geldt alleen voor de bovenste $10 \mathrm{~cm}$ dat er geen verandering is (dat is ongeveer de grondbewerkingsdiepte). De toename van de indringweerstand van $10 \mathrm{~cm}$ tot $25 \mathrm{~cm}$ levert geen problemen op voor de bewortelbaarheid tot $25 \mathrm{~cm}-\mathrm{mv}$. De verwachting bij NKG is dat de bodemstructuur in de loop der jaren zal verbeteren. Een verklaring voor de toename is niet te geven met de huidige set gegevens. De aanwezigheid van meer macroporiën bij NKG heeft naar verwachting geen tot minimaal effect op de indringweerstand. 


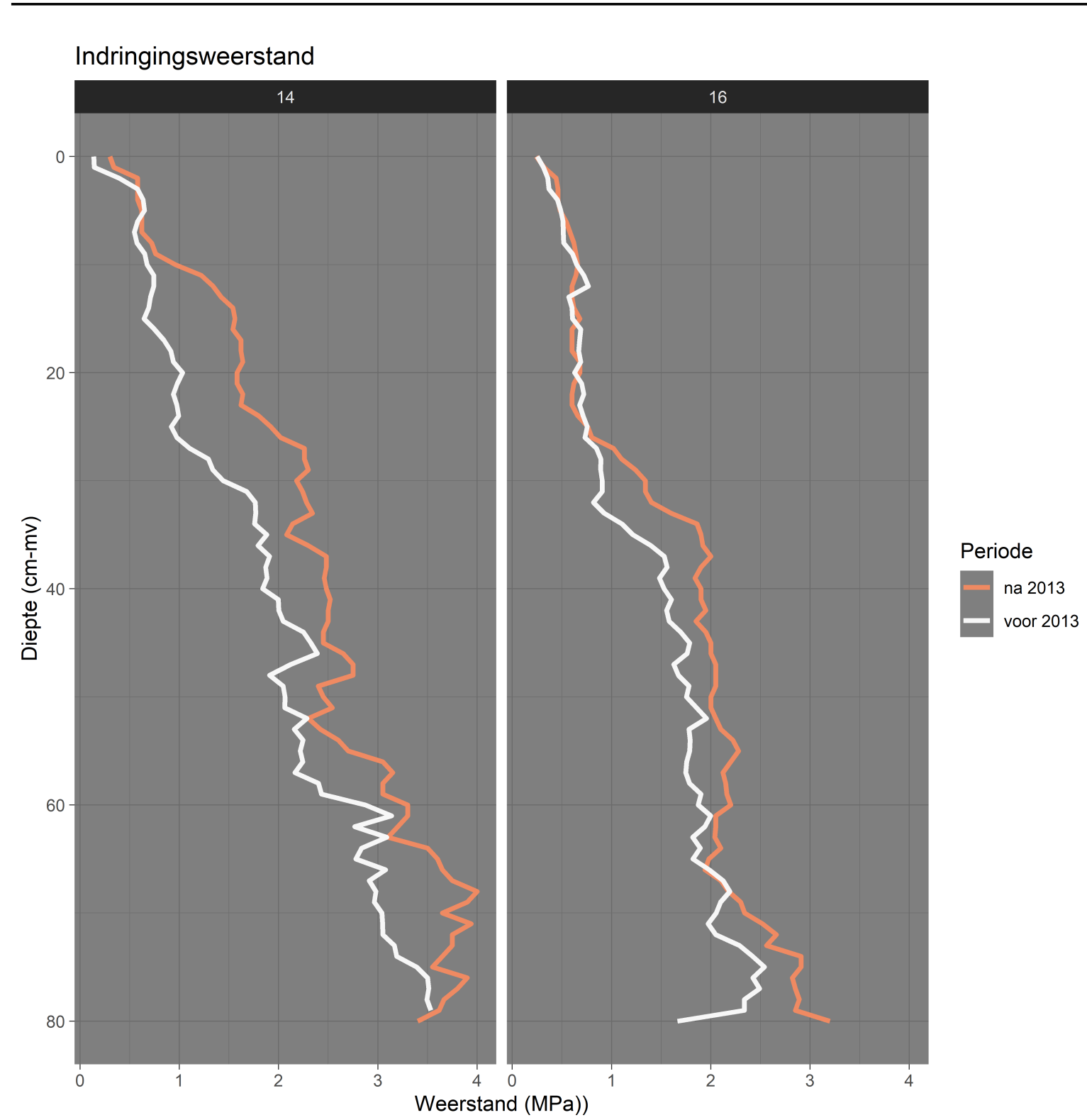

Figuur B6.2 Mediane indringweerstand op blok 14 (NKGO) en 16 (Ploeg25) met onderscheid in metingen voor 01-01-2013 (wit) en na 31-12-2013 (oranje). 


\section{Bijlage 7 Bodemprofielen Vredepeel}

Tabel B7.1 Bodemprofielen (veldschattingen) Vredepeel mei 2020.

\begin{tabular}{|c|c|c|c|c|c|c|c|c|}
\hline Plot & Grondbewerking & Laag & Diepte $(\mathrm{cm})$ & Horizont & Org. stof $(\%)$ & Leem $(\%)$ & BOOR_METH & Bouwsteen \\
\hline 40 & NKG15 & 1 & $0-30$ & $1 \mathrm{Ap}$ & 6.0 & 12 & EDM & NKG_B010 \\
\hline 40 & NKG15 & 2 & $30-55$ & 1Bhs/Ce & 1.0 & 12 & EDM & NKG_B01m \\
\hline 40 & NKG15 & 4 & $140-150$ & $1 \mathrm{Cr}$ & 0.1 & 8 & EDM & NKG_O1d \\
\hline 48 & Ploeg30 & 1 & $0-30$ & $1 \mathrm{Ap}$ & 5.0 & 12 & EDM & PI_B010 \\
\hline 48 & Ploeg30 & 3 & $60-140$ & $1 \mathrm{Ce}$ & 0.1 & 8 & EDM & PI_01d \\
\hline 48 & Ploeg30 & 4 & $140-150$ & $1 \mathrm{Cr}$ & 0.1 & 8 & EDM & PI_O1d \\
\hline
\end{tabular}




\section{Bijlage 8 Neerslaggegevens Vredepeel}

In Figuur B8.1 en Figuur B8.2 zijn de jaar- en zomerneerslagoverschotten gegeven voor Volkel. Uit beide figuren valt op dat de laatste drie jaren een negatief neerslagoverschot (meer verdamping dan neerslag) hebben voor zowel het jaargemiddelde als het zomergemiddelde.

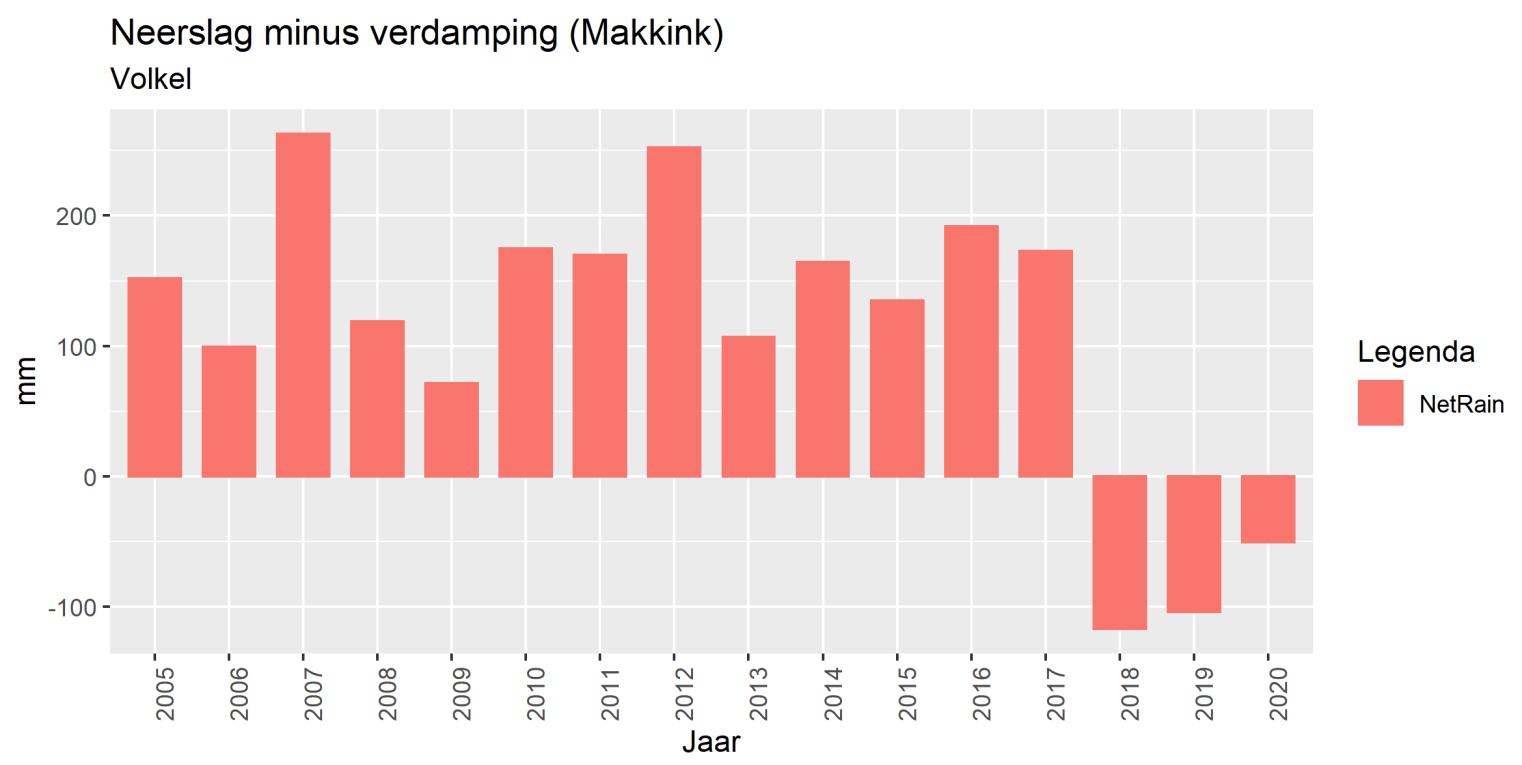

Figuur B8.1 Netto neerslag per jaar voor meteostation Volkel.

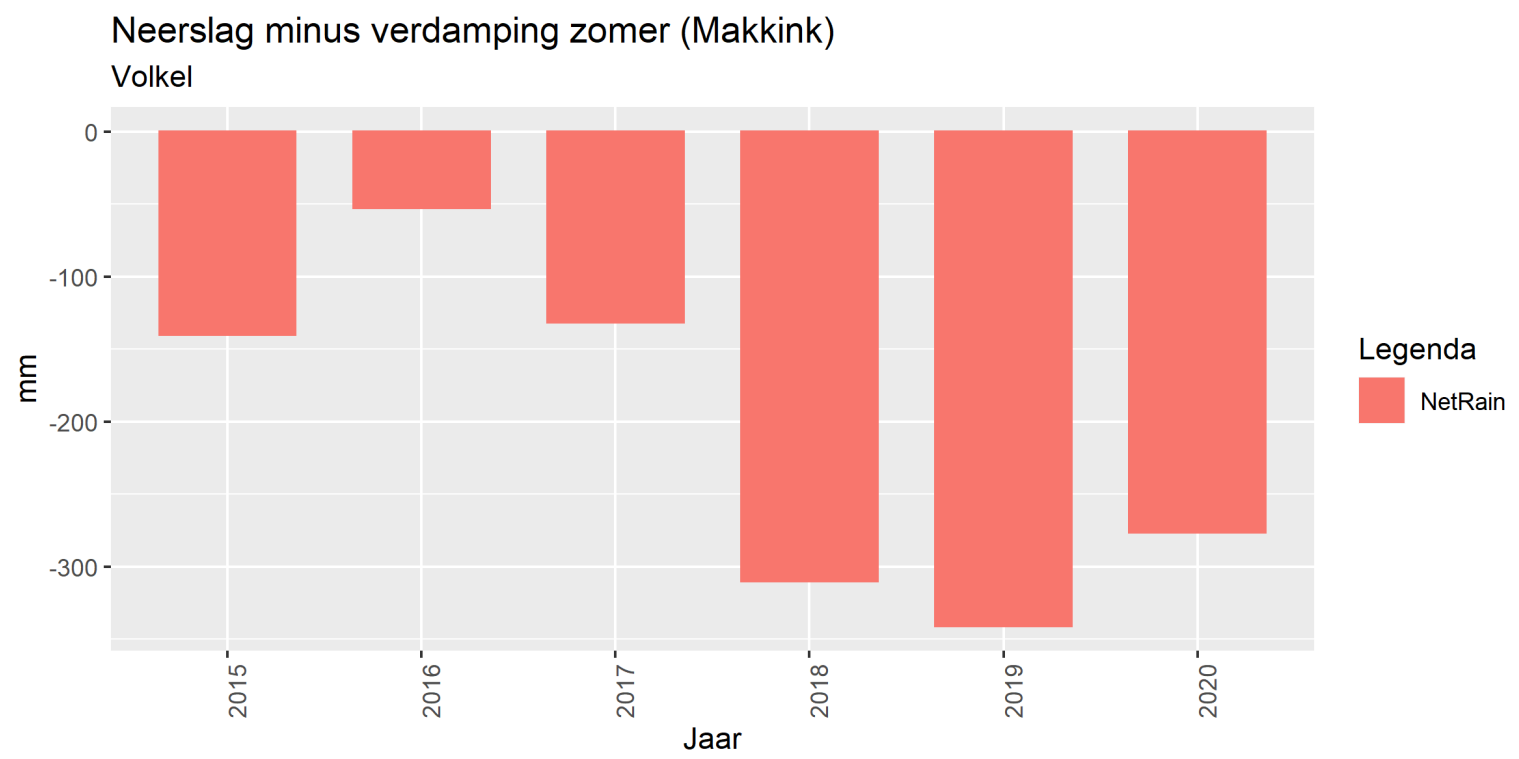

Figuur B8.2 Netto neerslag zomerperiode (1 april-1 oktober) voor meteostation Volkel.

In Figuur B8.3 zijn voor 2020 de cumulatieve neerslaghoeveelheden van de verschillende databronnen weergegeven. Hieruit blijkt dat er behoorlijke verschillen aanwezig zijn, zowel in de jaarhoeveelheid als in het verloop door het jaar heen. 


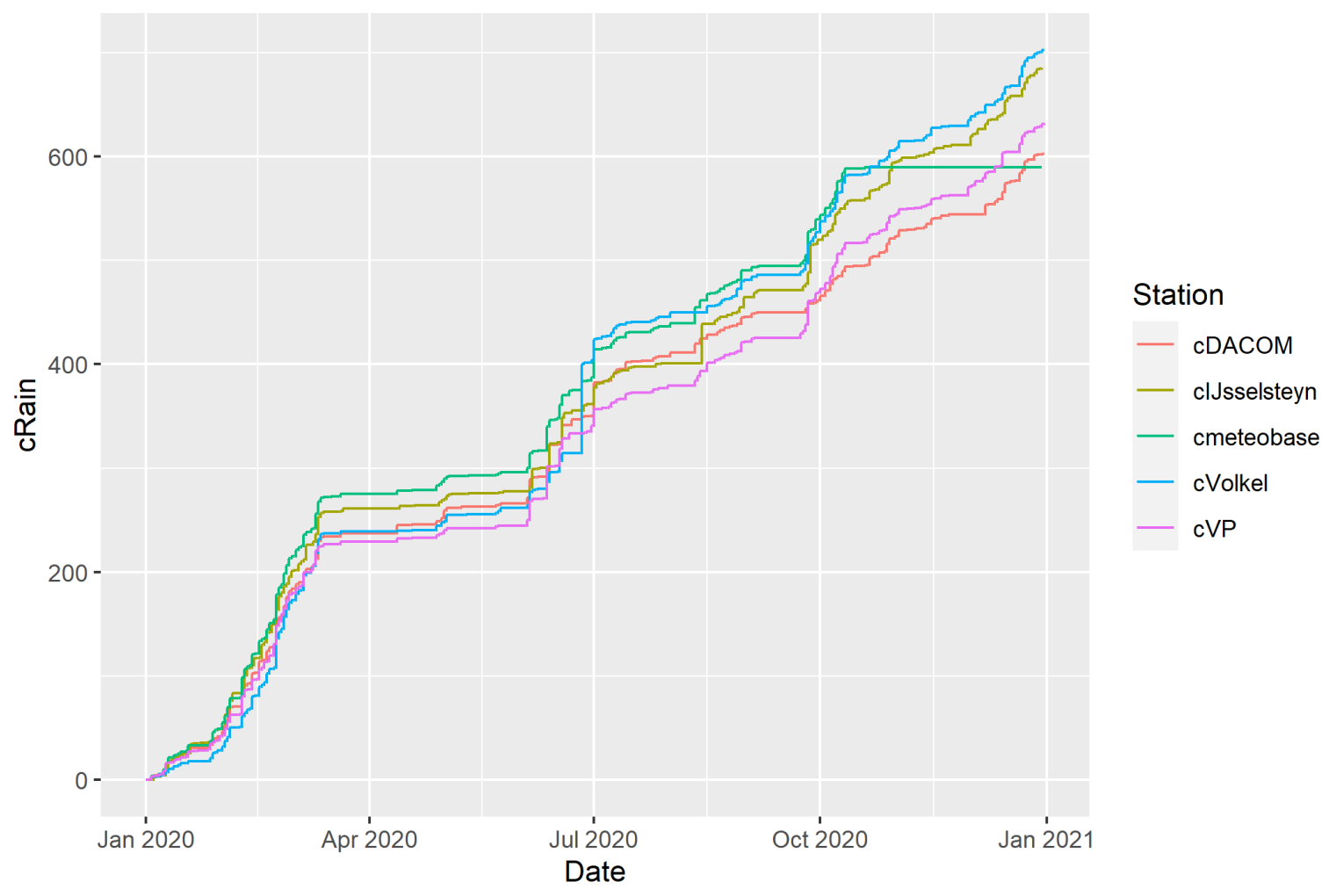

Figuur B8.3 Cumulatieve neerslag van de verschillende bronnen voor 2020. 


\section{Bijlage 9 Lithologie Vredepeel}
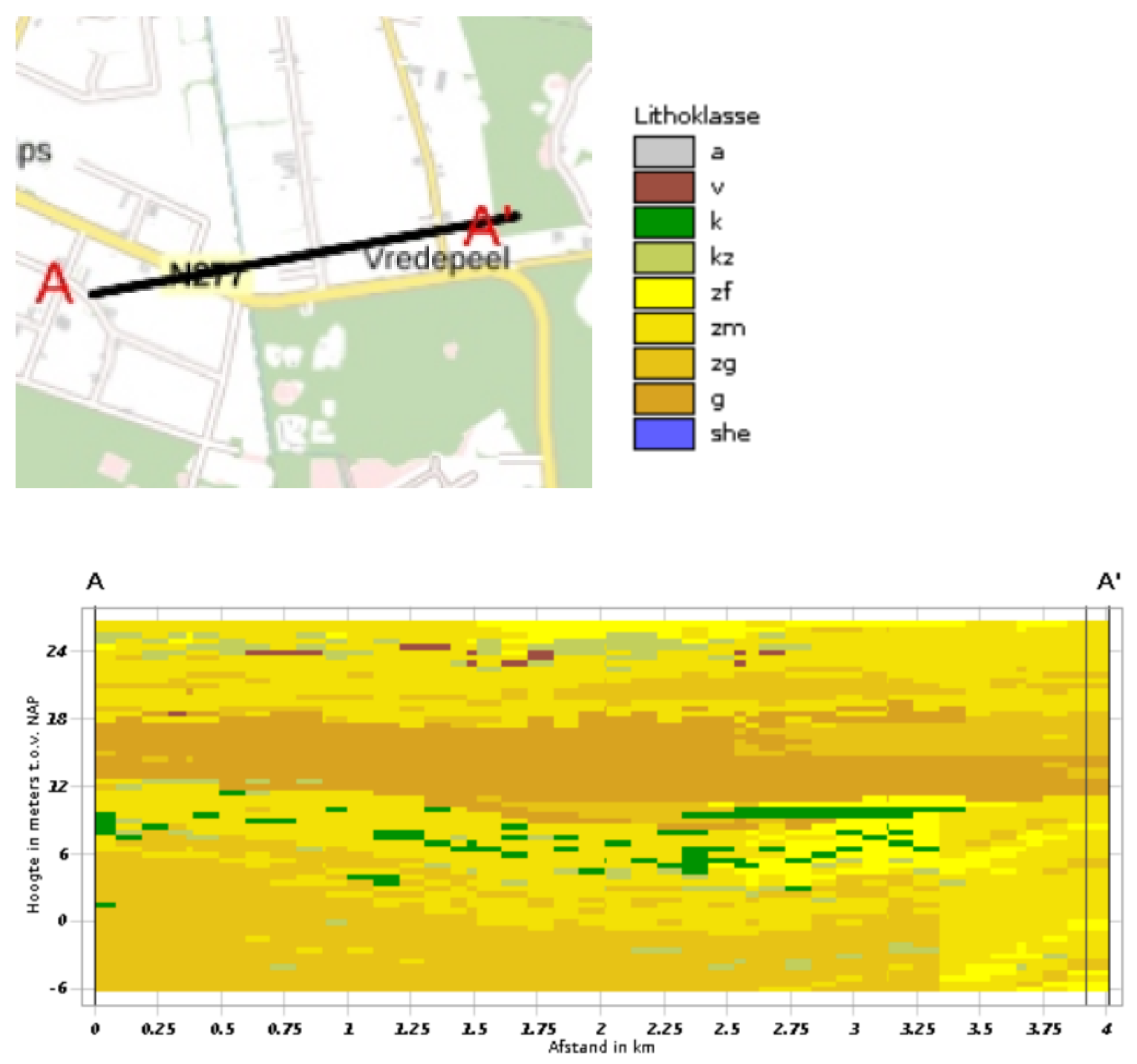

Figuur B9.1 Dwarsdoorsnede bodemopbouw tot circa 30 m-mv (Dinoloket) in Vredepeel. 


\section{Bijlage 10 Gewasontwikkeling Groenmonitor Vredepeel}

De Groenmonitor geeft informatie over de ontwikkeling van gewassen. Onderstaande tabel geeft de betekenis van de verschillende codes weer, waarbij een waarde de stand van het gewas/vegetatie weergeeft. In de figuren daaronder staat de ontwikkeling van de gewassen voor de jaren $2018 \mathrm{t} / \mathrm{m}$ 2020.

Tabel B10.1 Betekenis NDVI-scores.

\begin{tabular}{|c|c|c|}
\hline NDVI & Landbouw & Natuur \\
\hline 0 & Open water & Open water \\
\hline 0.1 & Drassig/nat geploegd land & Wit zand of rotsachtige bodems (tevens stedelijk gebied en wegen) \\
\hline \multirow[t]{2}{*}{0.3} & Net opkomend gewas & Net geoogst gewas \\
\hline & & $\begin{array}{l}\text { Bladverliezende vegetatie in de winter, zoals loofbos, struweel, heide, } \\
\text { riet }\end{array}$ \\
\hline \multirow[t]{2}{*}{0.4} & Opkomend gewas & Gemaaid gras \\
\hline & & Naaldbos in de winter \\
\hline 0.5 & Gesloten gewas & Opkomende (lente) of afstervende (herfst) bladverliezende vegetatie \\
\hline \multirow[t]{2}{*}{0.6} & Gewas met \pm 2 bladlagen & Naaldbos in de zomer \\
\hline & Afgerijpte mais & Heide in volle bloei \\
\hline \multirow[t]{4}{*}{ hoger } & Groene volgroeide granen & \\
\hline & Lang gras & \\
\hline & Andere groene gewassen met veel & \\
\hline & bladlagen & \\
\hline
\end{tabular}




\section{Groenindex}

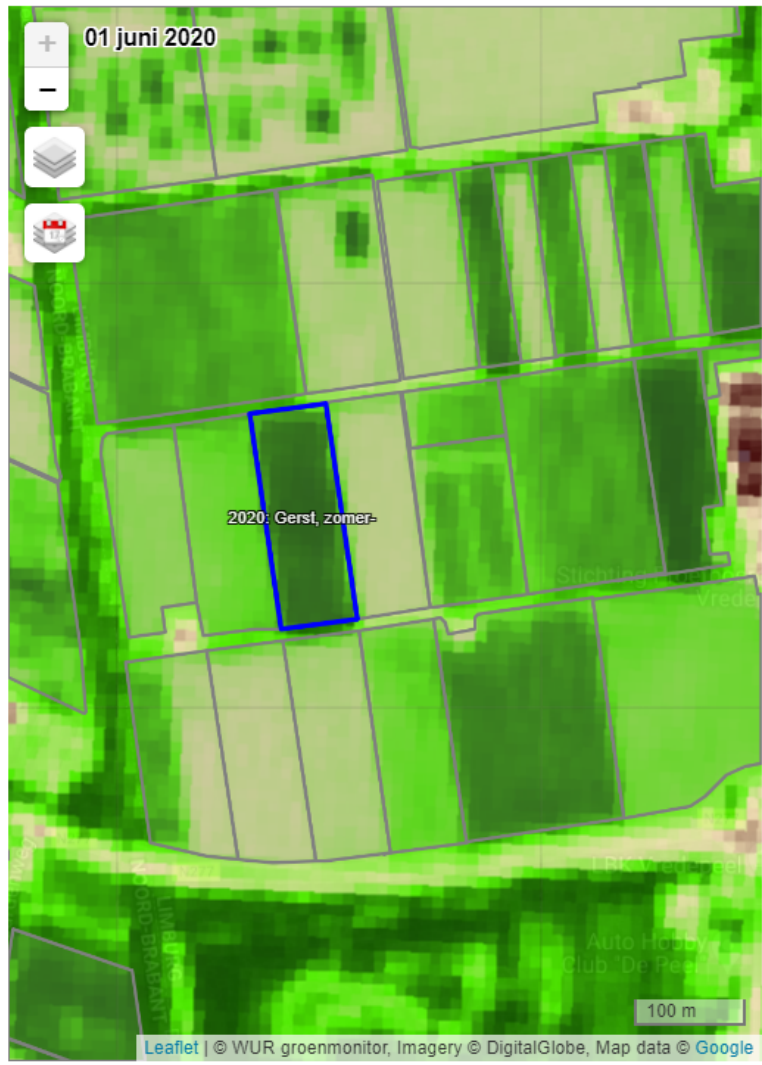

vredepeel

Legenda NDVI/WDV

\section{no data}

water $(\mathrm{NDV}|=0 ; \mathrm{WDV}|=0)$

urbaan, zand (NDVI = 0.02; WDVI $=0.02$ )

kale grond $(\mathrm{NDVI}=0.2 ; \mathrm{WDVl}=0.1)$

gesloten gewas $(\mathrm{NDVI}=0.6 ; \mathrm{WDVI}=0.2)$

meerdere bladlagen $(\mathrm{NDVI}=1.0 ; \mathrm{WDVI}=0.6$

Groenindex 2020 (NDVI)

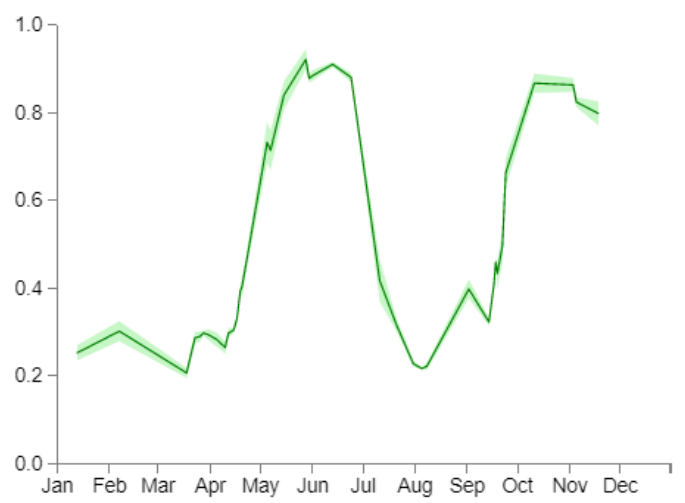

AgroDataCube is een initiatief van Wageningen UR en geeft toegang tot 'open data' rondom landbouw en voedsel. Klik hier voor achtergrondinformatie.

Figuur B10.1 NDVI-waarde perceel voor 2020.

\section{Groenindex}

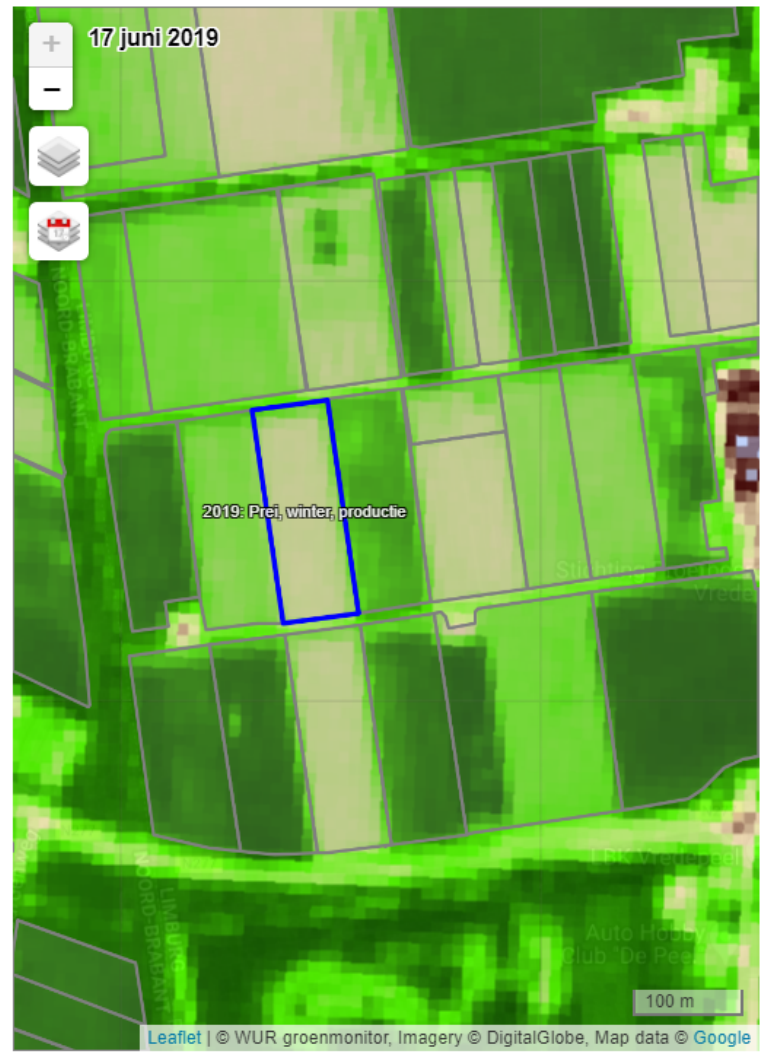

vredepeel

Legenda NDVI/wDVI

\section{no data}

water $(\mathrm{NDVI}=0 ; \mathrm{WDVI}=0)$

urbaan, zand $(\mathrm{NDVI}=0.02 ; \mathrm{WDVI}=0.02$

kale grond $(\mathrm{NDVI}=0.2 ; \mathrm{WDVI}=0.1)$

gesloten gewas $(\mathrm{NDVI}=0.6 ; \mathrm{WDVl}=0.2$

meerdere bladlagen $(\mathrm{NDVI}=1.0 ; \mathrm{WDVI}=0.6$

Groenindex 2019 (NDVI)

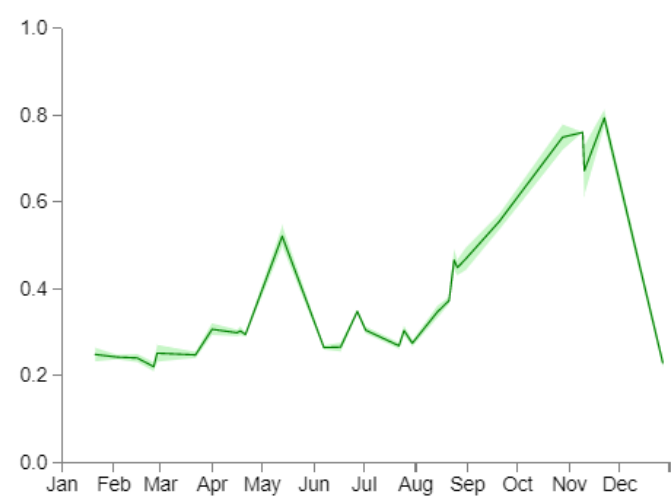

AqroDataCube is een initiatief van Wageningen UR en qeeft toegang tot 'open data' .

Figuur B10.2 NDVI-waarde perceel voor 2019. 


\section{Groenindex}

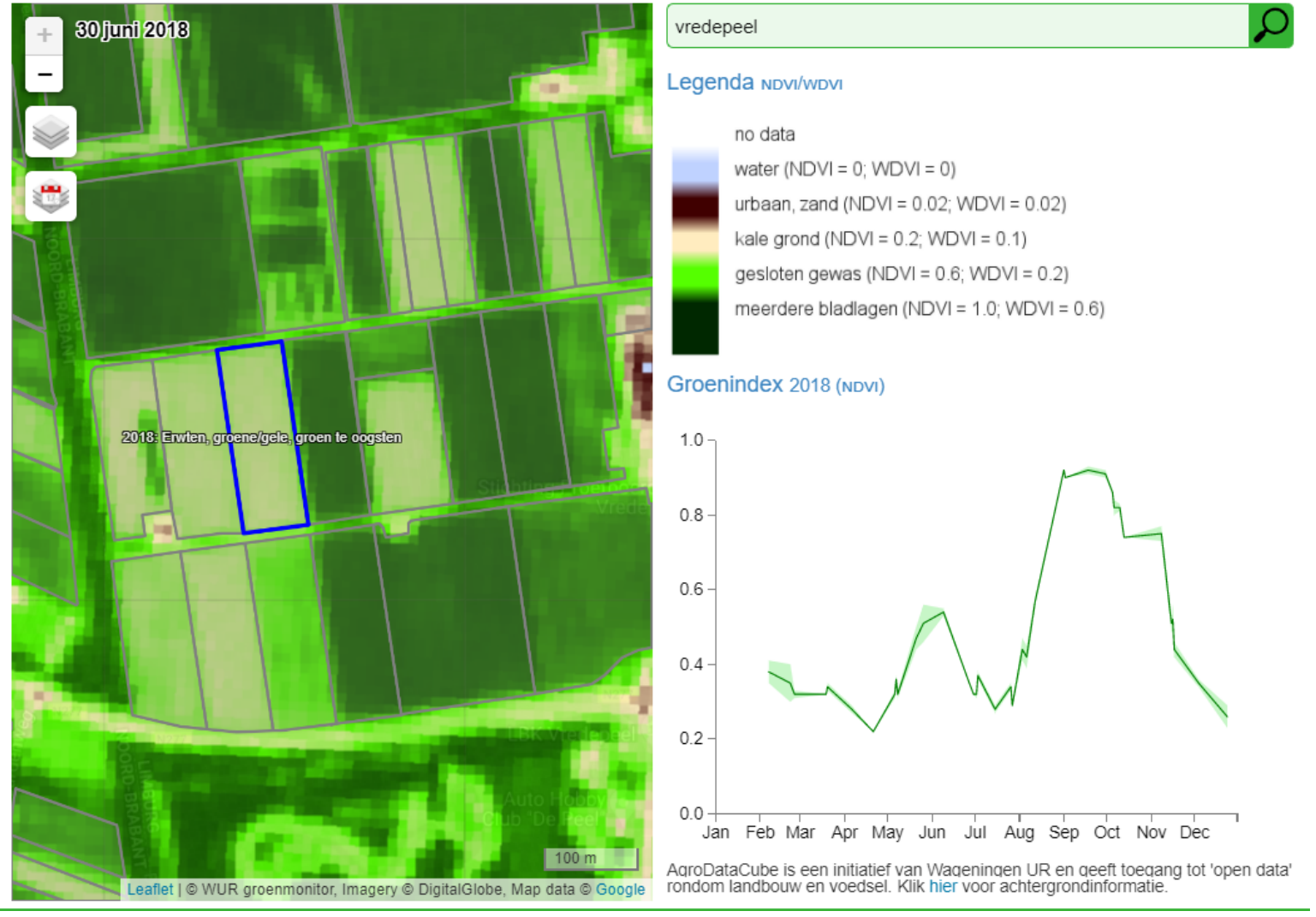

Figuur B10.3 NDVI-waarde perceel voor 2018. 


\section{Bijlage 11 Metingen tensiometers Vredepeel}

In Figuur B11.1 zijn de gemeten drukhoogten weergegeven. Hierbij valt het volgende op:

- Beregening:

- De beregeningen op 8 en 17 mei zijn ( 8 mei vertraagd reagerend) herkenbaar in de meetreeksen. Volgens de beheerder van Vredepeel is steeds $27 \mathrm{~mm}$ beregend. Voor 8 mei is met de lokaal geïnstalleerde tipping bucket circa $9 \mathrm{~mm}$ gemeten, voor 17 mei meet de tipping bucket $17 \mathrm{~mm}$ en voor 28 mei is er geen beregening gemeten.

De tipping bucket-waarden zijn daarom voor de gehele onderzoeksperiode als niet-betrouwbaar aangemerkt.

- Plot 40:

- De meting op een diepte van $17 \mathrm{~cm}$-mv toont een drukhoogte $<1 \mathrm{~cm}$ vanaf begin juni tot circa eind juni. Dat duidt op een erg natte bovengrond, wat niet logisch is voor deze periode (er heeft ook geen beregening plaatsgevonden). Tensiometers kunnen niet lager meten dan ca. $-1000 \mathrm{~cm}$ waterdruk (= -1 bar), omdat er dan lucht in de tensiometer komt. In de praktijk is deze limiet iets hoger, namelijk circa $-900 \mathrm{~cm}$ waterdruk bij goed watergevulde tensiometers. Als er lucht in de tensiometer zit (deze is dan 'doorgeslagen'), is deze niet meer betrouwbaar. De onbetrouwbare waarden zijn daarom verwijderd uit de dataset.

- De metingen op diepten van 46 en 64 cm -mv geven een beperkte drukhoogte (weinig negatief). Dat kan zodra de grondwaterstand niet al te diep wegzakt en de vochtonttrekking door de wortels op die diepte beperkt is.

- Plot 48:

- De drukhoogten zijn op een diepte van $17 \mathrm{~cm}$-mv zijn gedurende de hele periode vaak kleiner dan $-250 \mathrm{~cm}$ (droger). Dat ligt in de lijn der verwachting op deze diepte.

- De metingen op $41 \mathrm{~cm}$-mv komen voor een deel van de periode met elkaar overeen, maar geven ook een duidelijk verschil gedurende de periode half juni $t / m$ begin juli. Begin juni zijn de drukhoogten kleiner geweest dan $-900 \mathrm{~cm}$, waardoor de tensiometer is doorgeslagen en de metingen na deze datum als niet betrouwbaar moeten worden aangemerkt. Omdat de bodemlaag op $41 \mathrm{~cm}$ begin juni al sterk uitgedroogd was, moet de gehele bouwvoor tot onderin al sterk zijn uitgedroogd. De sterke uitdroging op $41 \mathrm{~cm}$ diepte in combinatie met een relatief ruime groei duidt erop dat er wortels in de ondergrond moeten zijn gedrongen.

De gemeten drukhoogten zijn gebruikt bij de kalibratie en validatie van het SWAP-model. 


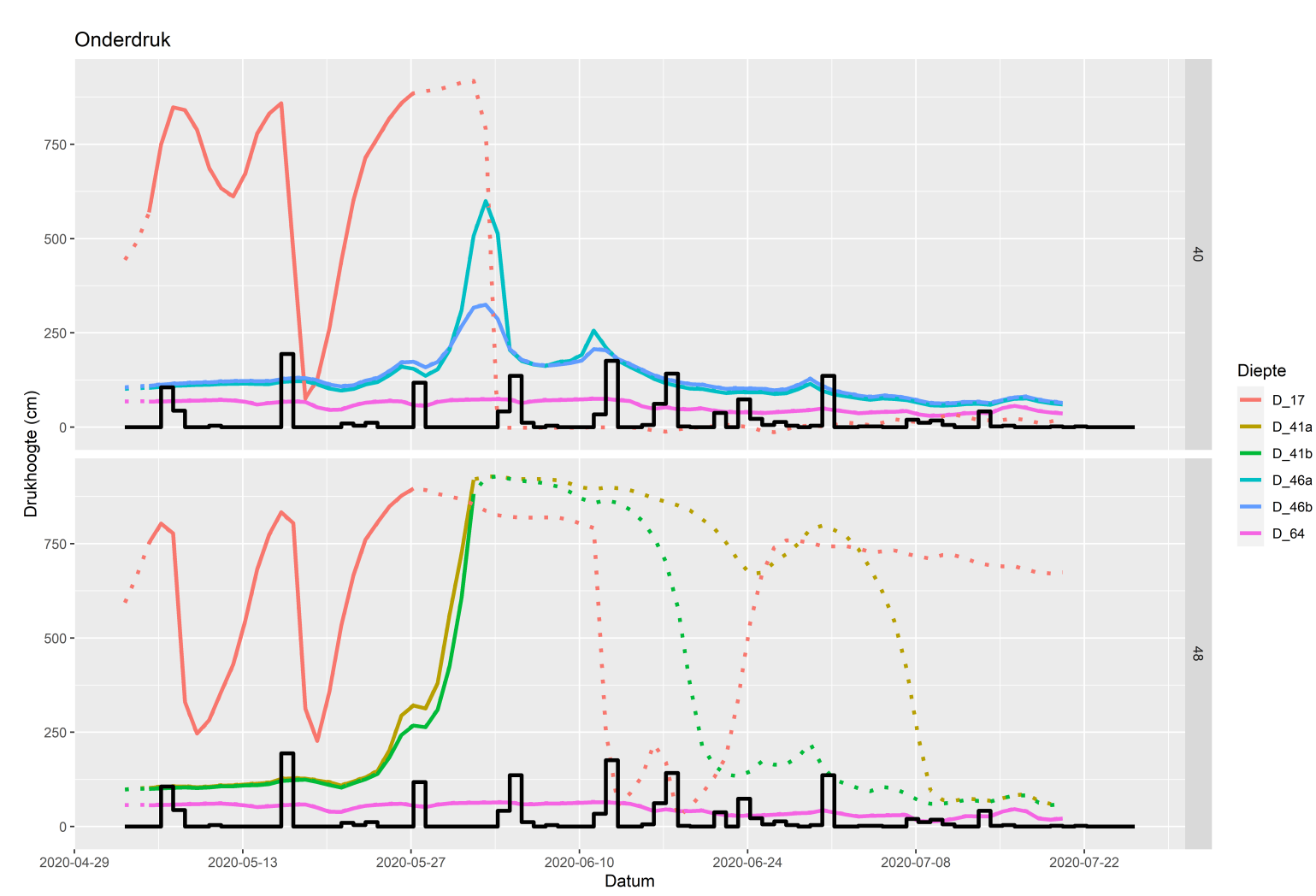

Figuur B11.1 Tensiometerdata plots 40 en 48 op verschillende diepten (in zwart is het neerslagpatroon weergegeven met op 17 mei 2020 een neerslag van 17 mm, gemeten met tipping bucket). Gestippeld zijn de metingen na het 'doorslaan' van de tensiometers, deze metingen zijn niet betrouwbaar. 


\section{Bijlage 12 Opbrengsten Vredepeel}

In Figuur B12.1 zijn de opbrengsten in 2020 zoals gemeten door het proefbedrijf voor de plots gegeven. De plots $27.1 \mathrm{a}$ en b geven een groot verschil in gemeten opbrengsten: 6.0 ton/ha voor NKG15 en 8,2 ton/ha voor Ploeg30.

De andere geploegde percelen geven in 2020 een grote spreiding in opbrengsten (5.4-8.3 t/ha). De opbrengsten zijn, behalve door grondbewerking, ook onderhevig aan andere externe factoren. Een nadere analyse toont aan dat stuifzand begin april 2020 voor aanzienlijke schade heeft gezorgd, met name op plot 27.1a. Dit is geverifieerd aan de hand van een luchtfoto. De jonge plantjes raakten bedolven en hadden daardoor een slechte start. Op 24 april heeft er een telling van het aantal plantjes plaatsgevonden. Op 27.1a waren 2.700 plantjes/ha geteld (92\% opkomst) en op $27.1 \mathrm{~b}$ 2975 plantjes/ha (100\% opkomst). De gemeten opbrengstverschillen worden daarom voornamelijk aan stuifzandschade toegekend en zijn daarmee moeilijk te vergelijken met de opbrengsten die in de SWAP-berekeningen worden gepresenteerd.

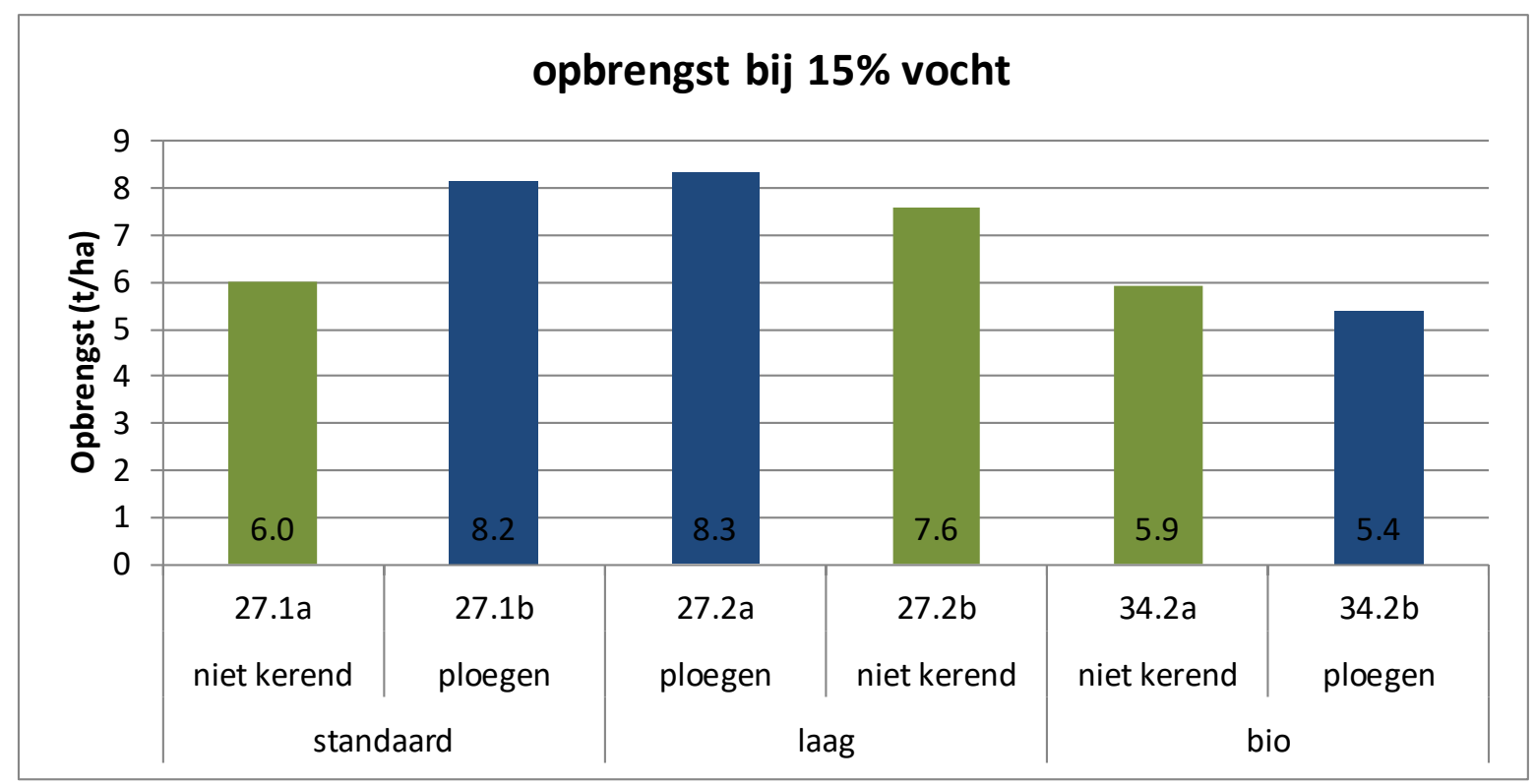

Figuur B12.1 Opbrengsten zomergerst in 2020 (blauw: Ploeg30, groen: NKG15).

Over de jaren heen variëren de opbrengsten aanzienlijk (zie Figuur B12.2 en Figuur B12.3). In deze figuren is te zien dat de opbrengst bij 'Biologisch NKG' vanaf 2015 de opbrengsten van de andere bewerkingen benadert. Het is bekend dat NKG enige tijd nodig heeft om zich in te stellen (aanpassing bodemleven). Interessant is om te zien dat de combinatie Biologisch en Ploegen het slechter doet dan Biologisch en NKG. 


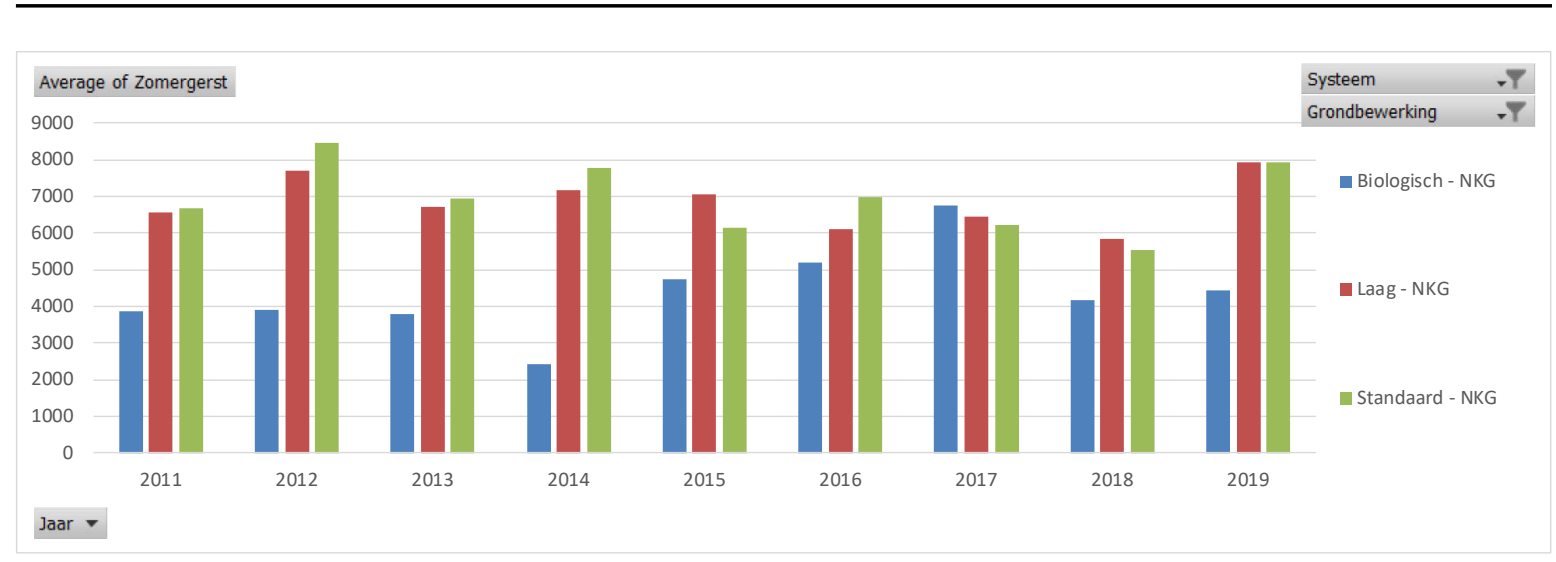

Figuur B12.2 Opbrengsten NKG zomergerst (kg/ha) in 2011-2019.

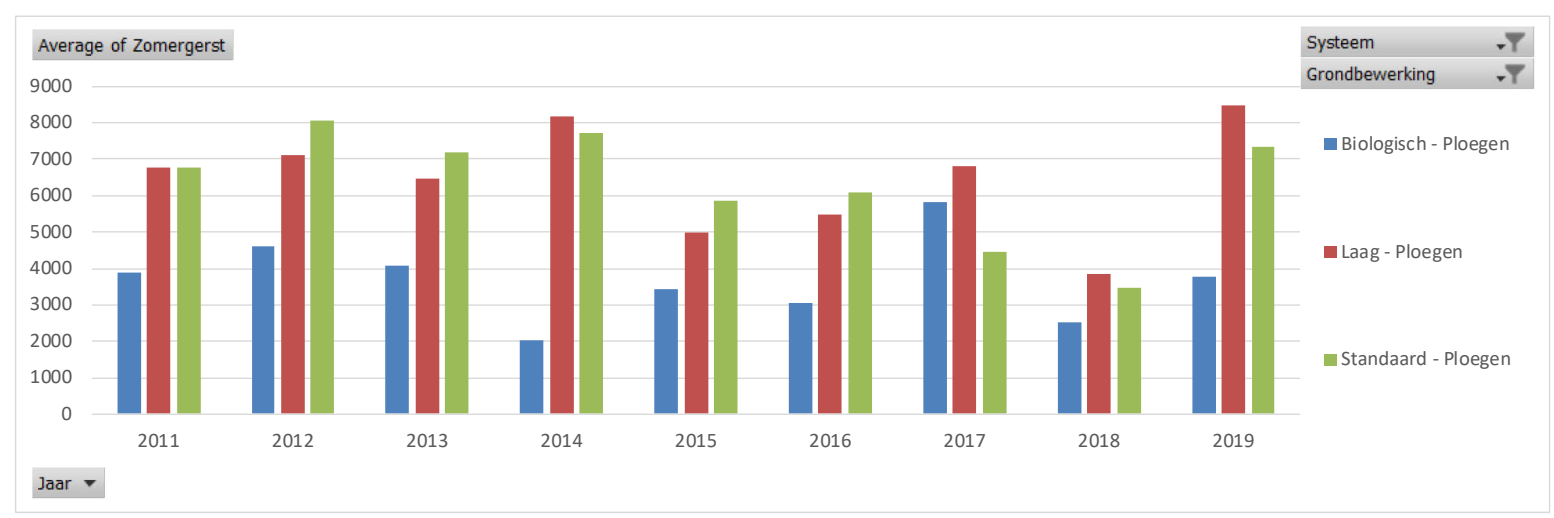

Figuur B12.3 Opbrengsten Ploegen zomergerst (kg/ha) in 2011-2019.

Tabel B12.1 Opbrengsten per plot (gemiddelden en standaarddeviatie periode 2015-2019).

\begin{tabular}{lll} 
Bewerking & Average of Zomergerst & Std Dev of Zomergerst \\
Biologisch & 4396 & 1287 \\
\hline Laag & 6301 & 1370 \\
\hline Standaard & 6005 & 1319 \\
\hline
\end{tabular}

Tabel B12.2 Opbrengsten per plot (gemiddelden en standaarddeviatie periode 2015-2019).

\begin{tabular}{lll} 
Grondbewerking & Average of Zomergerst & Std Dev of Zomergerst \\
NKG & 6105 & 1146 \\
\hline Ploegen & 5501 & 1744 \\
\hline
\end{tabular}




\section{Bijlage 13 SWAP-modelcheck Lelystad}

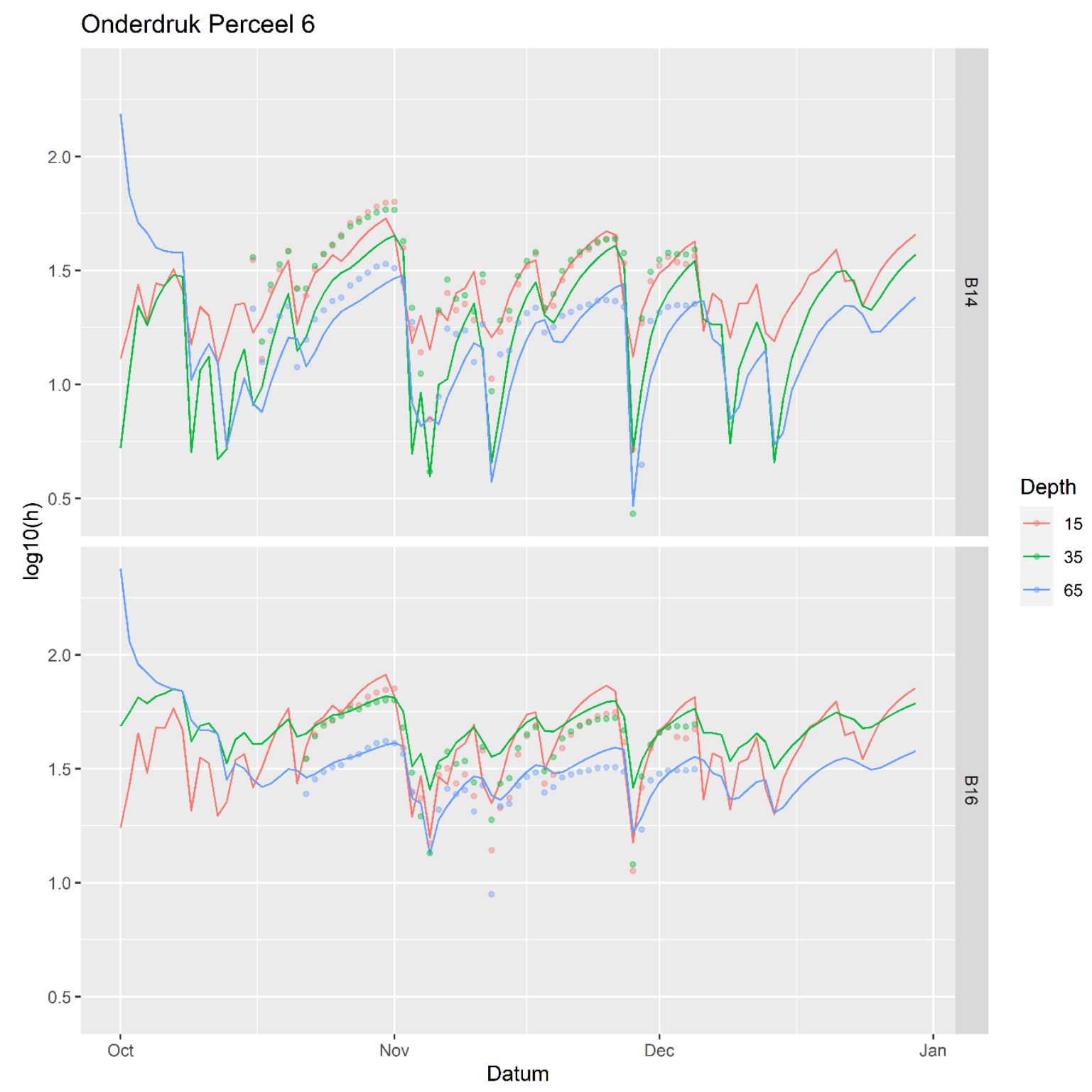

Figuur B13.1 Vergelijking metingen met modelresultaten voor blok 14 en 16. 


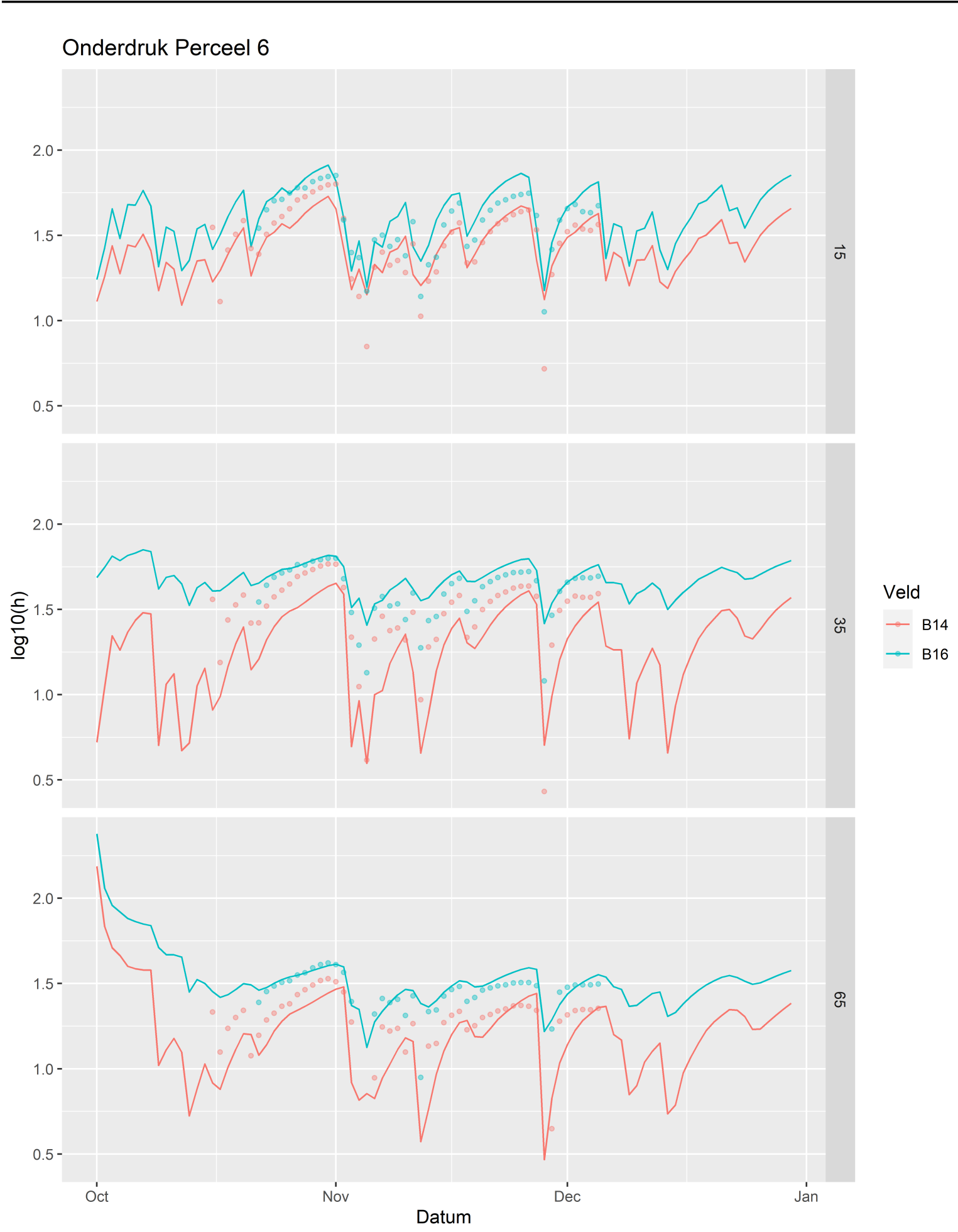

Figuur B13.2 Vergelijking drukhoogtemetingen met modelresultaten voor blok 14 en 16 (bovenste figuur voor $15 \mathrm{~cm}-m v$, middelste voor $35 \mathrm{~cm}-m v$, onderste $65 \mathrm{~cm}-\mathrm{mv}$ ). 
Wageningen Environmental Research Postbus 47

6700 AA Wageningen

T 0317480700

www.wur.nl/environmental-research

Wageningen Environmental Research

Rapport 3109

ISSN 1566-7197
De missie van Wageningen University \& Research is 'To explore the potential of nature to improve the quality of life'. Binnen Wageningen University \& Research bundelen Wageningen University en gespecialiseerde onderzoeksinstituten van Stichting Wageningen Research hun krachten om bij te dragen aan de oplossing van belangrijke vragen in het domein van gezonde voeding en leefomgeving. Met ongeveer 30 vestigingen, 6.800 medewerkers ( $6.000 \mathrm{fte}$ ) en 12.900 studenten behoort Wageningen University \& Research wereldwijd tot de aansprekende kennisinstellingen binnen haar domein. De integrale benadering van de vraagstukken en de samenwerking tussen verschillende disciplines vormen het hart van de unieke Wageningen aanpak. 


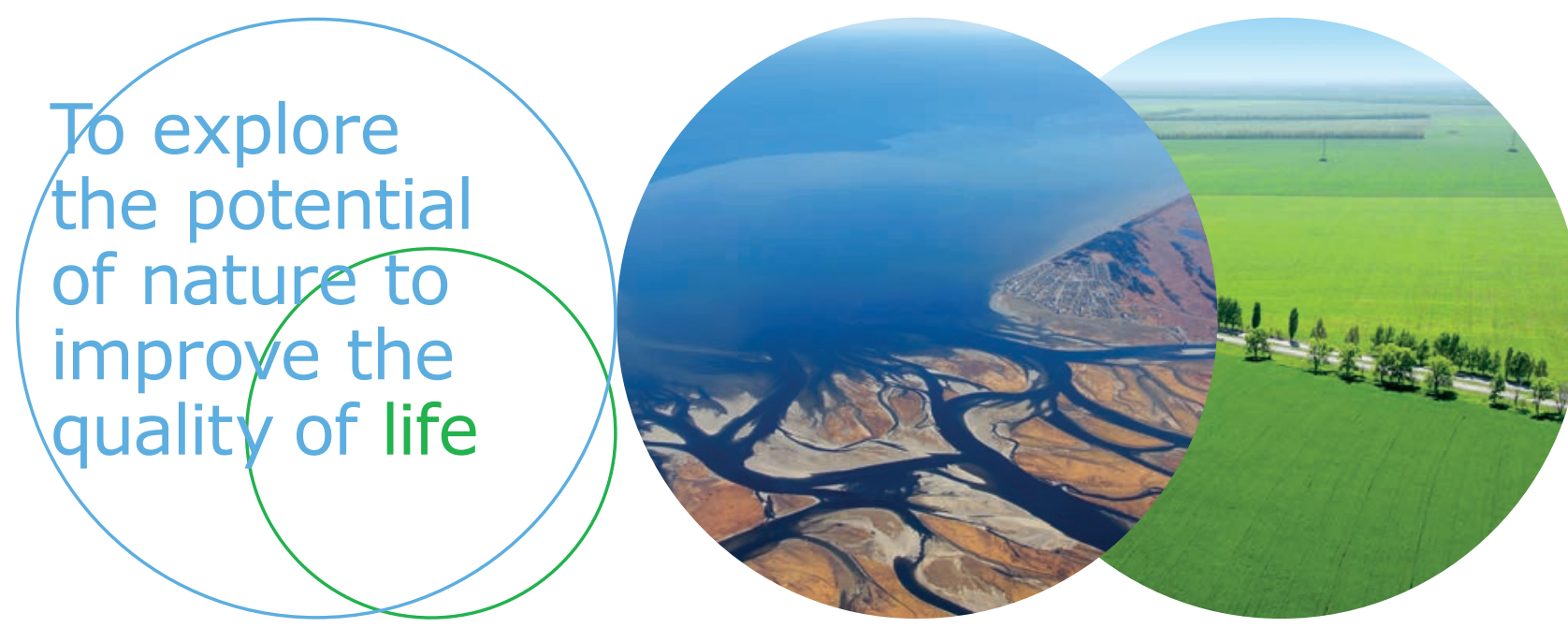

Wageningen Environmental Research Postbus 47

$6700 \mathrm{AB}$ Wageningen

T 317480700

www.wur.nl/environmental-research

Rapport 3109

ISSN 1566-7197
De missie van Wageningen University \& Research is 'To explore the potential of nature to improve the quality of life'. Binnen Wageningen University \& Research bundelen Wageningen University en gespecialiseerde onderzoeksinstituten van Stichting Wageningen Research hun krachten om bij te dragen aan de oplossing van belangrijke vragen in het domein van gezonde voeding en leefomgeving. Met ongeveer 30 vestigingen, 6.800 medewerkers (6.000 fte) en 12.900 studenten behoort Wageningen University \& Research wereldwijd tot de aansprekende kennisinstellingen binnen haar domein. De integrale benadering van de vraagstukken en de samenwerking tussen verschillende disciplines vormen het hart van de unieke Wageningen aanpak. 